UNIVERSIDADE DE SÃO PAULO

FACULDADE DE ZOOTECNIA E ENGENHARIA DE ALIMENTOS

ROBERTA SOMMAVILLA

Interação humano-animal na produção de suínos 


\title{
ROBERTA SOMMAVILLA
}

\section{Interação humano-animal na produção de suínos}

\author{
Versão Corrigida
}

\author{
Tese apresentada à Faculdade de \\ Zootecnia e Engenharia de \\ Alimentos da Universidade de São \\ Paulo, como parte dos requisitos \\ para obtenção do Título de Doutor \\ em Ciências. \\ Área de Concentração: Qualidade \\ e Produtividade Animal. \\ Orientador: Evaldo Antonio \\ Lencioni Titto \\ Coorientadora: Maria José Hötzel
}


Dados Internacionais de Catalogação na Publicação

Serviço de Biblioteca e Informação da Faculdade de Zootecnia e Engenharia de Alimentos da Universidade de São Paulo

Sommavilla, Roberta

S697i

Interação humano-animal na produção de suínos /

Roberta Sommavilla. -- Pirassununga, 2015.

$111 \mathrm{f}$.

Tese (Doutorado) -- Faculdade de Zootecnia e

Engenharia de Alimentos - Universidade de São Paulo. Departamento de Ciências Básicas.

Área de Concentração: Qualidade e Produtividade Animal.

Orientador: Prof. Dr. Evaldo Antonio Lencioni Titto.

1. Bem-estar animal 2. Enriquecimento ambiental

3. Etologia 4. Qualidade de carne 5. Tratamento

aversivo. I. Título. 


\section{DEDICO...}

Aos meus pais Claudia e Ivan

Ao meu irmão Andrey

Eu nada seria sem o amor incondicional, os exemplos e o apoio de vocês 


\section{AGRADECIMENTOS}

À minha família, meu alicerce, que nunca duvidou do meu potencial e sempre me apoiou em todas as decisões: minha mãe Claudia Maria Floriani, meu pai Ivan Luis Sommavilla (mais do que in memoriam, dentro do meu coração aonde quer que eu vá), meu irmão Andrey Sommavilla e minha cunhada Aline Coldebella Sommavilla. Aos meus avós Afonso, Dalva e Vitória pelas bênçãos, incentivo, amor e suas carinhas de "volte logo" a cada partida minha. A todos os meus tios e tias, primos e primas. Vocês são parte de todas as minhas conquistas.

Aos meus orientadores Evaldo Antonio Lencioni Titto e Maria José Hötzel pelos puxões de orelha e pelas palavras de amizade que sempre vieram na hora certa.

À professora Cristiane Gonçalvez Titto, que sempre esteve à disposição, sempre com um sorriso no rosto e, sem a qual, eu certamente não teria terminado este trabalho.

Aos meus amigos do LABE: Ana, Denis, Fabio, Henrique, Qui, Tata, Thuany, pela companhia diária, risadas e cafés. Especialmente à Lina e à Zica que ajudaram firmemente todos os dias do experimento.

Aos meus amigos do LETA, Clarisse Cardoso e Ruan Daros, pela força e ajuda.

Aos meus amigos do Canadá: Danyel, Douglas, Filipe, Inês, Lu, Marina, Marcos, Marjo, Sabine, Simon, Sophie e a Maison Jaune que estiveram do meu lado no momento em que eu precisava de amigos de verdade e eu os tive! Especialmente à Sophie Horth (turn around...), ao Nicolas Devillers e ao Luigi Faucitano que são grandes mestres para mim.

Aos meus amigos que me suportaram do início ao fim: Alemoa e Laura; as Divas de SC; Aurea, Baleia e Rep. SokaZando; Luiz Fernet; Moana; Lívia Maria; as gurias do Studio A, Daia, Jorge e Cla, e a todas as cervejas que bebemos juntos.

Aos funcionários e acadêmicos da Suinocultura Experimental, especialmente ao Professor Anibal Moretti por ceder as instalações da granja para o experimento.

À Fundação de Amparo e Pesquisa do Estado de São Paulo (FAPESP) pela concessão da Bolsa de Pesquisa no País, Bolsa Estágio de Pesquisa no Exterior e o Auxílio Pesquisa, sem os quais a realização deste trabalho seria prejudicada.

Ao Colégio Sigma, à Universidade do Estado de Santa Catarina, à Universidade Federal de Santa Catarina, à University of British Columbia, à Universidade de São Paulo, à Agriculture and Agri-Food Canadá, que fazem parte da minha história e ajudaram a construir quem eu sou.

A todas as pessoas que passaram pela minha vida e que, de uma forma ou de outra, contribuíram para que eu chegasse aqui. 
Primeiro foi preciso civilizar o homem em sua relação com o próprio homem. Agora é preciso civilizar o homem em sua relação com a natureza e com os animais.

(Victor Hugo) 


\section{RESUMO}

SOMMAVILLA, R. Interação humano-animal na produção de suínos. 111f. Tese (Doutorado) - Faculdade de Zootecnia e Engenharia de Alimentos, Universidade de São Paulo, Pirassununga, 2015.

Objetivou-se comparar os parâmetros comportamentais indicativos de estresse, a qualidade da carne e a influência do enriquecimento ambiental em leitões criados no sistema intensivo confinado, de acordo com a qualidade dos tratamentos recebidos. Para isso, foram utilizados 144 leitões divididos em três grupos que receberam tratamentos distintos: 1) Tratamento Aversivo (TA): pessoa se dirigia aos leitões de forma rude, utilizando tom de voz agressivo e fazendo ameaças posturais; 2) Tratamento Controle (TC): pessoa foi cuidadosa ao se movimentar e usou tom de voz suave; 3) Tratamento Misto (TM): os animais receberam TA durante as fases de maternidade e creche e TC durante as fases de crescimento e terminação. Após o desmame, os leitões foram submetidos a testes para aferir medo e verificar se conseguiam reconhecer seu tratador habitual. Foram observados os comportamentos nas mudanças de ambiente, através de instantâneos de 5 min. Na fase de crescimento/terminação, metade dos animais recebeu enriquecimento ambiental. Após o abate foi realizada a análise da qualidade da carne com relação ao seu $\mathrm{pH}$, temperatura, coloração, perda de água por cocção e exsudação. Variáveis como cortisol, lactato, creatinafosfoquinase, ganho de peso, conversão alimentar e consumo de ração também foram aferidas. $O$ delineamento experimental foi inteiramente casualizado e para a análise dos dados foi utilizado o procedimento PROC MIXED e GLM do programa estatístico SAS. Leitões que receberam tratamento aversivo apresentaram maior frequência de interações agonísticas na maternidade $(P=0,01)$, creche $(P=0,04)$, crescimento/terminação $(P=0,0002)$ e no pré-abate $(P=0,06)$; além de apresentarem maior frequência de belly-nosing no pósdesmame $(P=0,001)$, maior atividade nos testes de medo $(P=0,01)$, menor tempo $(P=0,03)$ e menor frequência $(P=0,005)$ de contato com o novo objeto. Animais que receberam enriquecimento ambiental apresentaram maior frequência do comportamento exploratório $(P=0,01)$. Não houve diferença no ganho de peso, nas análises de qualidade de carne e de sangue $(P>0,05)$, exceto para lactato que apresentou concentrações mais elevadas para animais tratados de forma aversiva $(P<0,05)$. Leitões tratados de forma aversiva demonstraram um padrão comportamental indicando o elevado estresse. A simples cessação deste tratamento não parece ser suficiente para que os animais retomem o padrão comportamental comum à espécie, indicando um efeito residual do tratamento recebido anteriormente. Além disso, estes animais são mais medrosos à novidade, ao isolamento social e ao tratador aversivo. Mesmo não havendo diferença de desempenho e qualidade de carne, estes resultados indicam um empobrecimento do bem-estar desses animais. Por outro lado, quando cessado o tratamento aversivo e adicionado o enriquecimento ambiental, os efeitos residuais do estresse sofrido nas primeiras fases de vida foram suprimidos e os animais apresentaram uma melhoria na resposta ao estresse e no seu bemestar.

Palavras-chave: bem-estar animal, enriquecimento ambiental, etologia, qualidade de carne, tratamento aversivo 


\begin{abstract}
SOMMAVILLA, R. Human-animal interaction on pig production. 111f. Tese (Doutorado) Faculdade de Zootecnia e Engenharia de Alimentos, Universidade de São Paulo, Pirassununga, 2015.
\end{abstract}

The aim of this work was to compare the behavioral parameters indicative of stress, meat quality and the influence of enrichment in pigs housed in intensive confined system, according to the quality of the treatment received. For this, 144 piglets were separated in three groups with different treatment: 1) Aversive (TA): the person responsible for the treatment was rude with the animals, used an aggressive tone of voice and moved harshly and unpredictably; 2) Control (TC): the person responsible for this treatment was careful to move around as was using a soft tone of voice; 3) Mixed (TM): the animals received TA during farrowing room and nursery, and with TC during growing and finishing phase. After weaning, piglets were tested to assess fear and if they could recognize its usual handler. Behavioral time budgets at each change of phase, was registered by scan sampling every 5min. In the growing-finishing phase half of the animals received environmental enrichment. After slaughter, meat quality was analysed in relation to their $\mathrm{pH}$, temperature, colour, drip loss, water holding capacity e tenderness. Variables such as cortisol, creatine phosphokinase, weight gain, feed conversion and consumption of solid food were also assessed. The experimental design was randomized and to analyse the data, we used PROC MIXED and GLM procedure of SAS statistical program. Animals TA had more frequency of agonistics interactions at farrowing room $(P=0.01)$, nursery $(P=0.04)$, growing/finishing phase $(P=0.0002)$ and at the day before the slaughter $(P=0.06)$; in addition they had higher frequency of belly-nosing after weaning $(P=0.001)$, higher activity on fear tests $(P=0.01)$, lower time $(P=0.03)$ and lower frequency $(P=0.005)$ of a contact with the novel object. Animal that received environmental enrichment showed more frequency of exploratory behaviour ( $P=0.01$ ). No difference was found on weight gain, meat quality and blood analysis $(P>0.05)$, but to lactate that was higher to aversive treatment animals $(P<0.05)$. Piglets that received an aversive treatment showed behavioral patterns indicative of higher stress. Finishing the aversive treatment was not enough to this animal restoring their behavioral pattern, indicating a residual effect of the aversive treatment. In addition, these animals were more fearful to novelty, social isolation and the aversive handling. Although there is no difference in performance and meat quality, the results show a poor animal welfare. In other hand, when the treatment was finished and an environmental enrichment was introduced, the residual effect of stress of the farrowing room and nursery were supressed and piglets showed an improvement of behavioral pattern and animal welfare.

Keywords: animal welfare, aversive handling, environmental enrichment, ethology, meat quality 


\section{LISTA DE FIGURAS}

Figura 1 - Modelo de relação humano-animal proposto por Hemsworth e Coleman em 1998

Figura 2 - Diagrama da resposta neuroendócrina ao estresse (adaptado de MATTERI; CARROLL; DYER, 2000). SNA: Sistema Nervoso Autônomo. C: Córtex da Glândula Adrenal. M: Medula da Glândula Adrenal. ACTH: Hormônio Adrenocorticotrófico. CRH: Hormônio liberador de corticotrofina

Figura 3 - Instalações da sala de maternidade

Figura 4 - Leitões sendo auxiliados para mamar o colostro

Figura 5 - Ração pré-inicial oferecida aos leitões a partir do 14을 dia de vida

Figura 6 - Instalações da sala de creche

Figura 7 - Instalação da sala de crescimento/terminação

Figura 8 - Esquema temporal de realização dos tratamentos. Durante as fases de creche e maternidade, os tratamentos foram realizados pela Pessoa 1 que sempre trajava macacão laranja. Durante a fase de crescimento/ terminação, os tratamentos foram realizados pela pessoa 1 (macacão laranja) para os grupos controle e aversivo, e pela pessoa 2 (macacão azul) para o grupo misto

Figura 9 - Esquerda: roupa laranja do tratador habitual do tratamento controle, tratamento aversivo e primeira fase do tratamento misto (aversivo). Direita: roupa azul do tratador habitual da segunda fase do tratamento misto (controle)

Figura 10 - Frequência relativa (média \pm erro padrão\%) dos comportamentos a) no comedouro, b) no bebedouro, c) interação agonística, d) tentativa de fuga e) belly-nosing, f) brincando, g) fuçando/explorando, h) repouso; observados durante a fase de creche nos leitões tratados de forma aversiva (marcador escuro) e controle (marcador claro). $\star: \mathrm{P}<0,05$ entre os tratamentos, no mesmo dia. UC: último dia de creche 
Figura 11 - Frequência relativa (média \pm erro padrão\%) dos comportamentos a) no comedouro, b) no bebedouro, c) interação agonística, d) tentativa de fuga e) brincando, f) fuçando/explorando, g) na lâmina d'água, h) repouso; observados durante os três primeiros dias da fase de crescimento nos leitões tratados de forma aversiva (marcador escuro), controle (marcador claro) e misto (marcador cinza). $\star: P<0,05$ entre tratamentos, no mesmo dia

Figura 12 - Área do Teste de Aproximação Humana com o tratador habitual esperando o leitão a ser testado (a), escore 1 (b) e escore 4 (c). Seta está demonstrando a linha de $0,5 \mathrm{~m}$ marcada no chão da área de teste.

Figura 13 - Animal durante o Teste de Área Desconhecida realizando o comportamento ativo/explorando (esquerda) e durante o Teste de Novo Objeto, interagindo com o objeto (direita)

Figura 14 - Médias de escores e erros padrão (\%) apresentadas nos dias 35 e 91 por leitões tratados de forma aversiva, mista e controle. Escore 1: leitão permitia ser tocado pela pessoa teste; escore 2: a pessoa conseguia se aproximar menos que $0,5 \mathrm{~m}$, mas o leitão se movia antes de ser tocado pela pessoa teste; escore 3: leitão se movimentava quando a pessoa chegava a 0,5 $\mathrm{m}$ de distância do mesmo. Leitão tentava fugir quando a pessoa estava há mais de $0,5 \mathrm{~m}$ de distância. $\star P<0,05$

Figura 15 - Média e erro padrão das frequências relativas das interações tratamento* dia dos comportamentos ativo e inativo, para os tratamentos controle e aversivo, no primeiro dia de observação (D1) e no segundo dia de observação (D2). $\star$ : $P<0,05$, para dia e tratamento.

Figura 16 - Eventos de vocalização durante os 5 minutos do Teste de Área Desconhecida

Figura 17 - Média e erro padrão das frequências relativas das interações tratamento*dia dos comportamentos: a) ativo, b) inativo, c) defecando; para os tratamentos controle (marcador claro) e aversivo (marcador escuro), nos primeiro dia de observação (D1) e no segundo dia de observação (D2). $\star: P<0,05$, para dia e tratamento

Figura 18 - Média e erro padrão das frequências relativas da interação tratamento*minuto do comportamento "atenção com o objeto", para os tratamentos controle (marcador claro) e aversivo (marcador escuro), nos trem minutos observados. $\star: \mathrm{P}<0,05$, entre tratamento

Figura 19 - Esquerda: baia de crescimento/terminação com enriquecimento de serragem e uvas passas; Direita: brinquedo feito com cano de PVC com orifícios por onde saiam as uvas passas que estavam no interior do brinquedo. 
Figura 20 - Frequência relativa (média e erro padrão) do comportamento "interação com o objeto" realizado por animais do tratamento controle, misto e aversivo. Letras diferentes demonstram diferença estatística $(P<0,05)$

Figura 21 - Uso do Lactate Scoult ${ }^{\circledR}$ para aferir lactato durante as pesagens

Figura 22 - a) caminhão utilizado para transportar os animais da granja para o abatedouro; b) animais na baia de espera no abatedouro

Figura 23 - Mensuração de espessura de toucinho (a) e área de olho de lombo (b).

Figura 24 - a) aferição de pH; b) cor; c) colheita de amostra para análise de perda de água por gotejamento

Figura 25 - Perda de água por cocção: a) amostra antes de assar; b) amostra dentro do forno de cozimento

Figura 26 - Maciez: a) retirada dos cilindros da amostra b) cilindros de amostra antes do cisalhamento; c) disposição dos cilindros dentro da amostra .........

Figura 27 - Média dos valores de lactato $\left(\mu \mathrm{Mol} . \mathrm{L}^{-1}\right)$ encontrado em leitões tratados de forma aversiva, mista e controle no dia do desmame, na mudança de sala da creche para a sala de crescimento/terminação, no dia pré-abate e no dia do abate 


\section{LISTA DE TABELAS}

Tabela 1 - Classificação da carne suína em Normal, PSE e DFD (adaptado de BRIDI, 2009)

Tabela 2 - Etograma de Trabalho: comportamentos observados durante as fases de maternidade $(M)$, creche $(C)$, crescimento/terminação $(C / T)$ e suas definições

Tabela 3 - Médias e erros padrão dos pesos $(\mathrm{kg})$ dos leitões que sofreram os tratamentos controle, misto ou aversivo, nas diferentes fases: ao nascimento, ao desmame, início da fase de crescimento, início da fase de terminação e dia pré-abate

Tabela 4 - Ganho de peso diário ( $\mathrm{Kg}$ ) dos leitões conforme o tratamento, sexo e fase de criação

Tabela 5 - Conversão alimentar (g) dos leitões conforme o tratamento, sexo e fase de criação

Tabela 6 - Comportamentos observados durante a fase de maternidade e as respectivas médias das frequências relativas (\%) e erro padrão, dentro dos dois tratamentos: controle e aversivo

Tabela 7 - Valores de P para as interações entre tratamento e dia, tratamento e minuto, para os comportamentos ativo, inativo, defecando e atenção para o objeto

Tabela 8 - Etograma de Trabalho: comportamentos observados durante o último dia antes do jejum pré-abate em suínos de terminação e suas definições ..

Tabela 9 - Frequência (média \pm erro padrão\%) dos comportamentos "no comedouro" e "repouso" observados durante o último dia de terminação (pré-abate) nos tratamentos controle, misto e aversivo

Tabela 10 - Frequência (média \pm erro padrão \%) dos comportamentos "interação agonística", fuçando/explorando", "na lâmina d'água", observados durante o último dia de terminação (pré-abate), nos tratamentos controle, misto e aversivo, e com enriquecimento ou sem enriquecimento 
Tabela 11 - Ganho de peso $(\mathrm{Kg})$, conversão alimentar $(\mathrm{g})$ no crescimento e terminação e peso $(\mathrm{kg})$ no início da terminação e no pré-abate de animais que receberam tratamento controle, misto ou aversivo, com ou sem enriquecimento

Tabela 12 - Concentração de cortisol $\left(\mu \mathrm{g} \cdot \mathrm{dL}^{-1}\right)$ e CPK $\left(U \cdot \mathrm{L}^{-1}\right)$ para suínos que receberam tratamento controle, misto, aversivo, com enriquecimento (CE) e sem enriquecimento (SE).

Tabela 13 - Média e erro padrão das variáveis analisadas para aferir qualidade de carne e de carcaça para animais que receberam tratamento controle, mista ou aversiva, com enriquecimento (CE) ou sem enriquecimento (SE)..

Tabela 14 - Classificação da carne suína (WARNER; KAUFFMAN; GREASER, 1997) de acordo com o tratamento recebido: controle, misto, aversivo, com enriquecimento (CE) ou sem enriquecimento (SE), com máximos e mínimos valores encontrados dentro de cada tratamento 


\section{LISTA DE ABREVIATURAS E SÍMBOLOS}

\begin{tabular}{|c|c|}
\hline${ }^{\circ} \mathrm{C}$ & Graus Célsius \\
\hline$\mu g . d l^{-1}$ & Microgramas por decilitros \\
\hline A & Ampere \\
\hline a* & Croma que varia de verde ao vermelho \\
\hline ACTH & Adrenocorticotropina \\
\hline ATP & Adenosina trifosfato \\
\hline $\mathbf{b}^{*}$ & Croma que varia do azul ao amarelo \\
\hline $\mathrm{cm}$ & Centímetro \\
\hline $\mathrm{cm}^{2}$ & Centímetros quadrados \\
\hline CRH & Hormônio corticotrófico \\
\hline DFD & Dark, firm, dry (escura, firme e seca) \\
\hline EM & Energia Metabolizável \\
\hline EGS & Espessura de gordura subcutânea \\
\hline G & Grama \\
\hline GPD & Ganho de Peso Diário \\
\hline HHA & Eixo Hipotálamo-Hipófise-Adrenal \\
\hline Kcal.g & Quilocaloria por grama \\
\hline Kg & Quilograma \\
\hline $\mathrm{Km}$ & Quilômetro \\
\hline $\mathbf{L}^{*}$ & Croma associada à luminosidade \\
\hline Máx. & Máximo \\
\hline Min. & Mínimo \\
\hline m & Metro \\
\hline ml & Mililitro \\
\hline $\mathrm{mm}$ & Milímetro \\
\hline$\mu \mathrm{Mol} . \mathrm{L}^{-1}$ & Milimol por litro \\
\hline PB & Proteína Bruta \\
\hline PCF & Peso da carcaça fria \\
\hline PCQ & Peso de carcaça quente \\
\hline PGF2a & Prostaglandina F2 alfa \\
\hline PSE & Pale, soft, exudative (pálida, molde e exudativa) \\
\hline PVC & Policloreto de vinila \\
\hline (B) & Marca registrada \\
\hline $\mathbf{v}$ & Voltagem \\
\hline U. $\mathrm{L}^{-1}$ & Unidades por litro \\
\hline
\end{tabular}




\section{SUMÁRIO}

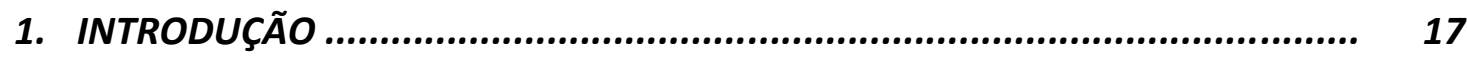

2. REVISÃO BIBLIOGRÁFICA................................................................... 19

2.1. RELAÇÃO ENTRE HUMANOS E ANIMAIS DE PRODUÇÃO: histórico, tipos de interações e consequências ............................................................... 19

2.2. A CRIAÇÃO DO CONCEITO DE BEM-ESTAR ANIMAL ........................... 22

2.2.1. Componentes fisiológicos indicadores de bem-estar animal: mensuração de hormônios indicativos de estresse e desgaste muscular

2.2.2. Componentes emocionais indicadores de bem-estar animal: reconhecimento de coespecíficos e humanos e testes para aferir medo em suínos

2.2.3. Componentes comportamentais indicadores de bem-estar animal: comportamento natural de suínos versus a vida no confinamento ....... 28

2.2.3.1. O papel do enriquecimento ambiental para suínos

2.2.4. Componentes produtivos indicadores de bem-estar animal: qualidade de carne em suínos

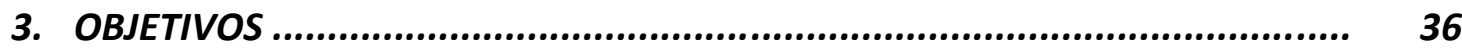

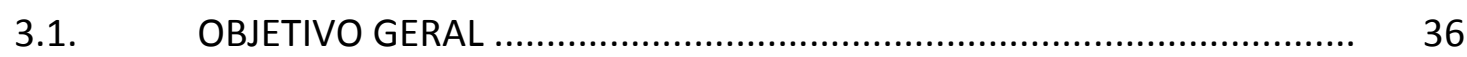

3.2. OBJETIVOS ESPECÍFICOS …......................................................... 36

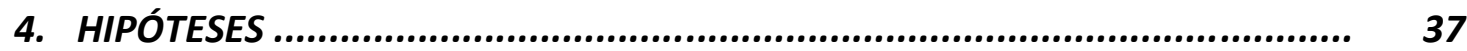

5. METODOLOGIA GERAL............................................................... 38

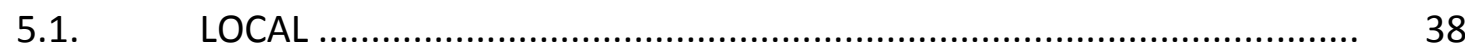

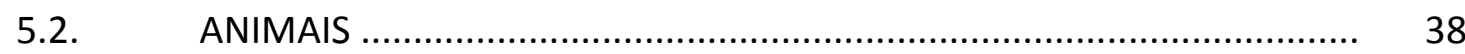

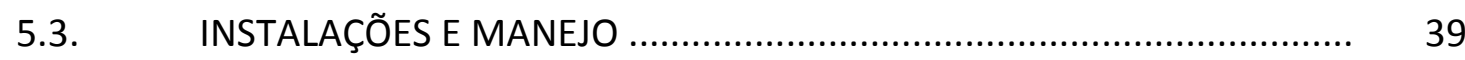

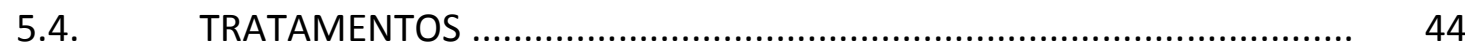

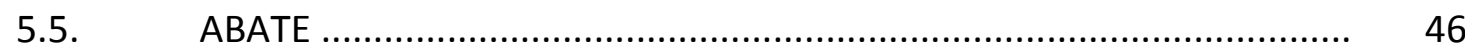

5.6. ANÁLISE ESTATÍSTICA DOS DADOS ................................................. 46

5.7. CONSELHO DE ÉTICA …............................................................... 47

6. EFEITO DA QUALIDADE DO TRATAMENTO, DO NASCIMENTO AO ABATE, SOBRE O DESEMPENHO E COMPORTAMENTO DE SUÍNOS ......................... 48

6.1. METODOLOGIA ............................................................................... 50

6.1.1. Desempenho ............................................................................... 50

6.1.2. Observação do comportamento dos animais ...................................... 50

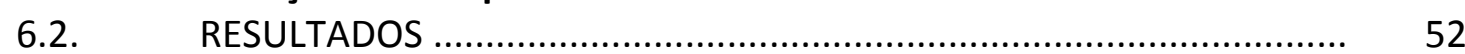

6.2.1. Desempenho ............................................................................... 52

6.2.2. Observação dos comportamentos dos animais .................................. $\quad 54$

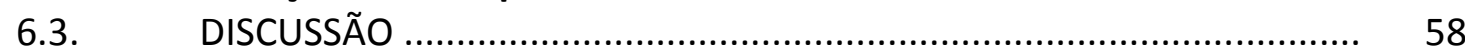

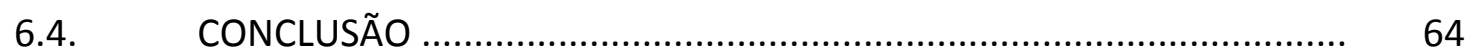

7. EFEITO DA QUALIDADE DO TRATAMENTO NO MEDO DE SUÍNOS ............. 65

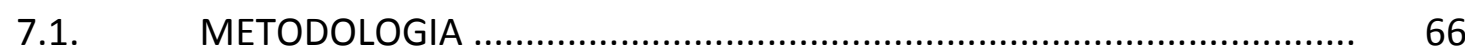


7.1.1. Teste de Aproximação Humana ......................................................... 66

7.1.2. Testes de medo em suínos ................................................................ 67

7.1.2.1. Teste de Área Desconhecida .............................................................. 68

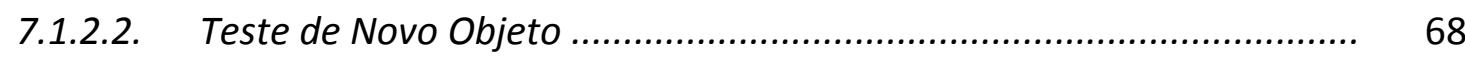

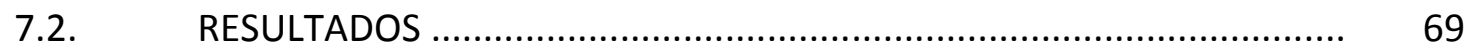

7.2.1. Teste de Aproximação Humana ......................................................... 69

7.2.2. Testes de medo em suínos ................................................................. $\quad 70$

7.2.2.1. Teste de Área Desconhecida ........................................................... $\quad 70$

7.2.2.2. Teste de Novo Objeto .................................................................... 71

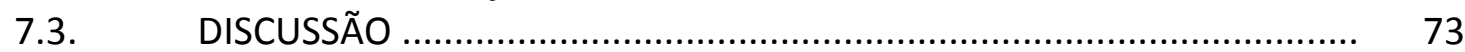

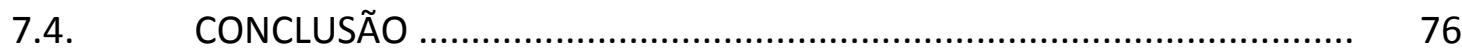

8. EFEITO DO ENRIQUECIMENTO AMBIENTAL NO COMPORTAMENTO E DESEMPENHO DE SUÍNOS TERMINADOS DE ACORDO COM A QUALIDADE DO TRATAMENTO RECEBIDO .............................................................. 77

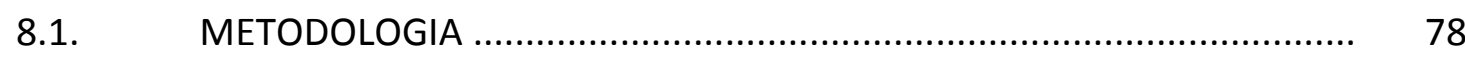

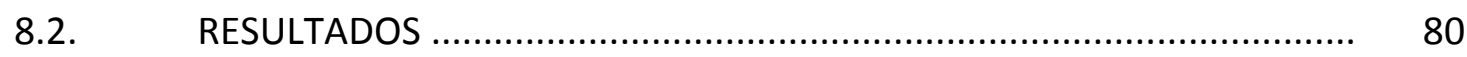

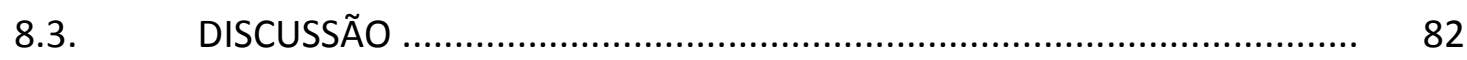

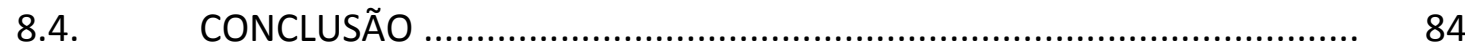

9. EFEITO DA QUALIDADE DO TRATAMENTO SOBRE A QUALIDADE DA CARNE DE SUÍNOS ..................................................................................... 85

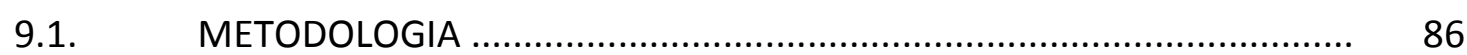

9.1.1. Avaliação quantitativa da carcaça ................................................... 88

9.1.1.1. Peso e rendimento de carcaça .......................................................... 88

9.1.1.2. Área de olho de lombo e espessura de toucinho ................................ 88

9.1.2. Avaliação qualitativa da carcaça ........................................................ $\quad 89$

9.1.2.1. pH e temperatura de carcaça ....................................................... 89

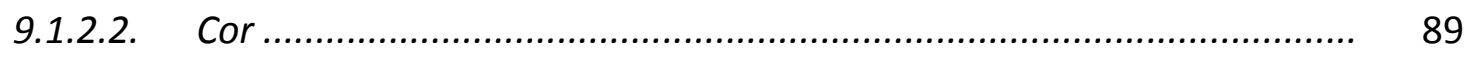

9.1.2.3. Drip loss ou perda de água por gotejamento................................... 90

9.1.2.4. Perda de água por cocção e maciez................................................... 90

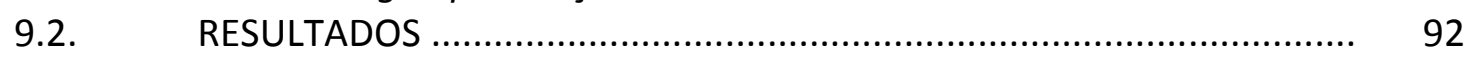

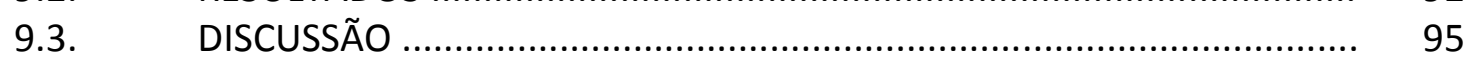

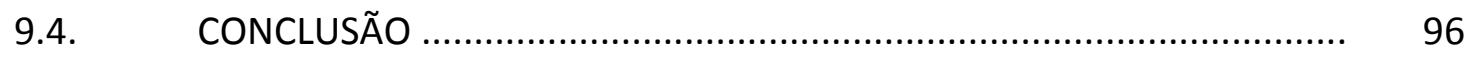

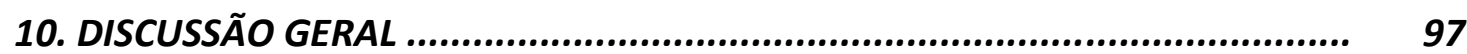

11. CONCLUSÃO GERAL .............................................................. 100

12. CONSIDERAÇÕES FINAIS ............................................................ 101

REFERÊNCIAS BIBLIOGRÁFICAS .......................................................... 102 


\section{INTRODUÇÃO}

A presente tese de doutorado trata da relação entre o tipo de tratamento recebido pelos leitões e a influência deste fator no comportamento, medo, desempenho e qualidade de carne. Várias questões sobre este tema foram levantadas para orientar este trabalho. A primeira questão era se animais tratados de forma aversiva apenas no início da vida teriam dificuldade para enfrentar novos manejos estressantes comuns à produção de suínos (p. ex. mudança de ambiente, pesagem, transporte). Outra questão era se suínos tratados de forma aversiva durante toda sua vida teriam maior dificuldade de enfrentar os mesmos manejos estressantes. Para responder ambas as perguntas, os grupos de animais deveriam ser comparados com um grupo que recebesse um tratamento neutro como controle. Somado a isso, será que estes animais reconheceriam o tratador habitual? Será que os animais tratados de forma aversiva demonstrariam mais medo? Qual a influência disso na qualidade da carne?

A produção nacional de suínos é composta basicamente de integração, onde a agricultura familiar trabalha juntamente com grandes empresas ou cooperativas. Neste caso, as granjas são manejadas por poucas pessoas que têm contato constante com os leitões e as porcas. Este contato direto e diário entre animal e tratador pode influenciar diretamente o padrão comportamental do suíno e, consequentemente, influenciar na dinâmica de manejo da granja. Trabalhar para que a interação entre tratadores e animais seja positiva traz benefícios para produtividade, facilidade de manejo e melhoria no bem-estar dos animais e dos trabalhadores envolvidos.

Suínos criados em confinamento convencional se deparam com várias situações potencialmente estressantes como corte ou desgaste de dentes, castração cruenta e sem anestesia, desmame precoce e abrupto, mistura de leitegada para formação de lotes homogêneos, superlotação, transferência de sala, manejo de vacinação, jejum pré-abate, transporte, espera pré-abate e abate. A presença de um tratador aversivo pode piorar a resposta dos leitões a estas situações, agravando ainda mais o estresse sofrido pelos animais. Animais estressados tendem a demonstrar maior probabilidade a doenças, 
problemas reprodutivos, baixo ganho de peso, baixa qualidade de carne e comportamentos anormais, colocando em risco o bem-estar do animal.

Este trabalho trata da relação entre humanos e suínos como principal agravante do distresse sofrido pelos animais. Para minimizar os efeitos negativos do confinamento no desempenho e no bem-estar animal, é importante entender como o medo que os suínos podem sentir de humanos está relacionado com o manejo, influenciando o comportamento, o estresse e o bem-estar dos leitões. Como a prática do confinamento é comum aos criadores de suínos, mudanças no modo de tratar os animais podem provocar grandes melhoras para o bem-estar dos mesmos. 


\section{REVISÃO BIBLIOGRÁFICA}

2.1. RELAÇÃO ENTRE HUMANOS E ANIMAIS DE PRODUÇÃO: histórico, tipos de interações e consequências.

Há mais de 12 mil anos, na era do gelo, os humanos eram nômades ou seminômades e viviam em pequenos grupos que obtinham seus recursos alimentares através da caça e da coleta. Assim que esses recursos acabavam na região onde estavam, eles se mudavam para outra área com mais alimentos. Ao fim da era do gelo, os humanos iniciaram um processo de sedentarização, onde era possível acumular recursos com a finalidade de não se mudar com constância. A domesticação de animais e de plantas foi crucial para esse feito. O primeiro animal a ser domesticado foi o lobo, seguido da ovelha e da cabra. Há 9 mil anos, porcos e vacas foram domesticadas, seguidos pelos cavalos, camelos, búfalos e aves (SERPELL, 1996).

Esta mudança de caçador para criador de animais mudou a relação entre humanos e animais. Se, antes, homens e animais eram livres e tinham a mesma chance de sobrevivência, com a domesticação os animais se tornaram totalmente dependentes dos cuidados dos humanos (SORABJI, 1995). A própria definição de domesticação retrata essa ligação entre humanos e animais:

A domesticação é o processo pelo qual uma população de animais se torna adaptado para o homem e para o ambiente em cativeiro através de combinações de mudanças genéticas que ocorrem ao longo de gerações e pelas mudanças induzidas pelo ambiente durante cada geração (PRICE, 1984).

Na Grécia antiga, começou a discussão sobre animais possuírem alma e razão e, com a negação disso, os animais foram subjugados e sua existência foi ligada à servidão aos humanos (SORABJI, 1995). Essa rejeição do animal como "ser" foi declarada por Descartes com sua publicação do "Discurso do Método" no século XVII (DESCARTES, 1989). Neste livro, Descartes assumia os animais como máquinas, negando que eles tenham razão, emoção e dor. Algumas pessoas se opuseram a ideia cartesiana (VOLTAIRE, 1989; BENTHAM, 1989), mas a visão dos animais como máquinas se manteve por muitos anos. 
A produção agropecuária foi quadruplicada entre os anos de 1820 e 1975 para alimentar a população que também quadriplicou: subiu de um bilhão de pessoas em 1800 para quatro bilhões em 1975 (SCULLY, 2002). A criação animal, antes feita para subsistência da família, deu lugar à produção animal, onde menos pessoas eram responsáveis por mais animais que dariam produtos às pessoas que viviam fora do campo. Antes da Segunda Guerra mundial, $24 \%$ da população da América do Norte, por exemplo, trabalhava na agricultura; no início dos anos 2000 , apenas $1,5 \%$ desta população tinha o mesmo papel (SCULLY, 2002). Com a diminuição das pessoas no campo e a diminuição do número de pessoas necessárias para cuidar de uma grande produção, houve um afastamento entre os humanos e os animais de produção (ROLLIN, 1995).

Apesar deste afastamento geral entre humanos e animais, somado ao reduzido número de pessoas trabalhando no campo e o aumento da tecnologia para ajudar nas tarefas diárias, o trabalhador do campo manteve uma relação estreita com os animais que maneja diariamente (HEMSWORTH; COLEMAN, 2011). Devido a essa ligação, tanto o comportamento do humano pode influenciar a vida do animal, como vice-versa (BOKKERS, 2006).

As interações entre homens e animais podem ser físicas ou não físicas, de natureza positiva, neutra ou negativa. Interações físicas são aquelas onde há contato direto entre o animal e o humano (p. ex. bater ou acariciar). Interações não físicas são aquelas que não permitem contato físico direto, como posicionamento corporal e tom de voz do humano em relação ao animal (HEMSWORTH; COLEMAN, 2011). Interações positivas são as que trazem algum benefício ou recompensa ( $p$. ex. alimentação). Interações neutras são as que não trazem malefícios ou benefícios diretos. Em longo prazo, interações neutras acabam por ser positivas já que têm reduzidas chances de causar medo aos animais. Interações negativas são aquelas que trazem algum mal aos envolvidos e estão presentes na rotina da produção animal como a castração cruenta e sem anestesia, injeções, condução forçada de animais e jejum (LENSINK, 2002).

Quando as práticas negativas aos animais são frequentes, elas podem aumentar o medo sentido pelos animais com relação aos humanos (HEMSWORTH, 2003). Dessa forma, os animais podem ver o humano como uma possível ameaça e reagir negativamente a sua 
presença, dificultando o manejo ou trazendo riscos ao tratador. O humano, por sua vez, vai tratar este animal de forma ainda mais negativa em retaliação a dificuldade de manejo, e isto vai gerar um processo de retroalimentação indesejável caracterizado pela insatisfação do tratador e prejuízos para o bem-estar de ambos: tratador e animal (HEMSWORTH, 1993). Este ciclo, conhecido como "Modelo de Relação Humano-Animal" foi proposto por Hemsworth e Coleman (1998) e explica a influência da interação humano-animal na produtividade e bem-estar animal. Neste modelo (Figura 1), considera-se que as atitudes do tratador vão direcionar seu comportamento que, por sua vez, pode influenciar a resposta de medo no animal. O medo do animal vai estar intimamente ligado ao bem-estar e produtividade animal, mas também vai retroalimentar as atitudes e comportamento do tratador, fechando o ciclo.

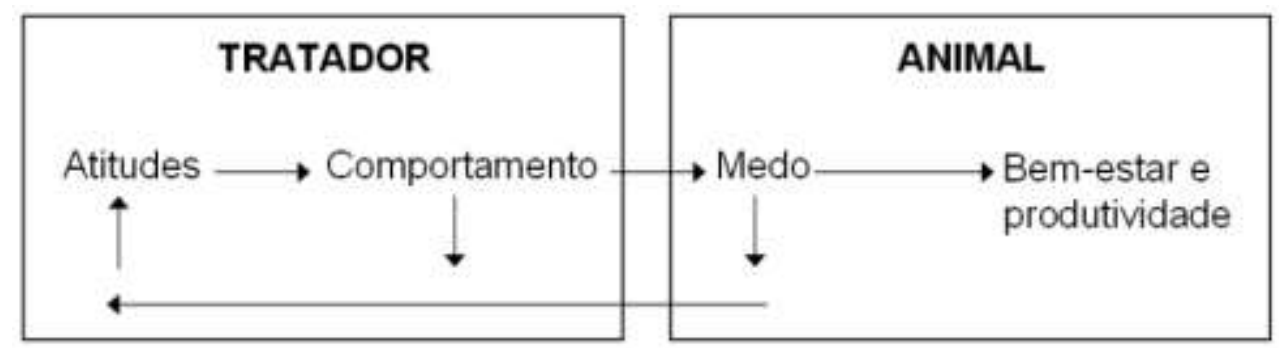

Figura 1: Modelo de relação humano-animal proposto por Hemsworth e Coleman em 1998.

Vários trabalhos correlacionaram a interação negativa entre tratador e animal com o medo do animal e problemas de produtividade: suínos (HEMSWORTH; BARNETT; HANSEN, 1981, 1986, 1987; GONYOU; HEMSWORTH; BARNET, 1986; HEMSWORTH; BARNETT, 1991); frango de corte (CRANSBERG; HEMSWORTH; COLEMAN, 2000); poedeiras (BARNETT; HEMSWORTH; NEWMAN, 1992); gado leiteiro (HEMSWORTH et al., 2000). No caso de suínos, o tempo despendido em segundos para interagir com o humano foi mais elevado em animais tratados de forma negativa do que os tratados de forma positiva. Os mesmos animais tratados de forma negativa tiveram menor taxa de crescimento, maior concentração de cortisol plasmático, menor taxa de prenhes e maior peso de glândula adrenal em comparação com animais que receberam tratamento positivo ou neutro (HEMSWORTH; BARNETT; HANSEN, 1981, 1986, 1987; HEMSWORTH; COLEMAN; COX, 1994; HEMSWORTH; 
BARNETT; CAMPBELL, 1996; GONYOU; HEMSWORTH; BARNET, 1986; HEMSWORTH; BARNETT, 1991; HEMSWORTH; COLEMAN; COX, 1994). Uma relação negativa entre tratador e animal também pode trazer problemas comportamentais para os animais, como aumento de comportamentos indicativos de estresse - interações agonísticas e tentativa de fuga (SOMMAVILLA; HÖTZEL; DALLA COSTA, 2011).

Por outro lado, interação positiva entre animais e humanos em um ambiente desfavorável pode amenizar o estresse crônico sofrido pelos animais (PEDERSEN et al., 1998), melhorando sua qualidade de vida. Assim como os tratadores de animais foram treinados para realizar observações técnicas e especificas como detecção de cio, colheita de sêmen, inseminação artificial e até mesmo tratar doenças, estes profissionais podem e devem ser treinados para observar o comportamento dos animais e melhorar sua relação com eles. Melhorar o fator "humano" na relação humano-animal pode ser a chave para melhoria do bem-estar animal dentro da produção (HEMSWORTH; COLEMAN, 1998).

\subsection{A CRIAÇÃO DO CONCEITO DE BEM-ESTAR ANIMAL}

Em 1964, Ruth Harrison publicou o livro intitulado "Animal Machines", onde retratava a produção animal na Grã-Bretanha e denunciava abusos e maus tratos com os animais criados. Este livro acabou retomando as discussões sobre ética e os direitos dos animais sentenciadas na Grécia Antiga e aceitas, até então, como verdade. No ano seguinte, o Parlamento criou o Comitê Brambell com a finalidade de investigar as acusações contidas no livro de Harrison. Visto a veracidade dos fatos, o Comitê propôs cinco liberdades mínimas que todos os animais deveriam ter: virar-se, cuidar de seu próprio corpo, levantar-se, deitarse e esticar seus membros. Em 1968, foi criada a "Farm Animal Welfare Advisory Council", que em 1973 mudou seu nome para "Farm Animal Welfare Council" (e mantém esse nome até os dias de hoje), onde, em 1979, instituiu cinco liberdades que animais de produção deveriam ter: livres de fome e sede; livres de desconforto; livres de dor, injúria e doença; livres de medo e estresse; livres para expressar seus comportamentos naturais.

"Bem-estar animal" foi um conceito construído por vários pesquisadores. Dawkins (1988) dizia que para pensar em bem-estar animal, antes deveria pensar nos sentimentos 
subjetivos dos animais, principalmente os sentimentos negativos como sofrimento e dor. Em 1985, Moberg trouxe o estresse à discussão e concluiu que o estresse é parte da vida e, sozinho, não pode indicar o grau de bem-estar do animal. O estresse só é maléfico ao animal quando resulta em mudanças biológicas, a ponto de expor ele a doenças. Broom (1991) acredita que o bem-estar não é algo que pode ser dado pelo humano: é inerente ao animal, referindo-se às tentativas que o ser tem de se adaptar ao meio (quanto maior o esforço empregado para que o indivíduo consiga se adaptar ao meio, mais pobre será o seu bemestar). O autor também frisa que a ausência de sofrimento por si só não é sinônimo de bemestar animal, existindo mais itens a serem avaliados. Para Duncan (1993), o bem-estar não se resumia apenas em boa saúde e ausência de distresse, apesar de serem extremamente necessários ao animal. Para o pesquisador, bem-estar animal está ligado ao que o animal sente. Esta ideia é reforçada por McGlone (1993) que sugeriu que o animal estaria em pobre bem-estar se houvesse um distúrbio de seu sistema fisiológico a ponto de por em risco a sobrevivência e/ou reprodução do animal. No mesmo ano (1993), Hurnik caracterizou o bem-estar animal como longevidade somada a ótimas condições físicas e fisiológicas. Para Barnard e Hurst (1996) altas taxas reprodutivas de forma eficiente ao animal (sem desgaste desnecessário) seriam uma boa forma de mensurar bem-estar animal. Já em 2004, Waiblinger e colaboradores concluíram que os comportamentos naturais devem ser levados em consideração e que os animais devem estar aptos para realizá-los, além de evitar o sofrimento e promover uma alta qualidade de vida a estes indivíduos.

Agrupando todos estes conceitos, pode-se dizer que para ter acesso ao grau de bemestar do animal, deve-se ter acesso a componentes fisiológicos (p. ex. hormônios), comportamentais, emocionais, cognitivos e produtivos. O uso de apenas um desses componentes para averiguar o bem-estar do animal pode trazer uma resposta equivocada (FRASER, 2008).

\subsubsection{Componentes fisiológicos indicadores de bem-estar animal: mensuração de hormônios indicativos de estresse e desgaste muscular}

A mensuração dos hormônios indicativos de estresse foi proposta como um indicativo de bem-estar animal, apesar de que o estresse sozinho não poderia ser 
responsável pelo pobre bem-estar do animal (MOBERG, 1985), devendo ser levado em consideração às mudanças do padrão comportamental apresentado pelo animal concomitantemente com as aferições bioquímicas. Por definição, estresse é a reação biologia a estímulos adversos, sejam eles emocionais, físicos ou mentais, de natureza interna ou externa, e que tenha a capacidade de perturbar a homeostase do organismo (BLOOD; STUDDERT, 2002). O estresse pode ser dividido em "eustresse" e "distresse". O "eustresse" é um estímulo benigno ao animal, apesar de causar mudanças hormonais (p. ex. eustresse pré-cópula). O “distresse" pode ser crônico e prejudicial ao animal, podendo ter consequências patológicas e de pobre bem-estar animal (p. ex. presença de um predador. MORTON, 1998).

Para explicar a resposta orgânica ao estresse, Hans Selye (1952) escreveu o livro "The Story of the Adaptation Syndrome", com detalhamento da Síndrome Geral da Adaptação proposta por ele em 1946. Esta Síndrome foi dividida em três partes, sendo que cada parte corresponde à resposta orgânica ao estresse de forma cumulativa e sequencial: 1) fase de alarme, onde o organismo se arma prontamente para lutar ou fugir do estressor, sendo assim, uma fase de grande gasto energético para o animal; 2) fase de resistência, em que o organismo tenta recuperar os danos causados pela fase de alarme; 3) fase de exaustão, associada ao estresse crônico, esta fase traz problemas de imunidade, deficiência metabólica e reprodutiva, doenças e alteração do funcionamento hormonal.

Na figura 2 tem-se um esquema da resposta neuroendócrina do estresse no organismo animal (adaptada de MATTERI; CARROLL; DYER, 2000). No momento que os neurotransmissores receberam estímulos internos e externos ao organismo, eles transmitem esta informação ao Sistema Nervoso Autônomo (SNA) e ao eixo hipotálamohipófise-adrenal (HHA). O SNA é responsável pelas respostas fisiológicas rápidas e age prontamente na medula da Glândula Adrenal, aumentando a produção das catecolaminas (adrenalina e noradrenalina). As catecolaminas têm a função de aumentar a frequência respiratória e a dilatação dos brônquios para aumentar a oxigenação; aumentar a frequência cardíaca para aumentar o aporte sanguíneo; atuar na redistribuição sanguínea das vísceras e pele para os músculos e cérebro; atuar no fígado para que haja liberação da glicose armazenada para aumentar a energia dos músculos; dilatar as pupilas para aumentar a visão. Esta resposta é rápida e de curta duração. 
O HHA age no córtex da Glândula Adrenal, induzindo a produção de glicocorticoides. Uma das funções dos glicocorticoides no organismo é estimular a transformação de nãoaçúcares em glicose, aumentando a energia disponível. Para isso, uma das fontes utilizada é o glicogênio muscular, resultando num aumento dos níveis de lactato plasmáticos. O uso excessivo das reservas musculares de glicogênio pode culminar em sua exaustão. Uma enzima denominada como creatina-fosfoquinase pode ser usada para medir essa exaustão muscular (SHAW; TUME, 1992). Sendo assim, o lactato e a creatina-fosfoquinase, juntamente com cortisol e seus metabolitos, podem ser usados como ferramentas fisiológicas para aferir estresse e desgaste muscular em animais. O parâmetro bioquímico de um suíno Large White sob o mínimo de estresse é de $6,35 \mu \mathrm{Mol} . \mathrm{g}^{-1}$ de lactato (LEBERT et al., 2006), 965 U/L de CPK (WARRISS et al., 1994) e 4,8 $\mu \mathrm{g} \cdot \mathrm{dL}^{-1}$ de cortisol (FAGUNDES et al., 2008).

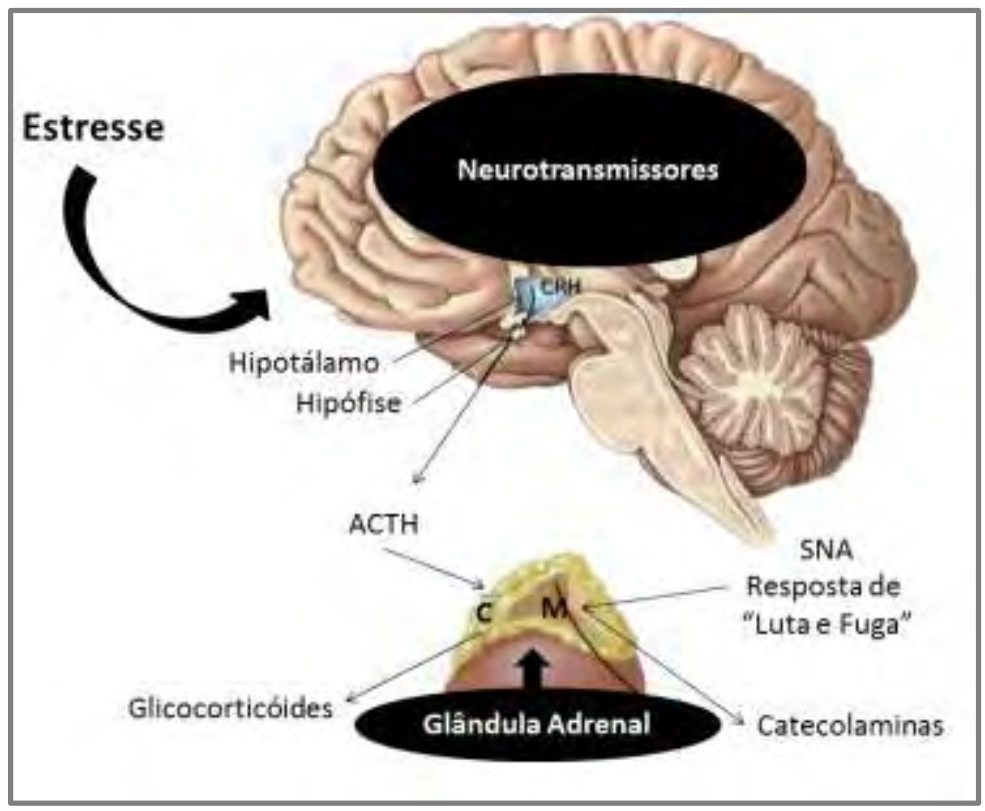

Figura 2: Diagrama da resposta neuroendócrina ao estresse (adaptado de MATTERI; CARROLL; DYER 2000). SNA: Sistema Nervoso Autônomo. C: Córtex da Glândula Adrenal. M: Medula da Glândula Adrenal. ACTH: Hormônio Adrenocorticotrófico. CRH: Hormônio liberador de corticotrofina. 


\subsubsection{Componentes emocionais indicadores de bem-estar animal: reconhecimento de coespecíficos e humanos e testes para aferir medo em suínos}

Suínos têm alta motivação em explorar e, para isso, possuem o olfato e a audição bem desenvolvidos, em contraste com a pobre visão (SPOOLDER; WAIBLINGER, 2009). Eles usam desses atributos para reconhecer e distinguir coespecíficos e humanos. Suínos podem reconhecer animais familiares. Esta conclusão se dá pelo fato de que se animais desconhecidos forem misturados, eles vão brigar, mas isso não acontece se misturar animais conhecidos (MENDL et al., 2001). A capacidade cognitiva e o desenvolvimento cerebral do suíno (e de outras espécies) sofrem influência direta do ambiente que o cerca, desde os primeiros dias de vida (HELD; COOPER; MENDL, 2009). Estresse nas primeiras semanas de vida como isolamento social, pode influenciar negativamente a habilidade de reconhecimento social de suínos (SOUZA; ZANELLA, 2008). Estes animais podem ter problemas de aprendizado e memória e, assim, terem pobre bem-estar e dificultarem o manejo na granja (MENDL, 1999).

O animal pode perceber o humano de cinco formas diferentes: o humano como um predador; o humano como uma presa; o humano como parte do ambiente, sem nenhum significado social; o humano como o outro lado da simbiose; o humano como um coespecífico (HEDIGER, 1965 apud SPOOLDER; WAIBLINGER, 2009).

Os animais podem generalizar ou distinguir humanos diferentes. A generalização ocorre quando o animal responde a todos os humanos da mesma forma, sem distinção (THORNDIKE, 1913). Alguns estudos sugerem que suínos são incapazes de discriminar pessoas diferentes (HEMSWORTH; BARNETT; HANSEN, 1981; HEMSWORTH; COLEMAN; COX, 1994; HEMSWORTH; BARNETT; CAMPBELL, 1996). Neste caso, se eles tiverem contato com uma pessoa aversiva, podem evitar todas as pessoas que se aproximem deles, trazendo problemas de manejo, bem-estar e produtividade (HEMSWORTH; BARNETT; HANSEN, 1981; HEMSWORTH; VERGE; COLEMAN, 1996; HELD; COOPER; MENDL, 2009). Por outro lado, há autores que afirmam que os animais usam de suas habilidades sensoriais para distinguir humanos (TANIDA; NAGANO, 1998; KOBA; TANIDA, 1999; SOMMAVILLA; HÖTZEL; DALLA COSTA, 2011). Koba e Tanida (2001) afirmam que o tamanho da pessoa e sua postura estão mais associados ao reconhecimento do que a sua própria face, mas ainda não se sabe quais 
as pistas que os animais usam para distinguir pessoas, sendo esta distinção altamente relacionada com a intensidade da interação entre humanos e animais (HELD; COOPER; MENDL, 2009).

O medo é um estado emocional em resposta a percepção do perigo (BOISSY, 1995), manifestando-se nos animais através de luta ou fuga (BLOOD; STUDDERT, 2002). Este estado está ligado a estímulos que podem trazer risco ao bem-estar do animal, ocasionando uma série de respostas físicas e psicológicas (HEMSWORTH; COLEMAN, 1998). A resposta fisiológica do medo é semelhante à resposta fisiológica do estresse (distresse) explicada anteriormente. Quando o animal sentir medo de alguém ou de um objeto, vai evitar a convivência. Quanto maior for o ato de evitar realizado pelo animal, menor será seu bemestar (BROOM; FRASER, 2007).

Existem alguns testes comportamentais validados para acessar o medo em suínos. Os mais conhecidos são os Testes de Área Desconhecida (open field), Novo Objeto e Aproximação Humana. Forkman e colaboradores (2007) sugerem o uso destes testes de forma combinada, para evitar conclusões errôneas, apesar de a correlação entre os testes não ser muito elevada (MURPHY; NORDQUIST; VAN DER STAAY, 2014). Os testes realizados devem levar em consideração alguns tópicos sugeridos por Gieling e colegas (2011) e revisado por Murphy e coautores (2014):

1) Os testes devem ser saudáveis ao animal que deve estar apto a respondê-lo, levando em conta a singularidade da espécie (ser ecologicamente válidos);

2) Devem promover a análise detalhada do comportamento a ser estudado, devendo ser sensível ao que se quer acessar;

3) O teste deve ser capaz de ver diferenças através do tempo e ser repetido com facilidade;

4) Os animais devem estar habituados aos procedimentos realizados antes de serem testados para evitar que o estresse na novidade influencie a resposta do animal (a não ser que a novidade faça parte do teste);

5) O teste realizado deve estar validado;

6) Sempre que possível, o teste deve ser automatizado para evitar a influência da presença do manejador ou do observador na resposta do animal; 
O Teste de Área Desconhecida é comumente utilizado em suínos e tem a finalidade de ver a resposta do animal a um ambiente desconhecido (FRASER, 1974) e ao fator de isolamento social (MURPHY; NORDQUIST; VAN DER STAAY, 2014). Para tal, são observados comportamentos como: deitado, em pé, explorando, defecando, urinando e vocalizações. O tamanho da área pode variar com a disponibilidade do local e o tempo que o animal é deixado dentro da área desconhecida é de, no mínimo, 5 min (FORKMAN et al., 2007). Normalmente, este teste é realizado com um animal por vez, sendo o isolamento social uma importante ferramenta para o acesso do medo (PRUT; BELZUNG, 2003).

O teste de Novo Objeto pode ser realizado depois do Teste de Área Desconhecida, visto que, desta forma, o animal estará habituado ao ambiente (FORKMAN et al., 2007). Este teste tem como finalidade acessar o medo e a ansiedade perante a algo não familiar aos animais - novidade. $\mathrm{O}$ objeto a ser testado pode estar presente na área de teste antes do animal chegar ou pode ser colocado, de forma sutil ou abrupta, no local, quando o animal estiver presente (MURPHY; NORDQUIST; VAN DER STAAY, 2014). Então, são observadas a latência, frequência e duração de contato com este novo objeto (FORKMAN et al., 2007).

O teste de interação humano-animal pode ser realizado de duas formas: ou o humano fica parado esperando o animal encostar-se a ele e, neste caso, a latência até o contato é aferida; ou o humano vai de encontro do animal, de forma suave e a resposta do animal a esta aproximação é aferida (MARCHANT-FORDE, 2002). A primeira forma de teste é mais recomendada para ver a motivação do animal em interagir com o humano. A segunda forma está mais ligada ao medo, visto que é uma resposta de evitação do animal (MURPHY; NORDQUIST; VAN DER STAAY, 2014).

\subsubsection{Componentes comportamentais indicadores de bem-estar animal: comportamento natural de suínos versus a vida no confinamento}

Para acessar o padrão comportamental, deve-se conhecer o comportamento desta espécie em vida natural e o comportamento em cativeiro: mudanças, adaptações, estereotipias e entraves. 
Leitões paridos em ambiente natural nascem em um ninho feito pela porca, onde estão protegidos do frio e de predadores. A mãe permanece no ninho com os filhotes na primeira semana de vida, saindo apenas para se alimentar, numa distância de até 15 metros (STANGEL; JASEN, 1991). Neste período, os leitões têm, além da proteção e companhia da mãe, toda a alimentação necessária para se desenvolver: o leite materno. Nas primeiras dez horas de vida, os leitões são amamentados a cada 40-80 minutos (FRASER, 1980) e a amamentação é estimulada pela porca que, frequentemente, vocaliza para chamar os leitões para mamar (BROOM; FRASER, 2007). A sucção do leite deve ser rápida, pois a sua ejeção dura cerca de 20 segundos (NEWBERRY; WOOD-GUSH, 1985). Durante o período de amamentação, a primeira hierarquia é formada de acordo com a ordem que os leitões estabelecem em relação aos tetos na hora de mamar (FRASER, 1980). Esta hierarquia é conhecida como "ordem da teta" e perdura durante toda a lactação (FRASER, 1975).

Após a primeira semana de vida, os leitões e sua mãe retornam ao convivo do grupo social antes frequentado pela porca (JENSEN; REBDO, 1991). Este grupo social é composto por, em média, quatro porcas e de seus filhotes da última leitegada, podendo ter alguns filhotes da penúltima leitegada ainda no grupo, dependendo do tamanho do local que habitam e das fontes de alimentação disponíveis (GRAVES, 1984). Desta forma, os leitões iniciam a socialização com os demais animais do grupo e começam a passar menos tempo como a porca (NEWBERRY; WOOD-GUSH, 1985). Vendo a porca se alimentar de sólidos, os leitões aprendem através da facilitação social, como fazê-lo também (GRAVES, 1984). Alimentando-se mais de sólidos e mamando cada vez com menor frequência, o desmame acontece de forma gradual e se completa quando os leitões têm, aproximadamente, quatro meses de vida (NEWBERRY; WOOD-GUSH, 1985). Com o desmame, a hierarquia da ordem da teta pode ser modificada e dar espaço para uma nova ordem hierárquica (GONYOU, 2001).

Quando atingem a maturidade, em torno do primeiro cio (de oito a dez meses de idade) as leitoas podem se manter no grupo da mãe ou formar novos grupos de fêmeas (GABOR et al., 1999). Já os machos saem do grupo da mãe quando completam aproximadamente $50 \mathrm{~kg}$ (de seis a dez meses de idade) e formam "grupos de solteiros" (TRUVÉ; LEMEL, 2003). Após essa segregação, machos e fêmeas só irão coabitar para copular (GRAVES, 1984). 
Animais confinados têm outra dinâmica de vida imposta pela indústria. Assim que nascem em um confinamento convencional, os leitões não têm um ninho para acomodá-los. Frequentemente, leitões de porcas diferentes são transferidos de mãe para igualar as leitegadas e otimizar o consumo de leite e crescimento da leitegada. Dependendo de quando essa transferência é feita, a ordem da teta pode ser desestabilizada ou a porca pode rejeitar o leitão enxertado que pode não conseguir mamar e morrer de inanição (JOHNSON e MARCHANT-FORDE, 2009). Outra prática comum é que os filhotes machos sejam castrados de forma cruenta e sem anestesia, já nos primeiros dias de vida. Alguns produtores cortam a cauda dos animais para evitar canibalismo. Esta prática pode ocasionar uma porta de entrada para infecções e causar abscessos que vão condenar a carcaça no abatedouro (GREGORY, 2007). Comumente, os dentes são cortados para evitar machucaduras no úbere da porca, sendo esta prática benéfica para a mãe e, desde que não exponha a polpa do dente, não traz prejuízos aos leitões (GREGORY, 2007). Durante a fase de maternidade, leitões e porcas têm um convívio exclusivo e alta frequência de amamentação (HÖTZEL et al., 2004), o que faz com que a produção de leite da porca seja inalterada e que os leitões não precisem de outra fonte de alimento que não seja o leite da mãe (PAJOR; FRASER; KRAMER, 1991).

Enquanto que na natureza o desmame ocorreria de forma gradual e terminaria em torno de quatro meses de idade do leitão, nos sistemas de criação convencional, os animais comumente são desmamados de forma abrupta e com duas a quatro semanas de idade (PAJOR; FRASER; KRAMER, 1991). Muitas vezes, com o desmame, os leitões são misturados a outras leitegadas com a finalidade de formar lotes homogêneos com relação a peso e sexo. Com a ruptura do grupo social (FRASER; BROOM, 1990) e a mistura com animais totalmente desconhecidos (AREY; FRANKLIN, 1995), os leitões tendem a brigar mais para estabelecer a nova hierarquia. Quanto mais homogêneo em relação a peso e sexo for o novo lote formado, maiores serão as interações agonísticas para a estabilização da hierarquia (ANDERSEN et al., 2000).

Além de enfrentarem as brigas para estabilizar a hierárquica, os animais desmamados precocemente precisam aprender a se alimentar de sólidos e se acostumar a não ter mais acesso a mãe e ao leite materno. A nova dieta constituída de grãos, óleo e açúcar, é abrasiva ao trato digestivo e pode causar diminuição das vilosidades do intestino 
delgado. Somado a isso, a baixa ingestão de alimento sólido nos primeiros dias pósdesmame, faz com que o pH do estômago se eleve, diminuindo a eficiência da digestão proteica e promovendo a proliferação de patógenos como Escherichia coli. A proliferação desta bactéria pode ocasionar o aparecimento de uma doença comum em leitões confinados, conhecida como "colibacilose da terceira semana", com quadros severos de diarreia, podendo culminar na morte do leitão infectado (SOBESTIANSKY, 1999).

Leitões com quatro semanas de idade têm forte motivação por mamar e a privação deste comportamento pode causar frustração e aparecimento de comportamentos anômalos. O mais conhecido é o "belly-nosing", frequente no pós-desmame abrupto e pouco visto em suínos em vida natural (MILLS, 2010). Este comportamento é caracterizado pelo movimento da cabeça para cima e para baixo, simulando uma massagem no úbere da mãe, onde o nariz do animal sugador é direcionado para a barriga ou flanco de outro leitão. É mais comum na fase de mudança de comportamento de ativo para descansando, podendo durar alguns minutos e trazer malefícios ao leitão sugado, como inflamações nos mamilos, umbigo, pênis ou escroto (BROOM; FRASER, 2007).

Somado a todas essas mudanças, os animais trocam o ambiente em que habitam. A sala de creche normalmente não tem escamoteador para que os animais possam se aquecer e eles não têm mais a presença da mãe para isso. Os comedores e bebedores podem ser diferentes do conhecido aos animais e eles podem ter dificuldade em se adaptar. Todas essas mudanças refletem no comportamento do leitão: animais desmamados precocemente respondem prontamente com um aumento das atividades comportamentais e aumento das vocalizações (WEARY; APPLEBY; FRASER, 1999).

Algumas alternativas para diminuir o impacto do confinamento no comportamento e bem-estar de suínos estão disponíveis aos produtores. As porcas podem ser criadas em baias individuais ou coletivas, ao invés de serem criadas em celas de gestação e celas parideiras (BROOM; FRASER, 2007). Elas podem receber substrato para montar o ninho no pré-parto. Os leitões podem ter contato com os leitões vizinhos antes do desmame para que possam se acostumar com os novos integrantes do grupo social pós-desmame: isso pode ser feito com a retirada das grades entre as baias durante a fase de maternidade (KANAAN et al., 2008). A ração pré-inicial pode ser oferecida durante a fase de maternidade para que os leitões 
comecem a se acostumar com alimentos sólidos mais precocemente (PAJOR; FRASER; KRAMER, 1991). Machos podem receber imunocastração no lugar de castração cruenta e sem anestesia. O desmame pode ser realizado de forma fracionada ou mais tardiamente (WEARY; JASPERS; HÖTZEL, 2008).

\subsubsection{O papel do enriquecimento ambiental para suínos}

Suínos confinados normalmente vivem em um ambiente simples, muitas vezes sem substrato no chão. Este ambiente pobre não permite que o animal exponha sua alta gama de comportamentos exploratórios (VON WEERD e Day, 2009). A privação da motivação por realizar estes comportamentos pode causar ao animal distresse e problemas psicológicos muitas vezes manifestados através de comportamentos anormais e estereotipias (WOODGUSH e BEILHARZ, 1983). Esta situação pode ser alterada ou, pelo menos, amenizada, com a inserção do enriquecimento ambiental, prática definida como:

A modificação de um confinamento estéril, com a finalidade de melhorar as
atividades biológicas dos animais, sendo este, extremamente especifica
para a espécie poder expressar seu mais complexo repertório
comportamental (Newberry, 1995).

Para animais com senso exploratório tão aguçado como os suínos, o enriquecimento ambiental ideal deve ser complexo, mutável, destruível, manipulável e conter partes comestíveis (STUDNITZ; JENSEN; PEDERSEN, 2006).

Quando confinados em ambientes estéreis (simples), os animais tentem a direcionar sua motivação de explorar ou fuçar a outros membros do grupo (BEATTIE et al., 2000). Esta interação pode se tornar agonística ou um comportamento anômalo como belly-nosing (BEATTIE; WALKER; SNEDDON, 1995). O enriquecimento ambiental reduz as interações agonísticas de porcas gestantes (AREY; SANCHA, 1996) e entre leitões (O'CONNELL e BATTIE, 1999), diminuindo a mortalidade de leitões causada pela porca (BEATTIE; WALKER; SNEDDON, 1995). Enriquecimento ambiental também pode diminuir comportamentos anômalos como belly-nosing (BENCH; GONYOU, 2006) e aumentar comportamentos lúdicos como brincadeiras (BEATTIE; WALKER; SNEDDON, 1995). 


\subsubsection{Componentes produtivos indicadores de bem-estar animal: qualidade de carne em suínos}

Após uma vida de confinamento, os animais são encaminhados ao abatedouro. O dia do abate contém uma série de situações potencialmente estressantes, como o agrupamento de animais desconhecidos para o transporte e espera do abate, o jejum pré-abate, o embarque, o desembarque, o transporte, o atordoamento e o abate (GADE, 2004).

O transporte de suínos deve ter o tempo necessário para o animal se recuperar do estresse sofrido no embarque e na provável mistura de grupo. Se o transporte durar 15 minutos, por exemplo, será pior para o bem-estar do animal do que um transporte de 3 horas. Pérez e colaboradores (2002) constataram que no transporte de 15 minutos, os animais demonstraram maior resposta ao estresse, com aumento da concentração de cortisol e lactato séricos e, consequentemente, menores valores de $\mathrm{pH}$. Por outro lado, viagens muito longas (acima de 16 horas) também podem afetar negativamente o bem-estar do animal (MOTA-ROJAS et al., 2006).

O tempo de espera no abatedouro que antecede o abate, também é importante para o bem-estar animal. Animais abatidos logo após o transporte (independente do tempo de transporte) tiveram maior perda de peso do que animais que descansaram 6 horas após o mesmo tempo de transporte (BROWN et al., 1999). Além disso, estes animais tiveram aumento da concentração de cortisol plasmático (WARRISS et al., 1998; PÉREZ et al., 2002), aumento da concentração de lactato e CPK e aumento das lesões de carcaça (WARRISS et al., 1998).

O atordoamento de suínos pode ser feito através de choque (eletricamente) ou por anestesia com dióxido de carbono. Na insensibilização elétrica, deve-se ter cuidado com a voltagem e posição dos eletrodos na cabeça do animal. Já a anestesia com dióxido de carbono deve levar em consideração a concentração do gás e o provável desconforto do animal antes de ser atordoado (LAWRIE, 2006).

Assim que o animal é sangrado, o aporte de oxigênio celular é cessado e o metabolismo celular continua de forma anaeróbica até o esgotamento das reservas de energia - ATP (LAWRIE, 2006). Com o fim do ATP, o músculo não consegue mais relaxar 
(rigor mortis). Para a produção de mais energia, o glicogênio muscular é utilizado. A glicogênese pode ocorrer de forma anaeróbica, realizada através da conversão do glicogênio em ácido pirúvico que se converte em ácido lático (NELSON; COX, 2008). Este ácido lático não tem como circular sem a corrente sanguínea e, então, fica preso no músculo do animal, causando a queda do pH. Dessa forma, a quantidade de glicogênio armazenado no músculo no pré-abate é altamente correlacionado com o pH final da carne (BENDALL, 1973), que, normalmente, está entre próximo a 5,7 (BRIDI,2009).

Sob estresse prolongado, os animais têm sua reserva de glicogênio muscular diminuída, o que irá reduzir a acidificação da carne após 24 horas de abate. Animais com pH acima de 6,0, após 24 horas de abate apresentam um problema de qualidade de carne chamado DFD (em inglês, Dark, Firm and Dry - carne de cor escura, textura firme e com retenção de líquidos no seu interior. RAMOS; GOMILDE, 2012). Com pH elevado, a água se liga com mais facilidade às miofibrilas, aumentando a capacidade de retenção de água da carne (baixa perda de água por gotejamento - drip loss). Dessa forma, a luz é pouco refletida, dando à carne uma aparência escurecida.

Quando o animal sofre demasiado estresse no pré-abate, seja de origem emocional ou ambiental, a carne pode apresentar um problema de qualidade conhecido como PSE (em inglês, Pale, Soft and Exsudative - cor pálida, textura mole e com exsudação de líquidos. RAMOS; GOMILDE, 2012). Isso ocorre porque o $\mathrm{pH}$ diminui de forma drástica nas primeiras horas após o abate, quando o músculo ainda está quente. Com pH diminuído, o líquido intracelular é expulso de dentro das miofibrilas, e, consequentemente, a carne tem baixa capacidade de retenção de líquido (alta porcentagem de drip loss. WISMER-PEDERSEN, 1987). Para aferir rapidamente a qualidade de carne, observa-se a cor ( $L^{*}, a^{*}$ e $\left.b^{*}\right)$, o pH inicial, o pH final e o drip loss (BRIDI, 2009). Através desses valores, pode-se separar as carnes em PSE, DFD ou Normal (Tabela 1).

Tabela 1 - Classificação da carne suína em Normal, PSE e DFD (adaptado de Bridi, 2009).

\begin{tabular}{lcccc}
\hline & $\mathrm{pH}$ inicial & $\mathrm{pH}$ final & Cor $\mathrm{L}^{*}$ & Drip loss \\
\hline Normal & $\geq 5,8$ & $<6,0$ & Entre 43 e 49 & $<5 \%$ \\
PSE & $<5,8$ & $\leq 5,6$ & $>50$ & $>5 \%$ \\
DFD & - & $>6,0$ & $<42$ & $<5 \%$ \\
\hline
\end{tabular}


Além destas variáveis, pode-se, também, utilizar outros fatores para avaliar a qualidade da carne como marmoreio, perda de água por exsudação, força de cisalhamento e análise dos microelementos presentes na carne. Variáveis relacionadas ao rendimento de carcaça também podem ser analisadas, como comprimento de carcaça, perda por resfriamento, espessura de toicinho, área de olho de lombo, rendimento de carcaça (BRIDI, 2009). 


\section{OBJETIVOS}

\subsection{OBJETIVO GERAL}

Comparar os parâmetros comportamentais indicativos de estresse, a qualidade da carne e a influência do enriquecimento ambiental em leitões criados no sistema intensivo confinado, de acordo com a qualidade dos tratamentos recebidos desde o nascimento ao abate: aversivo, misto ou controle.

\subsection{OBJETIVOS ESPECÍFICOS}

- Verificar a resposta comportamental e a capacidade de lidar com os estressores quando os leitões são expostos a um tratamento aversivo durante todas as fases de criação;

- Verificar se animais tratados aversivamente apenas nas fases de maternidade e creche têm dificuldade de responder a novos estressores quando mais velhos;

- Comparar o padrão comportamental de suínos criados de forma aversiva ou neutra (controle) em cada mudança de ambiente (maternidade-creche, creche-crescimento/ terminação);

- Determinar se leitões podem discriminar e recordar dos manejadores habituais;

- Verificar se o enriquecimento ambiental tem influência sobre o desempenho dos animais, de acordo com o tratamento recebido (controle, misto ou aversivo);

- Comparar o padrão comportamental de suínos com ou sem enriquecimento ambiental, de acordo com o tratamento recebido;

- Averiguar as diferenças nas variáveis medidas para aferir a qualidade de carne de suínos que receberam tratamento controle ou aversivo. 


\section{HIPÓTESES}

- Leitões tratados aversivamente, tanto nas fases iniciais quanto em todo o ciclo de criação, demonstrarão maior frequência de comportamentos indicativos de estresse quando expostos a novas situações estressantes;

- Animais com enriquecimento ambiental terão melhor desempenho, do que os animais que não receberam enriquecimento ambiental, dentro do mesmo tratamento;

- A qualidade da carne de suínos tratados aversivamente será prejudicada. 


\section{METODOLOGIA GERAL}

As próximas seções tratam do experimento realizado com os mesmos animais, sendo que houve a divisória em seções diferentes de acordo com o tema estudado. A Metodologia Geral contém a metodologia usada para criação, preparação e tratamento dos animais. Cada seção conta com sua metodologia específica com a finalidade de facilitar o entendimento deste trabalho.

\subsection{LOCAL}

O experimento foi realizado nas instalações da Faculdade de Zootecnia e Engenharia de Alimentos (FZEA) e da Faculdade de Medicina Veterinária e Zootecnia (FMVZ) da

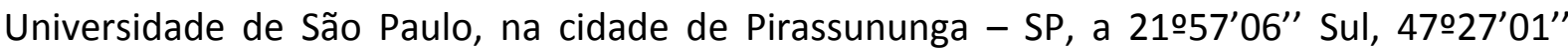
Oeste e 597 metros de altitude. A criação dos animais ocorreu nas dependências da Suinocultura Experimental da FMVZ, entre os meses de outubro de 2013 a março de 2014, com temperaturas médias do ar máximas de $28,7 \pm 1,3$ e mínimas de $19,4 \pm 1,5$ com umidade relativa do ar média de $74,1 \pm 3,2$. O abate dos animais foi realizado nas dependências do Matadouro Escola do Campus da Universidade de São Paulo, em Pirassununga e as análises de qualidade de carne, no Laboratório de Avaliação e Qualidade de Carne da FZEA. As imagens dos comportamentos e testes comportamentais foram analisadas no Laboratório de Biometeorologia e Etologia da FZEA. As análises do sangue colhido durante o abate foram realizadas em laboratório comercial situado na cidade de Pirassununga, SP.

\subsection{ANIMAIS}

Quinze fêmeas F1 (Landrace $\times$ Large White) foram inseminadas artificialmente com sêmen de machos Agroceres AGPIC 415 (Pietran $\times$ Linha 65 sintética - Pietran $\times$ Duroc $\times$ Landrace). Dos leitões nascidos, 144 foram utilizados para formar três grupos, sendo que cada grupo recebeu um tratamento diferente. Cada grupo era composto por 16 baias com três animais em cada baia, totalizando 48 leitões por tratamento. 


\subsection{INSTALAÇÕES E MANEJO}

Uma semana antes da data prevista de parto, as fêmeas foram alojadas nas salas de maternidade. As baias de maternidade mediam 2,2 ×1,5 m (comprimento x largura), onde a porca tinha seus movimentos restritos por uma cela de $2,2 \times 0,6 \times 1,0 \mathrm{~m}$ (comprimento $\times$ largura $\times$ altura. Figura 3). A escolha das fêmeas foi feita de forma aleatória e ao acaso, onde as 15 porcas formaram três grupos de cinco animais. Cada grupo foi alojado numa sala e cada sala recebeu um tratamento diferente (os tratamentos estão expostos no item 5.4 desta seção). Durante todas as fases, os animais receberam ventilação natural.

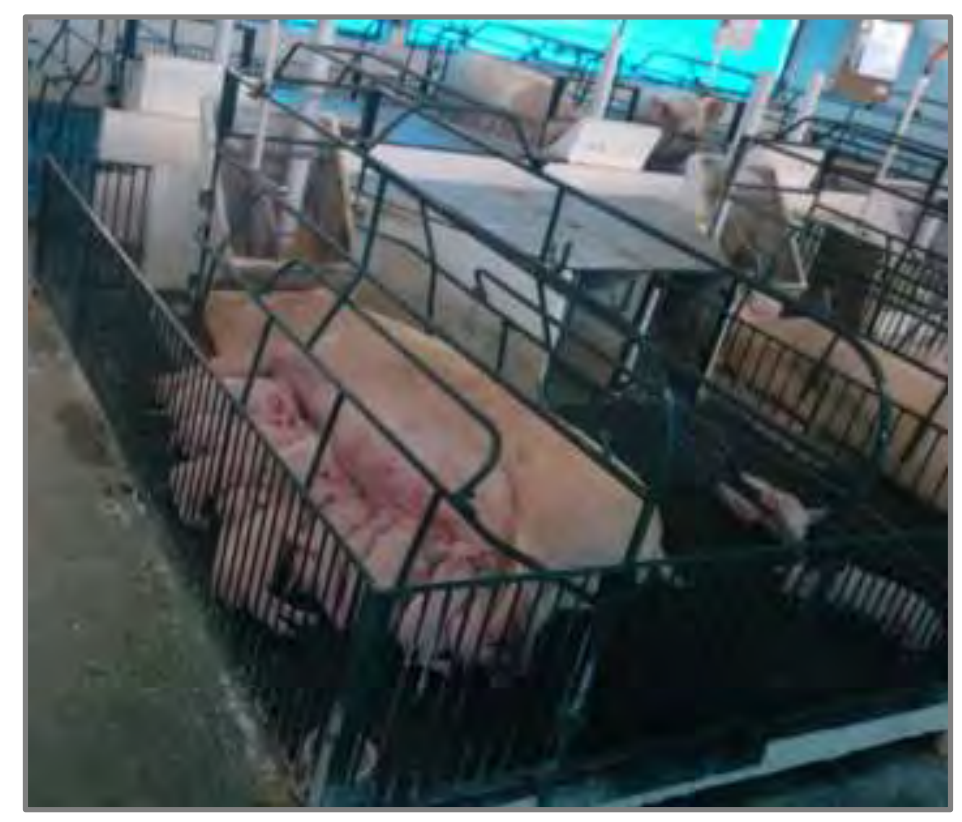

Figura 3: Instalações da sala de maternidade.

Os partos aconteceram nos dias 11, 12, 13 e 14 de outubro de 2013 e foram sincronizados utilizando $1 \mathrm{ml}$ de PGF2a intravulvar, um dia antes da data provável do parto. Todos os partos foram assistidos por profissionais que interviram quando necessário (Figura 4). As 15 porcas pariram um total de 198 leitões vivos, 16 natimortos e 10 mumificados. Até o desmame houve perda de 14 leitões (4,16\% de mortalidade durante a maternidade). Assim que nasciam, a placenta era retirada dos leitões, o umbigo era amarrado e curado em iodo $2 \%$ e, então, os animais eram secos em pó secante próprio para esta ação. Após o último 
leitão da leitegada nascer, todos os leitões eram colocados para mamar o colostro da porca. Quando necessário, os leitões foram transferidos de porca e não houve rejeição.

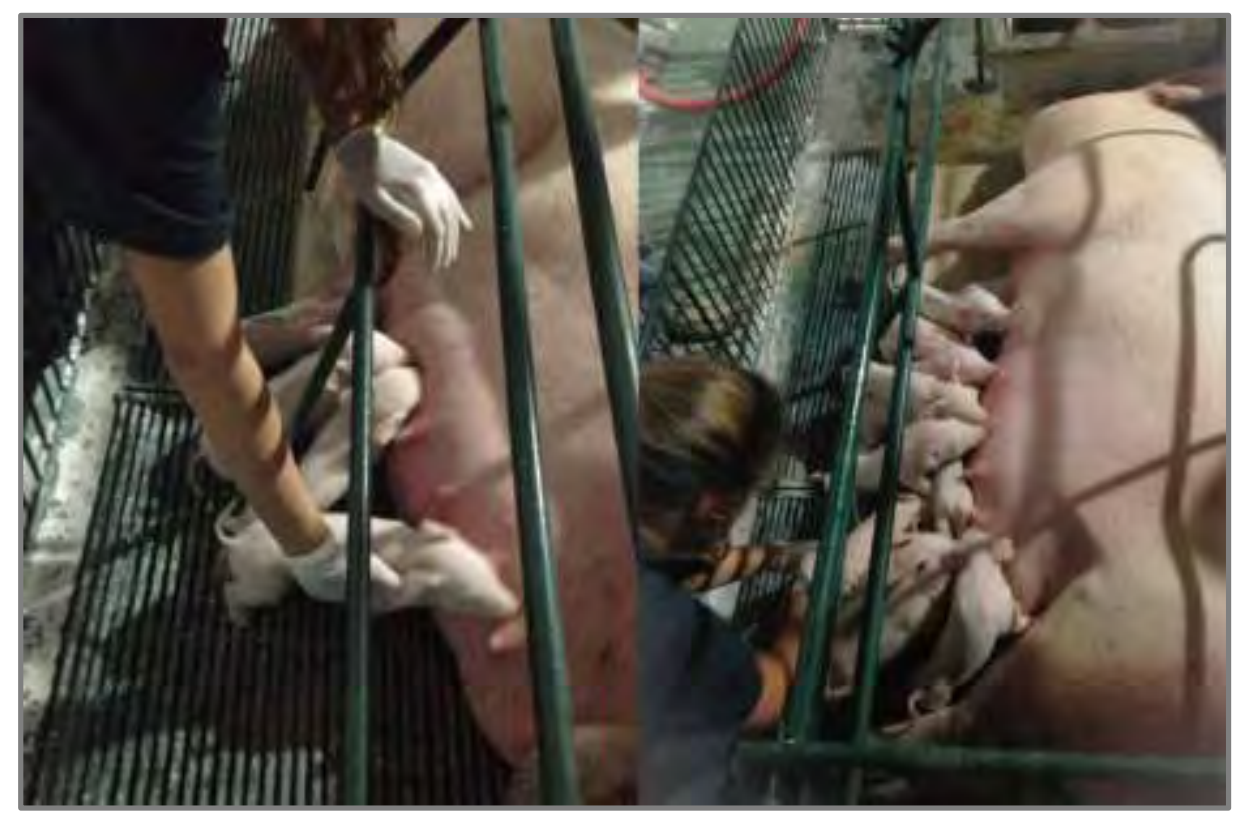

Figura 4: Leitões sendo auxiliados para mamar o colostro.

No segundo dia de vida, os leitões receberam uma dose de ferro intramuscular, foram submetidos à pesagem individual, receberam identificação através de brincos do tipo TAG e tiveram seus dentes desgastados para evitar lesões nos tetos da porca e lesões entre os leitões da mesma leitegada. Os machos não foram castrados durante a fase de maternidade: receberam imunocastração (Vivax ${ }^{\circledR}$ - Pfizer Ltda.) em duas doses, sendo a primeira no final da creche e a segunda próxima da quarta semana antes do abate.

Para os leitões foi disponibilizado um escamoteador com piso aquecido desde o dia do nascimento até o dia do desmame. Eles tinham água à vontade através de um bebedouro do tipo chupeta e, a partir do 14으 dia de vida, começaram a receber ração pré-inicial (3360 Kcal.kg ${ }^{-1}$ EM e $18 \%$ PB. Figura 5) oferecida em comedouro manual, inacessível à porca. 0 consumo dos leitões neste período não foi aferido, pois o propósito da oferta da ração préinicial era familiarizar os leitões ao alimento sólido. As porcas receberam ração ad libitum específica para porcas lactantes (3300 Kcal. $\mathrm{kg}^{-1} \mathrm{EM}$ e $\left.18 \% \mathrm{~PB}\right)$ e tinham acesso à água através 
de um bebedouro tipo chupeta. Durante todas as fases de criação, a iluminação e temperatura ambiente eram naturais e a higienização das baias acontecia diariamente.

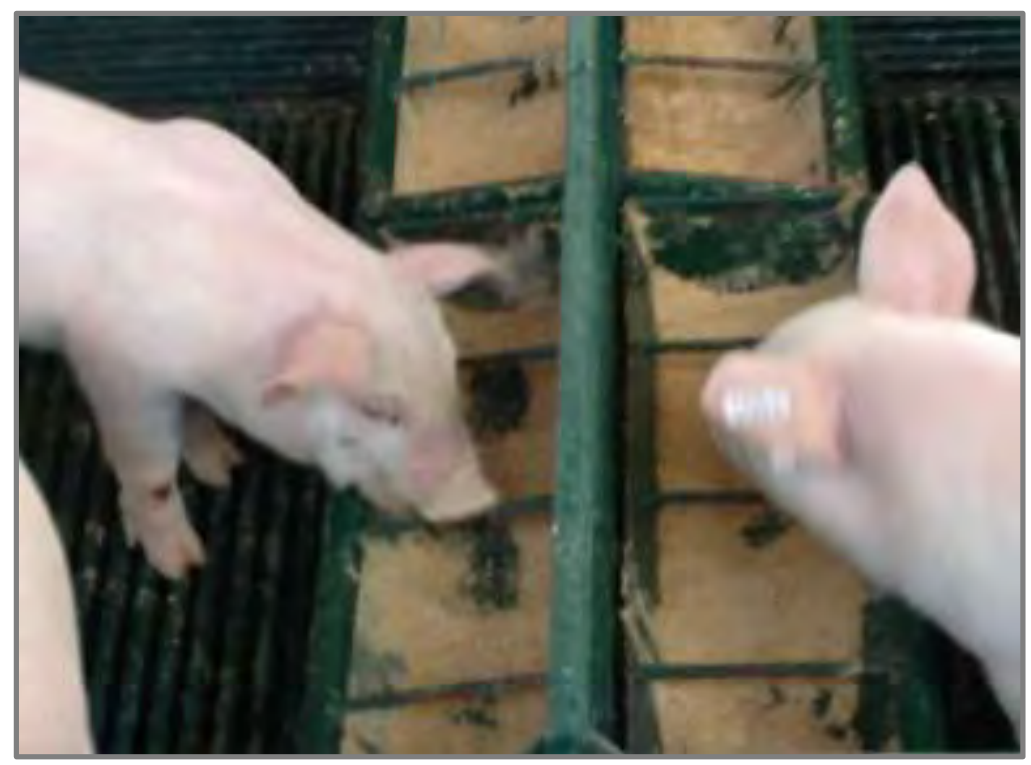

Figura 5: Ração pré-inicial oferecida aos leitões a partir do 14ㅇ dia de vida.

Ao $14^{\circ}$ dia de vida, todos os leitões foram vacinados contra ielíte (Enterisol lleitis ${ }^{\circledR}$ ) e contra colibacilose neonatal $\left(\operatorname{Porcilis}^{\circledR}\right)$. No 21 o dia de vida, receberam vacina contra circovirus suíno (Suvaxyn ${ }^{\circledR}$ ) e conta pneumonias (Respisure ${ }^{\circledR}$ ).

Os animais foram desmamados com $26,38 \pm 0,86$ dias de idade, no dia 08 de novembro de 2013 , no período da manhã. Neste manejo, as porcas foram retiradas das salas de maternidade a priori. Os leitões foram pesados individualmente e os grupos foram formados por três animais da mesma leitegada, escolhidos de forma aleatória, porém homogênea com relação ao peso, mas indiferente com relação ao sexo do animal.

O dia do desmame foi considerado como o 28ㅇ dia de vida dos animais, desta forma, a fase de creche aconteceu entre o $28^{\circ}$ e 70 ㅇ dia. Durante o período de creche os animais receberam três rações diferentes, dispostas em comedouro manual: pré-inicial (do dia 08 a 17 de novembro de 2013 - 3360 Kcal.kg-1 EM e 18\% PB), inicial I (do dia 18 de novembro ao dia 03 de dezembro de 2013 - 3300 Kcal. $\mathrm{kg}^{-1}$ EM e 16\% PB) e inicial II (do dia 02 a 20 de dezembro de 2013 - 3300 Kcal.kg-1 EM e 16\% PB). Durante todo o período receberam água 
fresca através de bebedouro tipo chupeta e aquecimento ambiental durante as noites, quando necessário, através de aquecedores a gás. O piso era elevado, sendo metade ripado e metade de cimento (Figura 6). Nesta fase, alguns animais apresentaram diarreia e foram medicados com enrofloxacina intramuscular durante três dias consecutivos. Não houve mortalidade.

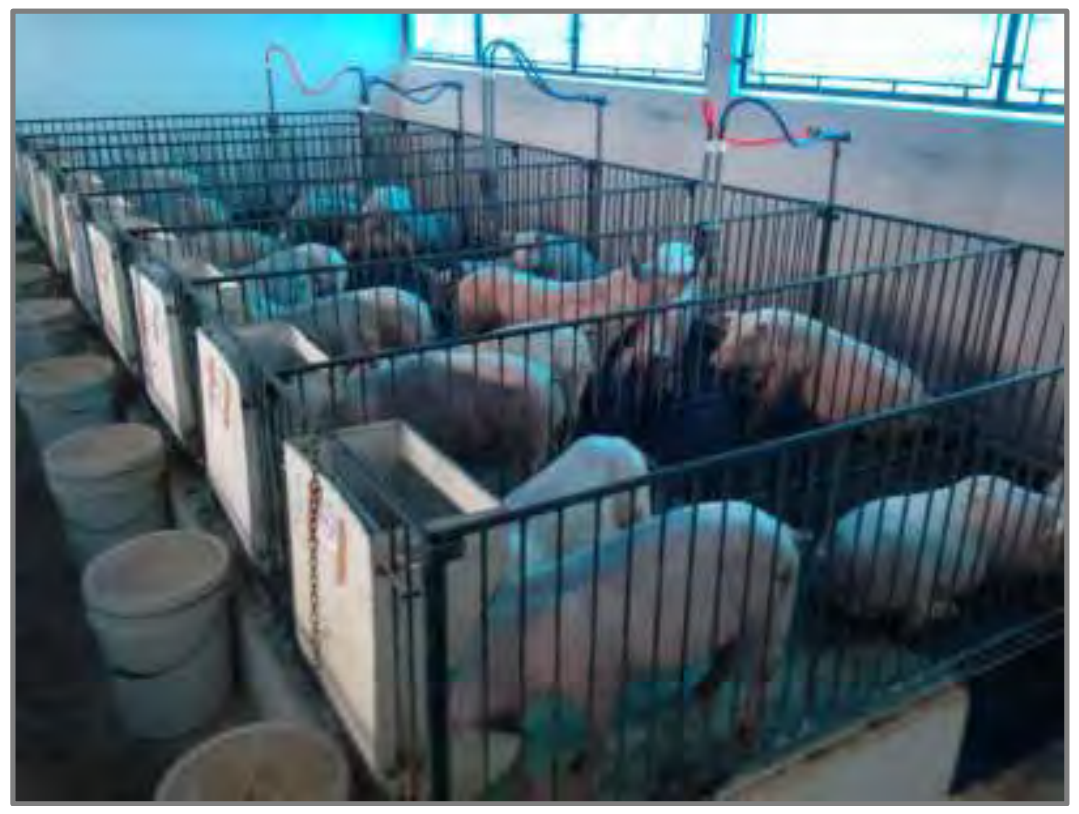

Figura 6: Instalações da sala de creche.

No final do período de creche, no dia 20 de novembro de 2013, os animais foram pesados e o consumo de ração foi anotado. Logo após, foram transferidos para as salas de crescimento/terminação, sempre mantendo os mesmos grupos de três animais com os quais eles dividiam baia desde o desmame. Do dia da transferência até o dia 03 de fevereiro de 2014, os animais receberam ração de crescimento (3280 Kcal. $\mathrm{kg}^{-1} \mathrm{EM}$ e $15 \% \mathrm{~PB}$ ) à vontade, disposta em comedouro manual. Após este período até o abate, os animais receberam ração de terminação (3250 Kcal. $\mathrm{kg}^{-1} \mathrm{EM}$ e 13\% PB). Sempre tiveram água à vontade e uma lâmina d'água para realizar termólise (Figura 7).

A partir da fase de crescimento, metade dos animais de cada tratamento recebeu uma forma de enriquecimento ambiental, dado logo após o tratamento da manhã. Os enriquecimentos eram um balde com serragem de madeira com uvas passas distribuído pelo 
chão, abóboras em pedaços, maçã ou brinquedo feito com cano de PVC com orifícios por onde saiam uvas passas que estavam no interior do brinquedo. Os enriquecimentos foram escolhidos de acordo com as especificações de Studnitz et al. (2007), que afirma que o enriquecimento, para ser interessante para o suíno, deve ser complexo, mutável, destrutível, manipulável e comestível. Estes enriquecimentos eram oferecidos de forma aleatória para evitar a habituação dos animais. Os animais que recebiam o enriquecimento eram sempre os mesmos (mesmas baias) e os animais que não recebiam, nunca tiveram contato com o enriquecimento.

Os animais receberam imunocastração em duas doses: no dia 12 de dezembro de 2013 e 21 de janeiro de 2014. Quando houve mudança de ração, os animais foram pesados e o consumo de ração foi anotado. Durante o período de crescimento/terminação os animais receberam ventilação natural. No dia anterior ao abate, os animais foram submetidos à pesagem e sofreram 18 horas de jejum sólido, mas tinham acesso a água de boa qualidade.

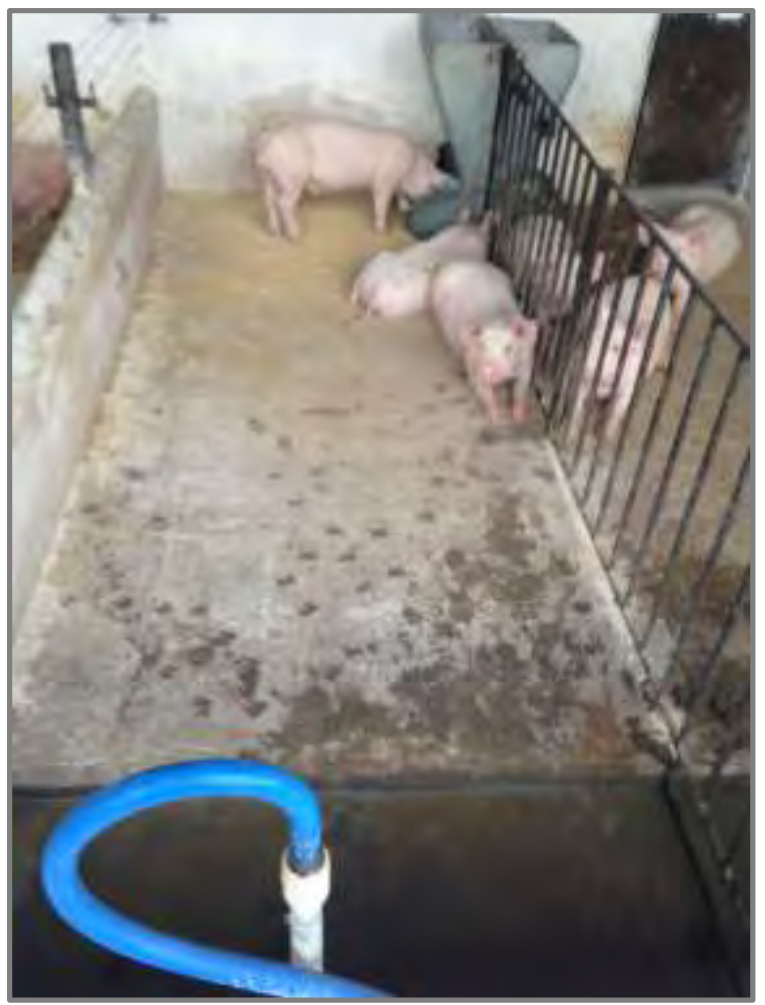

Figura 7: Instalações da sala de crescimento/terminação. 


\subsection{TRATAMENTOS}

Os tratamentos tiveram início no 10 ㅇa dia de vida dos leitões, onde cada grupo recebeu um dos três tratamentos:

1) Tratamento Aversivo (TA): a pessoa responsável pelo tratamento dirigiu-se aos leitões de forma rude, utilizando tom de voz agressivo, fazendo ameaças posturais e empurrando os animais, sem bater neles.

2) Tratamento Controle (TC): a pessoa responsável pelo tratamento foi cuidadosa ao se movimentar e usou tom de voz suave, apenas quando necessário. Este tratamento não tinha como finalidade ser um tratamento positivo, mas ser diferente do tratamento aversivo, com o mínimo de contato entre a pessoa responsável e os animais.

3) Tratamento Misto (TM): os animais foram tratados de acordo com TA durante as fases de maternidade e creche e foram tratados de acordo com TC durante as fases de crescimento e terminação. Este tratamento teve a finalidade de verificar se os animais sofreriam estresse residual em eventos futuros potencialmente estressantes.

Durante o embarque e o transporte para o abate, todos os animais receberam TC, realizado pelos profissionais responsáveis por este manejo dentro do Matadouro Escola.

Um esquema de como foram realizados os tratamentos e por quem foram realizados, está disposto na Figura 8. A pessoa responsável pelo TA durante todo o período de vida dos animais era a mesma pessoa que fez o tratamento para TC durante todo o período de vida dos animais e para TM na primeira fase (aversiva). Esta pessoa era uma mulher que vestiu sempre um macacão laranja e botas pretas (Figura 9). O tratamento começava sempre por TC para evitar que qualquer tipo de mudança de humor do tratador após realizar o TA influenciasse no tratamento de TC. A pessoa responsável por TM na segunda fase (controle) era outra mulher, até então desconhecida aos animais, que trajava um macacão azul escuro e botas pretas (Figura 9).

Cada sala era separada por parede de concreto, onde um tratamento não influenciava o tratamento da sala vizinha. Os tratamentos foram realizados em todas as fases de vida dos animais, duas vezes ao dia (manhã e tarde), dispostos da seguinte maneira: 
diariamente, na fase de maternidade; em dias alternados, durante a fase de creche; a cada dois dias, nas fases de crescimento e terminação. Durante o tratamento os animais eram arraçoados e as instalações eram limpas. Nos dias em que não havia tratamento, as pessoas responsáveis pelo manejo diário da granja faziam o manejo de limpeza e arraçoamento dos animais de forma neutra (evitando contato direto com os animais).

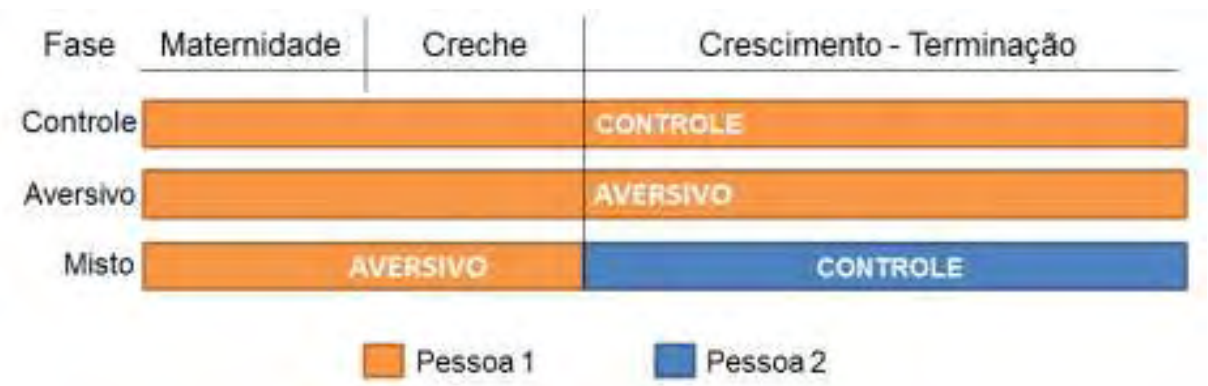

Figura 8: Esquema temporal de realização dos tratamentos. Durante as fases de creche e maternidade os tratamentos foram realizados pela Pessoa 1 que sempre trajava macacão laranja. Durante a fase de crescimento/terminação, os tratamentos foram realizados pela pessoa 1 (macacão laranja) para os grupos controle e aversivo, e pela pessoa 2 (macacão azul) para o grupo misto.

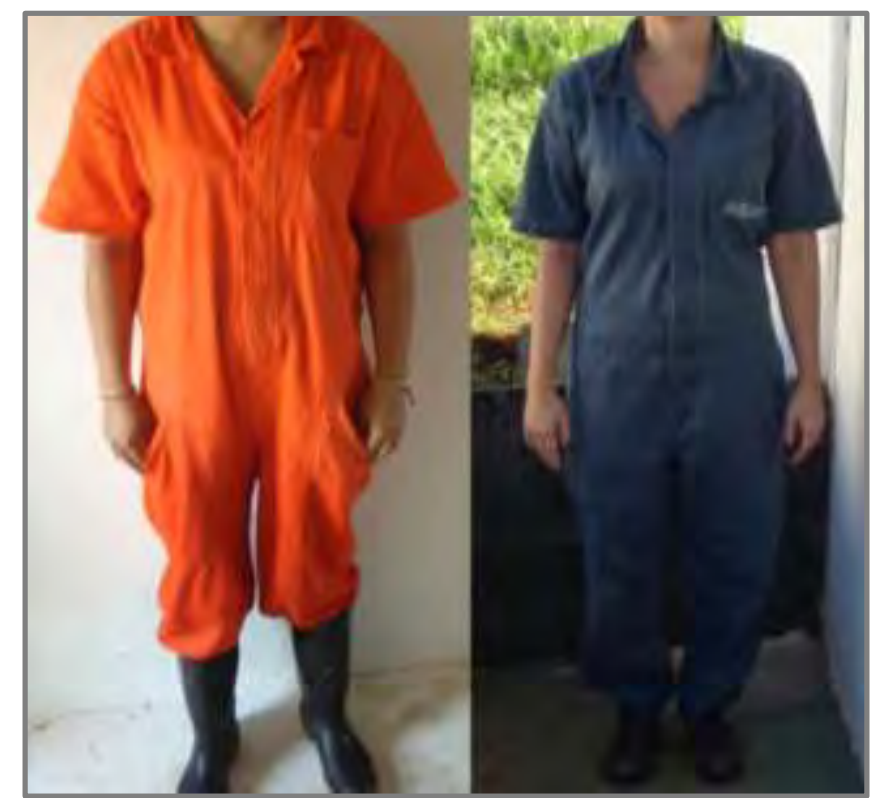

Figura 9: Esquerda: roupa laranja do tratador habitual do tratamento controle, tratamento aversivo e primeira fase do tratamento misto (aversivo). Direita: roupa azul do tratador habitual da segunda fase do tratamento misto (controle). 


\subsection{ABATE}

O abate aconteceu nos dias 10 e 11 de março de 2014, quando os animais tinham 150 dias. Para a colheita de amostras para a qualidade da carne, 48 animais (fêmeas e machos) de cada tratamento (sendo metade composta por animais que receberam enriquecimento ambiental e metade não) foram escolhidos ao acaso. $\mathrm{O}$ abate ocorreu nas dependências do Matadouro do Campus de Pirassununga. Foi utilizada insensibilização através de choque e posterior sangria para abater os animais.

\subsection{ANÁLISE ESTATÍSTICA DOS DADOS}

O delineamento experimental utilizado foi o inteiramente casualizado (DIC) tendo um fatorial $3 \times 2$ como o esquema de distribuição dos tratamentos controle (TC), misto (TM) e aversivo (TA) combinando com a presença de enriquecimento ambiental ou não. Todas as análises foram realizadas através do pacote estatístico Statistical Analysis System, versão 9.1.

Para a análise dos dados de comportamento e dos testes comportamentais (Teste de Aproximação Humana, Teste de Área Desconhecida e Teste de Novo Objeto), foram realizadas análises exploratórias com o propósito de caracterizar a forma de distribuição dos dados e as fontes de variação mais relevantes. A partir destes resultados, foi utilizado o modelo ajustado através da teoria de modelos lineares generalizados, utilizando-se o procedimento GLM do software SAS. Para avaliação das variáveis comportamentais e dos testes, a partir das porcentagens das frequências de ocorrência das diferentes variáveis categóricas relacionadas ao etograma de trabalho, foi realizada a transformação de escala dos dados para "arco-seno raiz de porcentagem", procedendo-se à análise de variância. Para apresentação dos resultados os dados foram retornados à escala original. O modelo estatístico para comportamento na fase de maternidade contemplou o efeito fixo de tratamento (controle e aversivo), com posterior comparação de médias. Na fase de creche, os efeitos fixos contemplados foram de dia (desmame, dia 2, dia 3 e último dia de creche) e tratamento (controle e aversivo), assim como suas interações, com posterior comparação de médias. Na fase de crescimento/terminação foram contemplados os efeitos fixos de dia (dias 1, 2 e 3) e tratamento (controle, misto e aversivo), assim como suas interações, com 
posterior comparação de médias. Para os comportamentos do dia pré-abate, o modelo contemplou os efeitos fixos de tratamento (controle, misto e aversivo) e enriquecimento (com ou sem), assim como suas interações, com posterior comparação de médias. Para o Teste de Aproximação Humana, o modelo contemplou o efeito fixo de tratamento (controle, misto e aversivo), com posterior comparação de médias. Para o Teste de Área Desconhecida, foram contemplados os efeitos fixos de tratamento (controle e aversivo), de dia (dias 1 e 2 ) e de minuto (minutos 1, 2, 3, 4 e 5), assim como suas interações, com posterior comparação de médias. Para o Teste de Novo Objeto, foram contemplados os efeitos fixos de tratamento (controle e aversivo), de dia (dia 1 e dia 2) e de minuto (minutos 1, 2, 3), assim como suas interações, com posterior comparação de médias. Todas as médias foram comparadas pelo teste $\mathrm{F}$ e teste t de Student (PDIFF).

Para as análises dos dados de desempenho, qualidade de carne e indicadores sanguíneos de estresse foi realizada análise de variância (MIXED - SAS). Para a análise de ganho de peso diário e conversão alimentar o modelo contemplou os efeitos fixos de tratamento (controle, aversivo e misto), sexo (macho e fêmea) e fase de criação (creche, crescimento, terminação e pré-abate), assim como suas interações. Para as variáveis de qualidade de carne, o modelo contemplou os efeitos fixos de tratamento (controle, misto e aversivo) e de enriquecimento (com ou sem), assim como suas interações. Nos indicadores sanguíneos de estresse, para as análises de cortisol e creatina-fosfoquinase, o modelo contemplou os efeitos fixos de tratamento (controle, misto e aversivo) e enriquecimento (com ou sem), assim como suas interações; para a análise de lactato, o modelo contemplou os efeitos fixos de tratamento (controle, misto e aversivo) e fase de criação (desmame, creche-crescimento, pré-abate e abate), assim como suas interações. Todas as médias foram comparadas pelo teste $\mathrm{F}$ e teste $\mathrm{t}$ de Student (PDIFF).

\subsection{CONSELHO DE ÉTICA}

O projeto de doutorado foi submetido ao Comitê de Ética em Pesquisa (CEP) da FZEA/USP, CEUA-FZEA, e teve parecer referenciado, no dia 13 de setembro de 2012 (Processo USP $n^{\circ}:$ 2012.1.938.74.6). 


\section{EFEITO DA QUALIDADE DO TRATAMENTO, DO NASCIMENTO AO ABATE, SOBRE O DESEMPENHO E COMPORTAMENTO DE SUÍNOS}

Dentro da produção de suínos, o tratador tende a estar presente e próximo do animal, pelo menos nas produções nacional onde a maioria é composta por produção familiar. Este contato direto e diário entre animais e tratador pode influenciar diretamente o padrão comportamental dos suínos (BOKKERS, 2006).

Já nos primeiros dias de vida do leitão, ele corre perigo. O esmagamento de leitões normalmente acontece quando a porca muda de posição - quando vai deitar ou quando rola para mudar de decúbito (WEARY; LAWSON; THOMPSON, 1996; DAMM; FORKMAN; PEDERSEN, 2005). Na vida natural, porcas tendem a permanecerem inativas nas primeiras 48 horas pós-parto, provavelmente para evitar o esmagamento de leitões e permitir que eles estabeleçam a ordem da teta (PETERSEN; RÉCEN; VESTERGAARD, 1990). Nesta condição, as porcas procuram onde estão os leitões antes de se deitar e os empurram com o focinho para que não os esmaguem. Porcas criadas em celas não conseguem ter visão de todo seu corpo, apenas da região da cabeça, e podem esmagar os leitões ao se deitarem sem ver o que estão fazendo (JOHNSON; MARCHANT-FORDE, 2009).

Com quatro semanas de idade, animais sob confinamento sofrem com o desmame abrupto e precoce (WEARY; APPLEBY; FRASER, 1999; HÖTZEL et al., 2010). Estes animais costumam ter maior frequência de comportamentos indicativos de estresse, como aumento de vocalização (WEARY; APPLEBY; FRASER, 1999; COLSON et al., 2006), comportamentos anormais (GONYOU et al., 1998; WEARY; APPLEBY; FRASER, 1999; WOROBEC; DUNCAN; WIDOWSKI, 1999), tentativa de fuga (WOROBEC; DUNCAN; WIDOWSKI, 1999; HÖTZEL et al., 2010), interação agonística (JARVIS et al., 2008; DEVILLERS; FARMER, 2009) e diminuição do consumo de ração (GONYOU et al., 1998; VAN DER MEULEN et al., 2010), podendo ser agravados pela qualidade do tratamento dado aos animais (SOMMAVILLA; HÖTZEL; DALLA COSTA, 2011).

Leitões com quatro semanas de idade, em vida natural, tendem a seguir a porca para forragear e, assim, começam a estabelecer contato social com os demais membros do grupo 
em que vivem ( $D^{\prime} E A T H ;$ TURNER, 2009). Tendo mais contato com outros indivíduos do grupo, os leitões desta idade demonstram grande frequência de brincadeiras (NEWBERRY et al., 1988), além de gastarem boa parte do seu tempo repousando (JENSEN, 1986). Estes animais ainda dependem do leite materno como fonte de nutrição, apesar de estarem começando a aprender como se alimentar de sólidos (PETERSEN; VESTERGAARD; JENSEN, 1989).

Depois do desmame, leitões confinados comumente sofrem mistura de leitegadas para a formação de lotes semelhantes e facilitar o manejo. Também são transferidos para salas diferentes das que estavam acostumados, tendo que se adaptar ao novo ambiente imposto a eles. Somado a isso, eles perdem a companhia da mãe (e do grupo social préestabelecido entre os irmãos) e perdem sua principal fonte de alimentação: o leite (PAJOR; FRASER; KRAMER, 1991). Sendo assim, o desmame é um evento importante e estressante na vida dos leitões (BROOM; FRASER, 2007). Além disso, nos demais dias de vida dos leitões, eles costumam enfrentar batalhas diárias com outros membros do grupo, variação de temperatura ambiental, superlotação, competição por um lugar ao comedouro, manejos veterinários aversivos e doenças. A presença de um tratador aversivo pode piorar a resposta dos animais a estas situações, pondo em risco o sucesso da produção e do bem-estar animal (SOMMAVILLA; HÖTZEL; DALLA COSTA, 2011).

Desta forma, objetivou-se comparar o desempenho de leitões que receberam tratamento controle ou aversivo, verificando a resposta comportamental e a capacidade de lidar com estressores (como a mudança de ambiente) quando os animais são expostos a um tratamento aversivo durante toda a vida ou apenas nas primeiras fases de vida (maternidade e creche). Objetivou-se, também, comparar o padrão comportamental de suínos criados de forma aversiva ou controle (neutra) em cada mudança de ambiente (maternidade para creche; creche para crescimento/terminação). Esperava-se que leitões tratados de forma aversiva durante toda a vida demonstrassem maior frequência dos comportamentos indicativos de estresse e que leitões tratados de forma aversiva apenas nas fases de maternidade e creche, demonstrassem maior frequência de comportamento indicativo de estresse quando expostos a novas situações estressantes. 


\subsection{METODOLOGIA}

\subsubsection{Desempenho}

As mortalidades durante a fase de maternidade foram anotadas, juntamente com a causa da morte dos leitões. Os animais foram pesados no dia do nascimento, no desmame, no início da fase de crescimento, no início da fase de terminação e no pré-abate.

O consumo de ração foi pesado a cada mudança de ração (pré-inicial I e II e inicial na fase de creche, crescimento na fase de crescimento; recria na fase de terminação) e o valor foi encontrado através da subtração da ração oferecida pela sobra de ração no comedouro, dividido por três (número de leitões por baia). A conversão alimentar e o ganho de peso diário foram calculados segundo as seguintes fórmulas:

$$
\text { Conversão alimentar }=\frac{\mathrm{Kg} \text { de ração consumida por animal }}{\text { Ganho de peso do animal no período }}
$$

Ganho de peso diário $=$ Ganho de peso do animal no período

Número de dias do período

\subsubsection{Observação do comportamento dos animais}

Os comportamentos foram filmados para posterior análise, com a finalidade de evitar interferência do observador no comportamento dos animais. Os dois observadores eram pessoas treinadas e calibradas previamente para garantir a confiabilidade dos resultados e desconheciam o tratamento dos animais que estavam observando. As observações foram realizadas nas trocas de ambiente (maternidade-creche; crechecrescimento/terminação). Foi filmado o comportamento no dia antes da troca de ambiente, no dia da troca de ambiente e nos dois dias subsequentes. Foram observadas 6 horas diárias consecutivas, em instantâneos com intervalo de 5 minutos para cada observação (72 observações por animal por dia). Os comportamentos observados durante a maternidade, creche e crescimento/terminação estão dispostos no Etograma de Trabalho (Tabela 2), juntamente com suas definições. 
Tabela 2 - Etograma de Trabalho: comportamentos observados durante as fases de maternidade $(M)$, creche $(C)$, crescimento/terminação $(C / T)$ e suas definições.

\begin{tabular}{|c|c|c|c|c|}
\hline \multirow{2}{*}{$\begin{array}{l}\text { Comportamentos } \\
\text { Observados }\end{array}$} & \multirow{2}{*}{ Definição dos comportamentos } & \multicolumn{3}{|c|}{ Fase } \\
\hline & & $\mathbf{M}$ & C & $\mathrm{C} / \mathrm{T}$ \\
\hline $\begin{array}{l}\text { Comportamento de } \\
\text { amamentação }\end{array}$ & $\begin{array}{l}\text { Em posição de mamar, com a boca em contato } \\
\text { com o teto da mãe, sugando ou massageando o } \\
\text { úbere. }\end{array}$ & $x$ & & \\
\hline No comedouro & $\begin{array}{l}\text { Com a cabeça dentro do comedouro, com a boca } \\
\text { em contato com a ração. }\end{array}$ & $x$ & $\mathrm{x}$ & $X$ \\
\hline No bebedouro & $\begin{array}{l}\text { Com a boca em contato com a chupeta do } \\
\text { bebedouro. }\end{array}$ & $x$ & $\mathrm{x}$ & $x$ \\
\hline Interação agonística & $\begin{array}{l}\text { Agredindo ou sendo agredido por outro leitão, } \\
\text { mordendo, empurrando outro animal de forma } \\
\text { agressiva ou em retaliação a um ataque agressivo. }\end{array}$ & $x$ & $\mathrm{x}$ & $\mathrm{X}$ \\
\hline Interagindo com a mãe & Em contato com a porca, de forma positiva. & $x$ & & \\
\hline $\begin{array}{l}\text { Interação positiva com } \\
\text { os irmãos }\end{array}$ & $\begin{array}{l}\text { Em contato com outros leitões da mesma } \\
\text { leitegada, de forma positiva, excetuando-se } \\
\text { brincadeiras. }\end{array}$ & $x$ & & \\
\hline Brincando & $\begin{array}{l}\text { Brincando sozinho, correndo, chacoalhando a } \\
\text { cabeça, brincando com outro leitão. }\end{array}$ & $x$ & $x$ & $\mathrm{x}$ \\
\hline Fuçando/Explorando & $\begin{array}{l}\text { Em atividade exploratória, com o focinho em } \\
\text { contato com o chão ou instalações, ou andando } \\
\text { com a cabeça baixa e nariz em contato com o chão. }\end{array}$ & $x$ & $x$ & $\mathrm{x}$ \\
\hline Repousando & $\begin{array}{l}\text { Em pé parado, inativo, deitado ou dormindo, sem } \\
\text { realizar nenhuma atividade. }\end{array}$ & $x$ & $x$ & $\mathrm{X}$ \\
\hline No escamoteador & $\begin{array}{l}\text { Dentro do escamoteador, fora do campo de visão } \\
\text { da câmera filmadora. }\end{array}$ & $x$ & & \\
\hline Tentativa de fuga & $\begin{array}{l}\text { Investindo contra as grades da baia, apoiando as } \\
\text { patas dianteiras na cela ou saltando em direção às } \\
\text { bordas da baia, na tentativa de escapar. }\end{array}$ & & $x$ & $\mathrm{X}$ \\
\hline Belly-nosing & $\begin{array}{l}\text { Comportamentos oro-nasais direcionados ao } \\
\text { umbigo, flanco, prepúcio ou ventre de membros da } \\
\text { leitegada. }\end{array}$ & & $x$ & $\mathrm{x}$ \\
\hline Na lâmina d'água & $\begin{array}{l}\text { Com as quatro patas dentro da lâmina d'água, } \\
\text { deitado ou em pé. }\end{array}$ & & & $\mathrm{X}$ \\
\hline Outros & $\begin{array}{l}\text { Comportamentos não listados acima, sem } \\
\text { interesse para o estudo. }\end{array}$ & $x$ & $x$ & $X$ \\
\hline
\end{tabular}

Durante as fases de maternidade e creche, o grupo misto e o grupo aversivo receberam o mesmo tratamento (aversivo) e, desta forma, os comportamentos analisados foram agrupados. Sendo assim, na fase de maternidade e creche, temos dois tratamentos: aversivo (TA - misto e aversivo) e controle (TC), como descrito anteriormente. Durante a maternidade, foi realizado um dia de observação, no pré-desmame. Na fase de creche, 
temos quatro observações: o dia do desmame, o dia após o desmame, o segundo dia após o desmame e o último dia de creche, antes de os animais serem transferidos para a sala de crescimento/terminação.

Os comportamentos observados durante a fase de crescimento/terminação foram compostos pelos dias da mudança de ambiente para salas de crescimento e os dois dias subsequentes à mudança. A partir desse período, os animais que receberam tratamento misto começaram a receber o tratamento semelhante ao grupo controle, sendo esta fase composta por três tratamentos: aversivo (TA), misto (TM) e controle (TC).

\subsection{RESULTADOS}

\subsubsection{Desempenho}

Mortalidade na fase de maternidade

Durante a maternidade, ocorreram duas mortes entre os animais que receberam o tratamento controle: uma por esmagamento e uma por hipoglicemia ou inanição, somando $3,12 \%$ de mortalidade. Ambas as mortes ocorreram antes de os animais começarem a receber o tratamento. Entre os animais que sofreram o tratamento aversivo ocorreram sete mortes por esmagamento, cinco mortes por hipoglicemia ou inanição e três mortes por outros fatores, somando $11,28 \%$ de mortalidade. Destas mortalidades, seis mortes por esmagamento, uma morte por hipoglicemia e duas mortes por outros fatores ocorreram após o início da aplicação do tratamento aversivo.

Peso

Os pesos não difeririam entre os tratamentos para nenhuma fase $(P>0,05)$. A média dos pesos e seus erros padrão estão dispostos na Tabela 3. 
Tabela 3 - Médias e erros padrão dos pesos $(\mathrm{kg})$ dos leitões que sofreram os tratamentos controle, misto ou aversivo, nas diferentes fases: ao nascimento, ao desmame, início da fase de crescimento, início da fase de terminação e dia pré-abate.

\begin{tabular}{lccc}
\hline \multicolumn{1}{c}{ Tratamento } & Controle & Misto & Aversivo \\
\hline Nascimento & $2,22 \pm 0,04$ & $1,71 \pm 0,03$ & $1,98 \pm 0,04$ \\
Desmame & $8,5 \pm 0,14$ & $7,71 \pm 0,16$ & $8,22 \pm 0,15$ \\
Crescimento & $30,2 \pm 0,49$ & $27,12 \pm 0,55$ & $29,74 \pm 0,48$ \\
Terminação & $68,44 \pm 0,83$ & $64,03 \pm 0,78$ & $70,25 \pm 0,85$ \\
Pré-abate & $104,15 \pm 1,51$ & $97,29 \pm 1,21$ & $101,84 \pm 1,41$ \\
\hline
\end{tabular}

Para todos os valores: $\mathrm{P}>0,05$.

Ganho de peso diário e conversão alimentar

Para avaliar o ganho de peso diário (GPD) e a conversão alimentar (CA), os animais foram divididos em tratamento e sexo para melhor visualização dessas variáveis. Houve interação tripla entre tratamento, sexo e fase de criação. As médias do GPD estão dispostas na Tabela 4 e as médias de CA estão dispostas na Tabela 5.

Tabela 4 - Ganho de peso diário (Kg) dos leitões conforme o tratamento, sexo e fase de criação.

\begin{tabular}{lccc|ccc}
\hline \multicolumn{1}{c}{ Sexo } & \multicolumn{3}{c|}{ Macho } & \multicolumn{3}{c}{ Fêmea } \\
\cline { 2 - 7 } Fase/Tratamento & Controle & Misto & Aversivo & Controle & Misto & Aversivo \\
\hline Creche & $0,512 \mathrm{a}$ & $0,463 \mathrm{a}$ & $0,516 \mathrm{a}$ & $0,523 \mathrm{a}$ & $0,462 \mathrm{a}$ & $0,508 \mathrm{a}$ \\
Crescimento & $0,862 \mathrm{~b}$ & $0,830 \mathrm{~b}$ & $0,954 \mathrm{a}$ & $0,834 \mathrm{~b}$ & $0,811 \mathrm{~b}$ & $0,842 \mathrm{~b}$ \\
Terminação & $1,170 \mathrm{a}$ & $1,056 \mathrm{~b}$ & $1,006 \mathrm{~b}$ & $0,848 \mathrm{c}$ & $0,844 \mathrm{c}$ & $0,791 \mathrm{c}$ \\
\hline
\end{tabular}

Letras diferentes na mesma linha diferem estatisticamente entre si $(P<0,05)$.

Tabela 5 - Conversão alimentar dos leitões conforme o tratamento, sexo e fase de criação.

\begin{tabular}{lccc|ccc}
\hline \multicolumn{1}{c}{ Sexo } & \multicolumn{3}{c|}{ Macho } & \multicolumn{3}{c}{ Fêmea } \\
\cline { 2 - 7 } Fase/Tratamento & Controle & Misto & Aversivo & Controle & Misto & Aversivo \\
\hline Creche & $1,73 \mathrm{a}$ & $1,82 \mathrm{a}$ & $1,70 \mathrm{a}$ & $1,77 \mathrm{a}$ & $1,84 \mathrm{a}$ & $1,73 \mathrm{a}$ \\
Crescimento & $2,71 \mathrm{a}$ & $2,66 \mathrm{a}$ & $2,61 \mathrm{~b}$ & $2,66 \mathrm{a}$ & $2,71 \mathrm{a}$ & $2,93 \mathrm{a}$ \\
Terminação & $3,17 \mathrm{e}$ & $3,55 \mathrm{~d}$ & $3,81 \mathrm{~d}$ & $3,98 \mathrm{c}$ & $4,41 \mathrm{~b}$ & $4,73 \mathrm{a}$ \\
\hline
\end{tabular}

Letras diferentes na mesma linha diferem estatisticamente entre si $(P<0,05)$. 


\subsubsection{Observação dos comportamentos dos animais}

\section{Maternidade}

A fase de maternidade contou com um dia de observação. Nesta observação, realizada no dia anterior ao desmame, foi notada maior frequência do comportamento "no comedouro", "no bebedouro", "interação agonística", "brincando" e "no escamoteador", em leitões TA, em comparação com leitões do TC. Nesta fase, leitões do TC passaram mais tempo "repousando" e "fuçando/explorando" do que leitões TA (Tabela 6).

Tabela 6 - Comportamentos observados durante a fase de maternidade e as respectivas médias das frequências relativas e erro padrão (\%), dentro dos dois tratamentos: controle e aversivo.

\begin{tabular}{lccr}
\hline \multicolumn{1}{c}{ Comportamentos Observados } & Controle & Aversivo & \multicolumn{1}{c}{ P } \\
\hline Comportamento de amamentação & $18,90 \pm 1,06$ & $19,39 \pm 0,77$ & 0,08 \\
No comedouro & $2,28 \pm 0,23$ & $3,49 \pm 0,17$ & $<0,001^{*}$ \\
No bebedouro & $0,42 \pm 0,09$ & $0,66 \pm 0,07$ & $0,01^{*}$ \\
Interação agonística & $0,57 \pm 0,14$ & $0,97 \pm 0,10$ & $0,01^{*}$ \\
Interagindo com a mãe & $3,19 \pm 0,25$ & $2,50 \pm 0,19$ & 0,26 \\
Interação positiva com os irmãos & $3,85 \pm 0,27$ & $3,56 \pm 0,20$ & 0,73 \\
Brincando & $0,92 \pm 0,21$ & $1,48 \pm 0,16$ & $0,01^{*}$ \\
Fuçando/Explorando & $9,92 \pm 0,50$ & $8,27 \pm 0,37$ & $0,03^{*}$ \\
Repousando & $28,20 \pm 1,13$ & $24,20 \pm 0,83$ & $0,006^{*}$ \\
No escamoteador & $30,52 \pm 1,98$ & $34,73 \pm 0,71$ & $0,0004^{*}$ \\
Outros & $1,23 \pm 0,21$ & Zero & 0,16 \\
\hline
\end{tabular}

$* \mathrm{P}<0,05$.

\section{Creche}

Na fase de creche houve quatro observações: o dia do desmame, o dia após o desmame (dia 2), o segundo dia após o desmame (dia 3) e o último dia de creche. A frequência dos comportamentos está exposta na Figura 10. Houve interação entre tratamento e dia para os comportamentos "interação agonística" $(P=0,04)$, "belly-nosing" $(P=0,001)$, "fuçando/explorando" $(P=0,0007)$ e "repouso" $(P=0,03)$. Leitões TA apresentaram maior frequência de comportamentos indicativos de estresse como "interação agonística" e "belly-nosing. "Interação agonística" teve maior frequência em leitões TA no dia do desmame, no dia 2 e no dia 3, sendo sua frequência reduzida no último dia de creche. Já o comportamento "belly-nosing" teve maior frequência em leitões TA no dia 2 e no dia 3, e teve baixa apresentação no dia do desmame e no último dia de creche. Leitões TA também 
apresentaram maior frequência do comportamento "repouso" no dia do desmame, no dia 2 e no dia 3. Os animais TC demonstraram maior frequência do comportamento "fuçando/ explorando" nos três primeiros dias de creche, em comparação com animais TA.

Os comportamentos "no comedouro" e "tentativa de fuga" demonstraram efeito de data $(P<0,0001)$, mas não apresentaram efeito de tratamento $(P=0,6$ e $P=0,4$, respectivamente). O comportamento "no comedouro" foi mais frequente no dia 3 do que no dia 2 e no dia do desmame e mais frequente no último dia de creche do que nos demais dias, nos dois tratamentos. O comportamento "tentativa de fuga" foi mais frequente no dia do desmame, diminuiu pela metade no dia 2 e foi inexistente no dia 3 e no último dia de creche.

Foi observado efeito de tratamento $(P=0,006)$, mas não de dia $(P=0,09)$, para o comportamento "brincando", onde os animais que receberam o tratamento controle tiveram maior frequência do comportamento no dia do desmame. Apesar de não ter se mostrado um comportamento frequente, ele foi inexistente nas observações em quase todos os dias para os leitões TA.

O comportamento "no bebedouro" não demonstrou efeito de dia, nem de tratamento e nem interação entre data e tratamento $(1,78 \pm 0,98 \%$ para TC e $1,49 \pm 0,96 \%$ para $T A, P=0,31)$.

\section{Crescimento / terminação}

Os comportamentos observados durante a fase de crescimento/terminação são compostos do dia da mudança de ambiente para salas de crescimento (dia 1) e os dois dias subsequentes à mudança (dia 2 e dia 3). A frequência dos comportamentos observados está disposta na Figura 11.

Nos três primeiros dias do crescimento houve interação entre tratamento e dia para os comportamentos "no comedouro" $(P=0,04)$, "tentativa de fuga" $(P=0,0006)$, "fuçando/ explorando" $(P<0,001)$, "na lâmina d'água" $(P=0,001)$ e "repouso" $(P<0,001)$, onde os animais do TA tiveram maior frequência dos comportamentos "no comedouro", "tentativa de fuga" e "fuçando/ explorando". O comportamento "na lâmina d'água" foi mais frequente em animais do TA e do TM do que em animais do TC. O TC teve maior frequência do comportamento "repouso". 
a) No comedouro

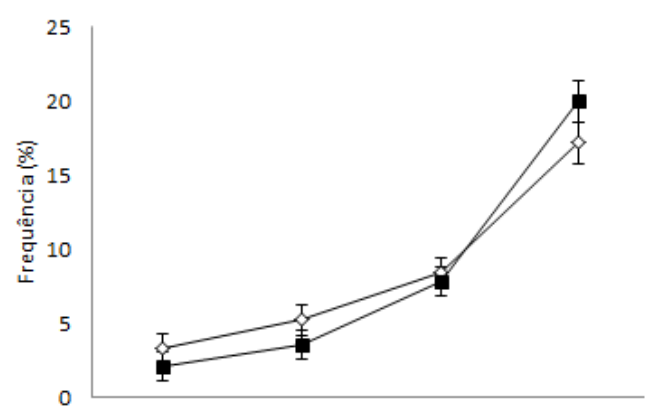

c) Interações agonísticas

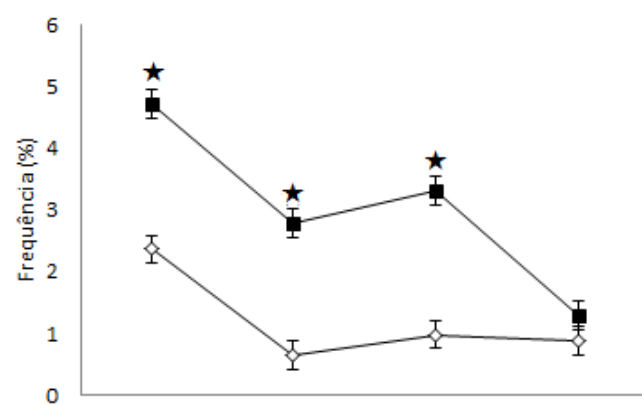

e) Belly-nosing

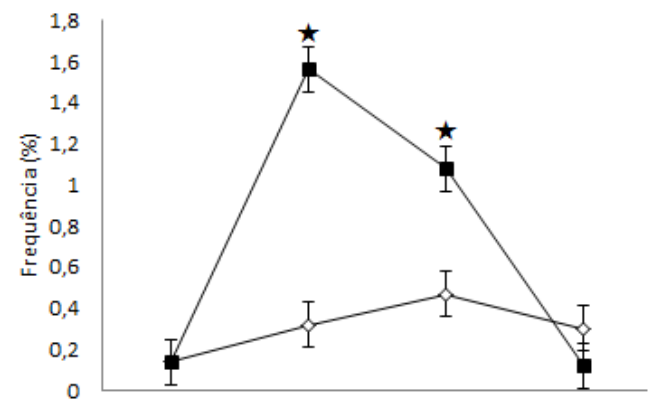

g) Fuçando/Explorando

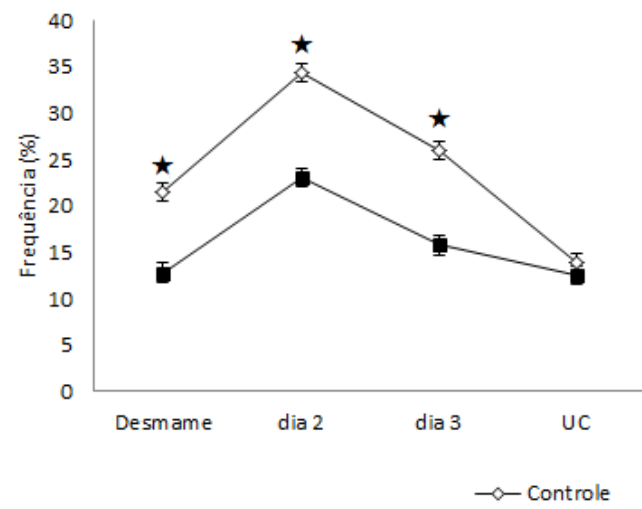

b) No bebedouro

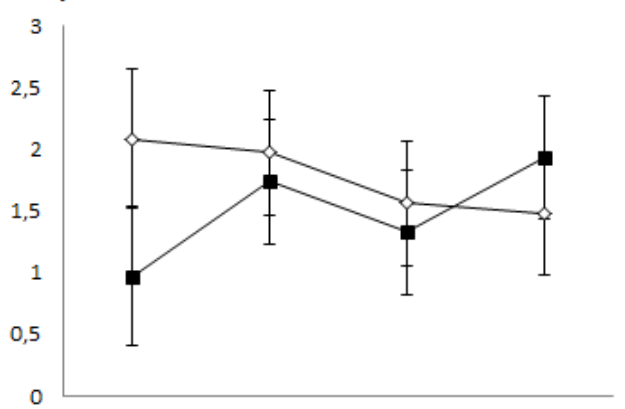

d) Tentativa de fuga

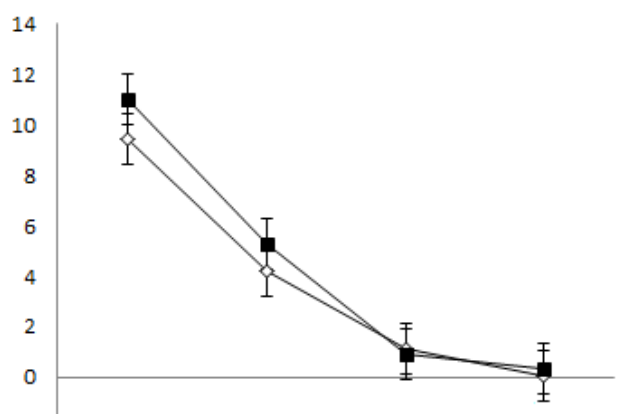

f) Brincando

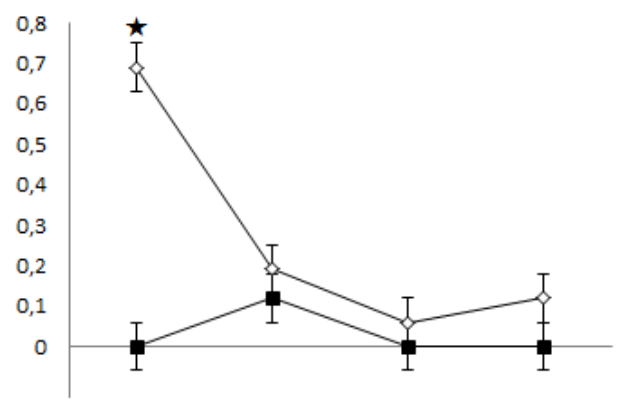

h) Repouso

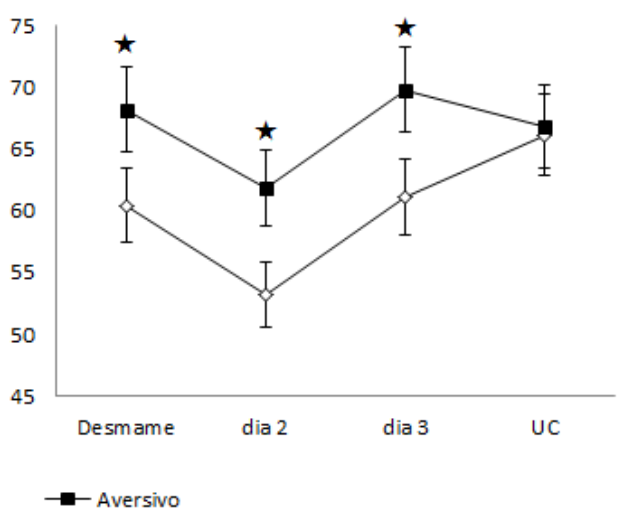

Figura 10 - Frequência relativa (média \pm erro padrão \%) dos comportamentos a) no comedouro, b) no bebedouro, c) interação agonística, d) tentativa de fuga e) belly-nosing, f) brincando, g) fuçando/ explorando, h) repouso; observados durante a fase de creche nos leitões tratados de forma aversiva (marcador escuro) e controle (marcador claro). $\star: \mathrm{P}<0,05$ entre os tratamentos, no mesmo dia. UC: último dia de creche. 
a) No comedouro

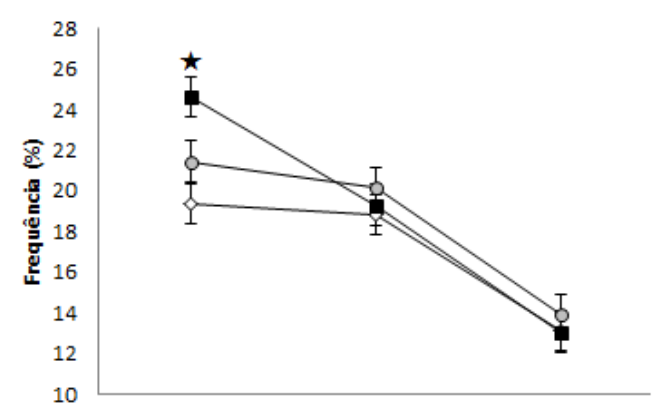

c) Interação agonística

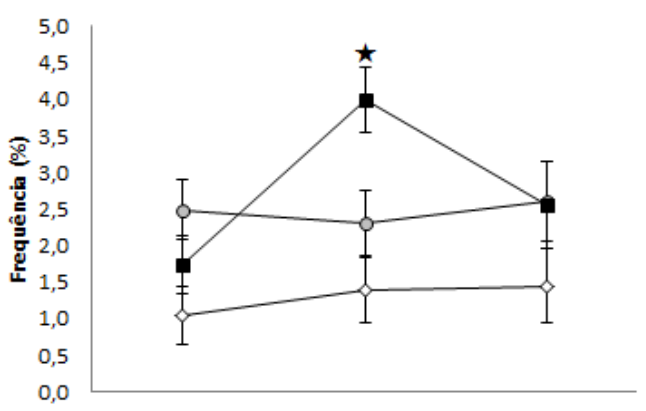

e) Brincando

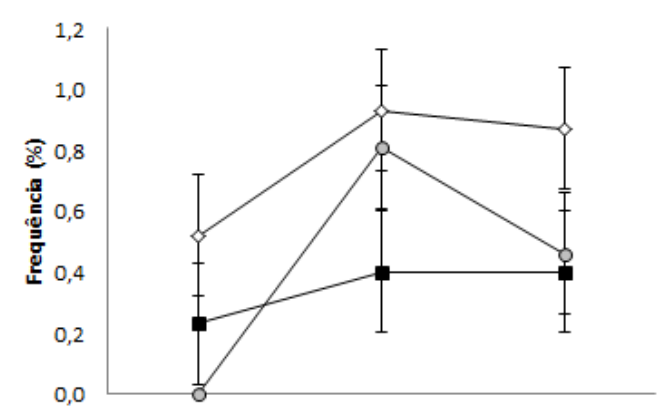

g) Na lâmina d'água

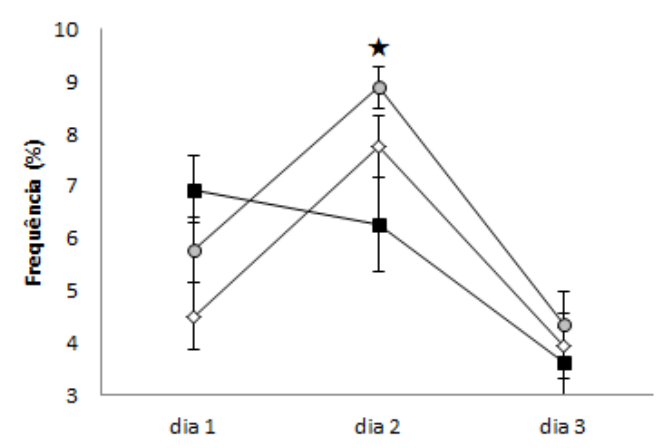

b) No bebedouro

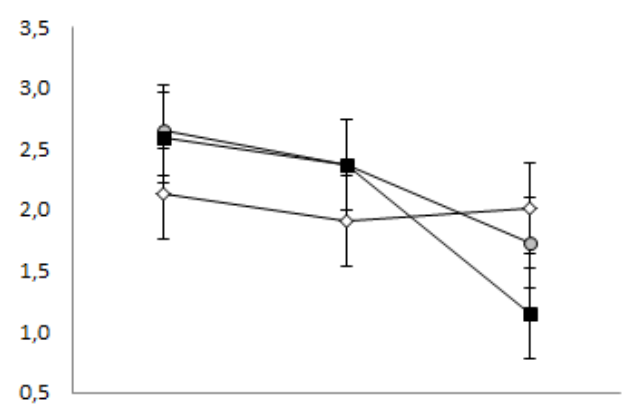

d) Tentativa de fuga

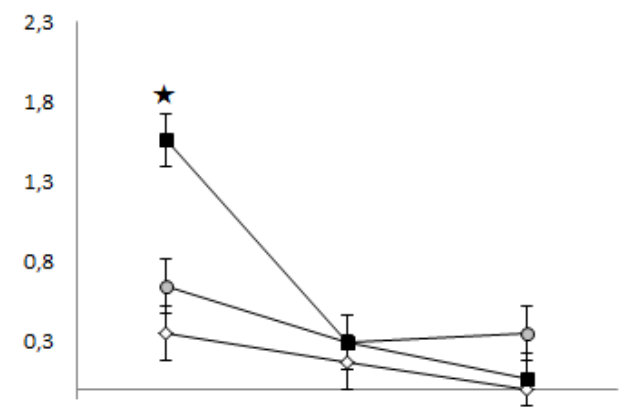

f) Fuçando / Explorando

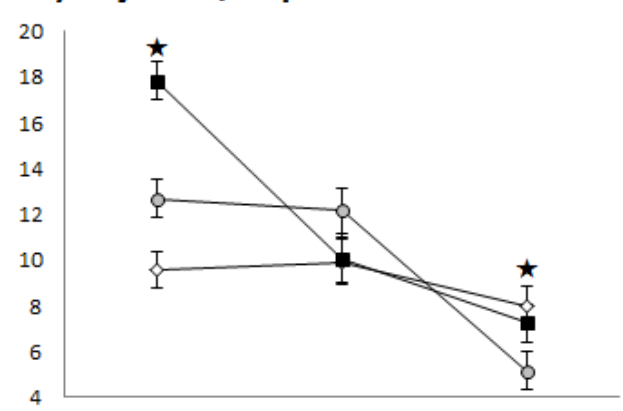

h) Repouso

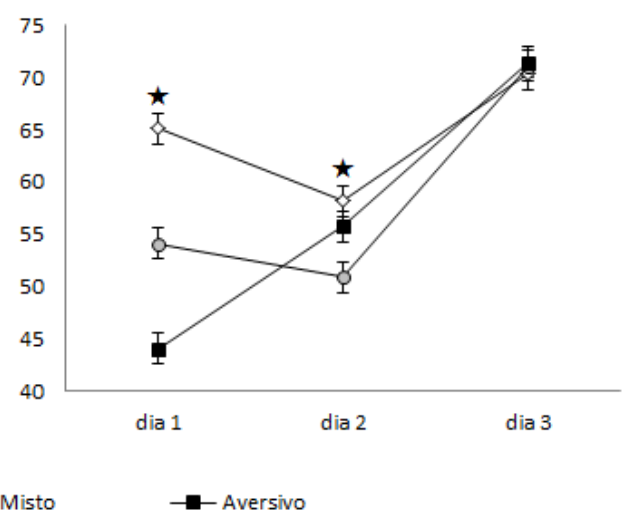

Figura 11- Frequência relativa (média \pm erro padrão \%) dos comportamentos a) no comedouro, b) no bebedouro, c) interação agonística, d) tentativa de fuga e) brincando, f) fuçando/explorando, g) na lâmina d'água, h) repouso; observados durante os três primeiros dias da fase de crescimento nos leitões tratados de forma aversiva (marcador escuro), controle (marcador claro) e misto (marcador cinza). $\star: P<0,05$ entre tratamentos, no mesmo dia. 
Os leitões do TA passaram mais tempo "no comedouro" e "tentativa de fuga" que os demais animais no dia 1, mas esta diferença não se manteve em outros dias. Com o passar dos dias, a frequência desses comportamentos diminuiu em todos os animais. Os animais do TA demonstraram maior frequência de "fuçando/explorando" que os demais no dia 1, enquanto TC apresentou a menor frequência. No dia 2, todos os animais mostraram a mesma frequência de comportamentos exploratórios. No dia 3, os animais do TC e do TA apresentaram maior frequência deste comportamento. Com o passar dos dias, este comportamento foi demonstrando menor frequência pelos leitões em TA e em TM, mas se manteve igual em TC.

Os animais em TA e em TM passaram mais tempo na lâmina d'água no dia 1. No dia 2, apenas os leitões TM passaram mais tempo na lâmina d'água. No dia 3, todos os animais demonstraram a mesma frequência deste comportamento. Os leitões em TA demonstraram uma queda na frequência de "na lâmina d'água", enquanto os animais em TM e em TC demonstraram maior frequência deste comportamento no dia 2 do que no dia 1 e dia 3.

Os leitões do TC apresentaram maior frequência de "repouso" no dia 1, mas no dia 3 todos tiveram a mesma frequência deste comportamento. No dia 2, TC e TA demonstraram maior frequência de repouso do que leitões em TM. Para todos os animais, o comportamento de repouso aumentou em frequência com o decorrer dos dias.

O comportamento "interação agonística" foi influenciado pelo tratamento $(P=0,0002)$, onde os leitões em TC demonstraram menor frequência do que os animais em TM e em TA (TC = 1,29 $\pm 0,26 \% ; \mathrm{TM}=2,47 \pm 0,26 \%$; TA = 2,76 $\pm 0,26 \%)$. Os comportamentos "no bebedouro", "belly-nosing" e "brincando" não demonstraram efeito de tratamento $(P=0,69 ; 0,18 ; 0,07$, respectivamente) e nem efeito de dia $(P=0,17 ; 0,38 ; 0,058$, respectivamente).

\subsection{DISCUSSÃO}

Como esperado, os leitões tratados de forma aversiva demonstram maior frequência de comportamentos indicativos de estresse, como "interação agonística", "belly-nosing" e "tentativa de fuga", e baixa frequência de comportamentos exploratórios comuns à espécie. 
O desmame precoce é um dos eventos mais estressantes para os leitões. Outros estudos encontraram uma resposta comportamental indicativa de estresse em leitões desmamados precocemente (WEARY; APPLEBY; FRASER, 1999; HÖTZEL et al., 2010), mas o tratamento aversivo imposto aos animais durante a fase de maternidade parece estar associado as maiores frequências destes comportamentos. Além disso, o padrão de interações agonísticas e tentativa de fuga se mantiveram na fase de creche e de crescimento/terminação, mesmo não havendo mistura de leitegada. Neste caso, parece que a qualidade do tratamento recebido pelos animais influenciou diretamente o padrão comportamental dos mesmos.

\section{Maternidade}

No último dia de maternidade os leitões despenderam a maior parte do seu tempo em "comportamento de amamentação", "repousando" e "dentro do escamoteador" (onde, normalmente, os animais estão repousando). Os leitões em TC passaram mais tempo repousando fora do escamoteador, contrastando com os leitões em TA que passaram mais tempo dentro do escamoteador. As salas dos dois tratamentos eram semelhantes em relação à incidência de sol e ventilação natural, e os escamoteadores tinham a mesma fonte de aquecimento. Leitões em TA tiveram maior incidência de esmagamento e, portanto, talvez se sentissem mais seguros dentro do escamoteador, sem contato com a mãe. Além disso, é possível que o escamoteador tenha representado uma proteção ao tratamento aversivo.

Mortalidade por esmagamento ou inanição pode ser consequência da baixa ingestão de leite. Leitões mais magros tendem a passar mais tempo perto dos tetos da porca e, por sua localização, são mais susceptíveis a serem esmagados (WEARY; LAWSON; THOMPSON, 1996). Quando os leitões são esmagados, eles vocalizam (se possível) e a fatalidade deste esmagamento depende da resposta da mãe a este pedido de socorro (VIEUILLE et al., 2003). $\mathrm{O}$ índice de mortalidade mais elevado entre os leitões tratados de forma aversiva durante a fase de maternidade pode ter ocorrido pela baixa resposta das porcas estressadas ao pedido de socorro dos filhotes esmagados.

Morte por inanição ou hipoglicemia pode ocorrer porque a porca não produziu suficiente colostro ou leite, ou porque os leitões não consumiram leite em quantidade 
suficiente (KIRKDEN; BROOM; ANDERSEN, 2014). O estresse que a porca sofreu, juntamente com os leitões, pode ter ajudado na diminuição da produção de leite e consequente inanição de seus filhotes, visto que porcas que sofrem outros tipos de estresse têm a produção de leite comprometida (estresse causado por doenças: JACKSON; COCKROFT, 2007; estresse causado por calor: FRASER, 1970; estresse por barulho ambiental: ALGERS; JENSEN, 1991). Por outro lado, leitões pequenos podem não ter sucesso no estabelecimento da ordem da teta e, assim, ficarem sem teto na hora da amamentação (FRASER, 1990).

Os animais em TA foram mais ativos que animais em TC e têm maior frequência de comportamentos indicativos de estresse, como interação agonística. TA passou mais tempo no comedouro, mas não ganhou mais peso em comparação com TC. Isso indica que provavelmente, estes animais estavam manipulando o alimento, mas não o estavam ingerindo. Visto que o estresse pode contribuir para o surgimento de comportamentos anormais (HEMSWORTH; COLEMAN, 1998), os animais que estavam manipulando o alimento, sem o ingerir, podem ser comparados a animais que demonstram comportamentos anômalos como mordedura de barra da cela parideira realizada por porcas com fome ou caudofagia realizado por leitões que sofrem de monotonia ambiental (BROOM; FRASER, 2007). Já o comportamento "brincando" elevado em TA durante a maternidade seria benéfico e natural se não fosse observado somado a outros comportamentos de alto gasto de energia, pois, desta forma, evidencia a inquietação dos animais frente ao ambiente desconfortavelmente estressante em decorrência do tratamento recebido.

Por outro lado, animais em TC apresentaram maior frequência de comportamentos exploratórios, como fuçar e explorar o ambiente. Este comportamento é natural de leitões com quatro semanas de idade, fora do cativeiro, que estariam começando sua vida social e aprendendo a fuçar vendo a mãe realizando este comportamento (NEWBERRY et al., 1998). Provavelmente, animais em TC estavam mais seguros para explorar o ambiente que habitavam.

\section{Creche}

Para a formação do grupo após o desmame, foram escolhidos aleatoriamente três leitões da mesma leitegada e este grupo se manteve até o abate, não havendo mistura de leitegadas em nenhuma fase. Mesmo assim, animais em TA apresentaram maior frequência 
de interações agonísticas nos três primeiros dias pós-desmame, e o mesmo aconteceu na fase de crescimento. Este achado corrobora outros estudos, onde leitões desmamados foram alojados em novas salas, sem mistura de leitegada (MASON; JARVIS; LAWRENCE, 2003; JARVIS et al., 2008). Este aumento na agressividade pode ser atribuído ao reestabelecimento da nova hierarquia social necessária na ausência da mãe (JARVIS et al., 2008). Neste caso, os dois tratamentos deveriam ter apresentado alta frequência de interações agonísticas. Suínos são animais gregários que estabelecem uma hierarquia normalmente estável e linear (JENSEN; WOOD-GUSH, 1984), por reconhecer facilmente seus parceiros de grupo (MCLEMAN et al., 2008). Estes animais tendem a ser agressivos com animais que não são familiares, mas não costumam demonstrar comportamento agressivo direcionado a animais conhecidos (HELD; COOPER; MENDL, 2009). Estresse nos primeiros dias de vida dos leitões pode influenciar negativamente o reconhecimento social destes animais (SOUZA; ZANELLA, 2008; HÖTZEL et al. 2011). Sendo assim, o tratamento aversivo sofrido desde os primeiros dias de vida pode ter causado um distúrbio no reconhecimento social destes animais, fazendo com que eles demonstrem maior frequência de interação agonística até o final de suas vidas.

Leitões em TA também apresentaram maior frequência de belly-nosing, comportamento anômalo onde o leitão direciona sua motivação por mamar sugando a região abdominal do seu parceiro de baia (FRASER; BROOM, 1990). Quando o animal é separado repentinamente da mãe e do leite, a sua fonte até então exclusiva de alimento, ele se frustra com a impossibilidade de mamar e direciona esta frustração a seus colegas de baia. Este tipo de comportamento é comumente observado em pós-desmames abruptos e precoces (FRASER; BROOM, 1990) e era esperado ocorrer tanto com animais em TA quanto com aqueles em TC que foram desmamados aos 28 dias de idade. Hötzel et al., 2011 sugere que a associação de fatores estressantes durante o desmame pode prejudicar a resposta do animal a este evento. Os animais em TA que apresentam maior frequência deste comportamento anômalo podem ter reagido negativamente ao desmame de forma mais severa, pela associação do tratamento aversivo aos eventos estressantes do desmame.

Animais tratados de forma aversiva tiveram maior frequência do comportamento "repouso". Provavelmente estes animais despendiam tanta energia com interação 
agonística, tentativa de fuga e belly-nosing, que precisavam de mais tempo de repouso para repor suas energias.

Por outro lado, leitões em TC estiveram mais tempo explorando e fuçando o novo ambiente, comportamento que eles demonstraram mais frequentemente desde a fase de maternidade. Além disso, TC apresentou maior frequência de "brincando". Comportamentos exploratórios e lúdicos são esperados em leitões desta idade (NEWBERRY et al., 1988) e parecem reportar a maior segurança de leitões TC para explorar o ambiente que habitavam e, assim, terem liberdade de realizar os comportamentos naturais para esta fase de vida. Somando comportamentos como "fuçando/explorando", "brincando" e "repouso", tem-se mais de $80 \%$ dos comportamentos realizados pelos animais em TC nos primeiros dias de creche, frequência de comportamento considerada normal para a idade dos animais (O'CONNELL, 2009), demonstrando que leitões em TC mantém o padrão comportamental normal para a fase, retratando seu melhor bem-estar.

O comportamento "tentativa de fuga" foi observado em maior frequência no primeiro dia, teve sua frequência reduzida na metade no segundo dia, sendo quase inexistente no terceiro e no último dia de creche, independente do tratamento recebido pelos animais. Em alguns estudos, este comportamento foi observado com maior frequência nos animais que sofreram maior estresse ao desmame, como por exemplo, desmame precoce (HÖTZEL et al., 2010) e tratamento aversivo durante a fase de maternidade (SOMMAVILLA; HÖTZEL; DALLA COSTA, 2011). No presente estudo não houve diferença de resposta dos animais em TC e em TA para este comportamento específico. Se este fosse o único comportamento indicativo de estresse observado, seria possível especular que não houve diferença comportamental entre TA e TC; no entanto, o padrão comportamental referenciando um maior estresse nos animais TA sugere que o comportamento "tentativa de fuga" observado nos animais TA indica apenas maior inquietação.

Com relação ao último dia de creche, os animais em TA e em TC despenderam mais de $80 \%$ de seus tempos realizando os comportamentos "repouso" e "no comedouro". Os animais estavam com 70 dias de vida nesta observação. Em ambiente natural, leitões desta idade estão praticamente desmamados e começam a busca por alimento sólido (NEWBERRY; WOOD-GUSH, 1988). Com os leitões crescendo rapidamente, o consumo de alimento tende a aumentar. Como o ambiente de creche era estéril, sem enriquecimento ambiental, é 
normal que os animais observados tendam a dormir mais, provável fruto da falta de motivação em realizar outros comportamentos.

\section{Crescimento/terminação}

$\mathrm{Na}$ fase de crescimento e terminação, os animais em TM pararam de receber o tratamento aversivo e começaram a receber um tratamento igual ao TC (controle/neutro). Sendo assim, têm-se três tratamentos durante a fase de crescimento/terminação: tratamento aversivo (TA), tratamento controle (TC) e tratamento misto (TM).

Durante os três primeiros dias de crescimento, os animais em TC mantiveram o padrão comportamental do último dia de creche: mais de $80 \%$ da frequência dos comportamentos demonstrados eram "repouso" e "no comedouro". Este padrão é o esperado para animais com 70 dias de vida, em ambiente natural (NEWBERRY; WOODGUSH, 1988).

Os grupos de animais não foram modificados. Mesmo assim, leitões em TA e em TM demonstraram o dobro de interação agonística do que leitões em TC. É possível que o estresse sofrido nas primeiras fases de vida dos leitões tratados de forma aversiva (TM recebia tratamento aversivo nas fases de maternidade e creche), tenha causado um impacto irreversível na capacidade de reconhecimento social dos animais (SOUZA; ZANELLA, 2008).

No dia da mudança de ambiente para a sala de crescimento, os leitões em TA demonstraram o comportamento "tentativa de fuga", enquanto animais em TM e em TC apresentaram frequências insignificantes deste comportamento em todos os dias de crescimento. Além disso, leitões em TA apresentaram maior frequência de "fuçando/explorando" e "no comedouro". Mais uma vez, animais em TA demonstraram um padrão comportamental de alto gasto de energia.

Mesmo que o GPD e a conversão alimentar tenham se mostrado melhores no começo do crescimento/terminação para machos tratados de forma aversiva, esta vantagem não se manteve até o dia pré-abate, quando machos que receberam o tratamento controle tiveram melhores resultados de GPD e conversão alimentar. Isso sugere que as visitas ao 
comedouro realizado pelos animais TA no início do crescimento/terminação não refletiam maior consumo de alimento.

Na fase de terminação, os machos de todos os tratamentos ganharam mais peso por dia do que as fêmeas, independente do tratamento recebido. Isto pode ter acontecido porque os machos foram imunocastrados e, portanto, tiveram o crescimento semelhante a machos inteiros, maior do que o crescimento de fêmeas (WEILER et al., 2013). Os machos que receberam tratamento controle tiveram maior GPD e menor conversão alimentar em relação aos demais animais. Mesmo assim, o melhor desempenho na fase de terminação não foi suficiente para que o peso vivo final dos animais diferisse. A influência do tratamento no ganho de peso de suínos é contraditória: assim como alguns pesquisadores encontraram correlação negativa entre o tratamento aversivo e o ganho de peso dos animais (HEMSWORTH; BARNETT; HANSEN, 1981, 1987; GONYOU; HEMSWORTH; BARNET, 1986; HEMSWORTH; VERGE; COLEMAN, 1996), outros pesquisadores não conseguiram detectar nenhuma diferença de desempenho entre animais tratados de forma aversiva ou neutra/ racional (HEMSWORTH; BARNETT, 1991; SOMMAVILLA; HÖTZEL; DALLA COSTA, 2011), corroborando os achados deste trabalho.

\subsection{CONCLUSÃO}

Leitões tratados de forma aversiva demonstram um padrão comportamental de alto gasto energético, indicando o elevado estresse sofrido por esses animais (e o pobre bemestar), independente de o tratamento ter durado toda a vida ou apenas as fases de maternidade e creche. Mesmo não havendo diferença de desempenho, esses resultados indicam um empobrecimento do bem-estar desses animais. Aqueles tratados de forma aversiva são mais responsivos à mudança de ambiente, demorando mais dias para adaptarse ao novo ambiente. Após o término do tratamento aversivo, os animais do tratamento misto mantiveram o mesmo padrão comportamental indicativo de estresse que os animais tratados de forma aversiva durante toda a vida, indicando um efeito residual do tratamento recebido nas primeiras etapas da vida. Por sua vez, animais que receberam tratamento controle expressaram mais comportamentos naturais, retratando seu melhor nível de bemestar. 


\section{EFEITO DA QUALIDADE DO TRATAMENTO NO MEDO DE SUÍNOS}

O medo é um estado emocional consequente à percepção de um perigo iminente (BOISSY, 1995) e está ligado a estímulos físicos ou psíquicos que podem empobrecer o bemestar do animal, acarretando uma série de respostas comportamentais e fisiológicas (HEMSWORTH; COLEMAN, 1998).

A resposta que um animal tem ao se deparar com um humano traz informações sobre a qualidade da relação que há entre ambos (HEMSWORTH; COLEMAN, 1998), sendo que $o$ ato de evitar esta pessoa pode caracterizar o medo sentido pelo animal (BROOM; FRASER, 2007). Alguns estudos sugerem que suínos conseguem distinguir pessoas diferentes (TANIDA et al., 1995; KOBA; TANIDA, 2001) e, dessa forma, evitar a pessoa da qual ele tenha medo. Não se sabe ao certo quais as pistas que os suínos usam para distinguir pessoas, mas parece estar mais relacionado à postura do que a própria face do humano (KOBA; TANIDA, 2001). Por outro lado, há estudos que afirmam que os animais não têm a capacidade de distinguir entre pessoas diferentes, respondendo a todos os humanos de forma semelhante (HEMSWORTH; BARNETT; HANSEN, 1981; HEMSWORTH; COLEMAN; COX, 1994; HEMSWORTH; BARNETT; CAMPBELL, 1996). Nesse caso, a presença de um tratador que cause medo aos animais pode pôr em risco o sucesso do manejo da granja.

Alguns testes podem ser utilizados para aferir medo em suínos e estão, muitas vezes, relacionados com a capacidade de reconhecimento de outros animais e de humanos, como o Teste de Aproximação Humana. Outros testes estão relacionados com o isolamento social e o uso da novidade, como é o caso do Teste de Área Desconhecida e Novo Objeto (MURPHY; NORDQUIST; VAN DER STAAY, 2014).

Este estudo foi realizado com o objetivo de determinar se leitões podem discriminar e recordar os seus tratadores habituais. Além disso, teve por objetivo comparar a resposta dos animais tratados de forma aversiva ou controle quando submetidos ao isolamento social e teste de novidade ambiental. Esperava-se que os animais tratados de forma aversiva mantivessem maior distância de seu tratador habitual e que recordassem essa pessoa. 
Esperava-se, também, que estes animais respondessem de forma mais severa ao estresse do isolamento e novidade ambiental, impostos pelos testes de medo.

\subsection{METODOLOGIA}

Os testes comportamentais foram realizados para aferir medo nos suínos e para observar seu padrão comportamental frente a diferentes situações. O Teste de Aproximação Humana foi realizado para verificar se os animais reconheciam seu tratador habitual e se eles se recordavam desta pessoa após um breve período sem contato com a mesma.

\subsubsection{Teste de Aproximação Humana}

Este teste foi realizado duas vezes: 1) uma semana após o desmame (animais com 35 dias de vida); 2) uma semana após a mudança de ambiente da creche para a sala de crescimento/terminação (animais com 91 dias de vida).

No primeiro teste (35 dias), os animais foram testados em relação ao seu tratador habitual e uma pessoa desconhecida aos animais, também do sexo feminino. 0 tratador habitual estava vestido com sua roupa habitual (macacão de cor laranja e botas pretas) e a pessoa desconhecida trajava roupas e botas brancas.

No segundo teste (91 dias), os animais foram testados em relação ao seu tratador habitual e uma pessoa desconhecida aos animais, também do sexo feminino. Neste teste, os leitões do tratamento misto foram testados em relação a três pessoas: o tratador aversivo da maternidade e creche (com quem eles não tinham contato desde os 70 dias de vida, o qual vestia macacão laranja e botas pretas), com o tratador habitual controle (o qual tratou os animais desde o 70 dia de vida até o abate, que trajava macacão azul e botas pretas), e uma pessoa desconhecida (roupa de cor branca e bota branca). As pessoas testadas participaram desta etapa de forma aleatória e separadamente.

Para este teste, um leitão de cada baia foi escolhido ao acaso para participar ( $n=16$ animais por tratamento), e os animais selecionados participaram em ordem aleatória. 0 teste consistiu em colocar cada leitão, separadamente, na extremidade de uma área de teste 
de $2 \mathrm{~m}$ de comprimento e $80 \mathrm{~cm}$ de largura (Figura 12a). Na outra extremidade, a pessoa teste estava posicionada e após 2 minutos de habituação dos animais, a pessoa caminhava lentamente, com os braços junto ao corpo em direção ao leitão e sempre de forma silenciosa. A resposta do animal a esta aproximação humana foi classificada em escores:

1) Leitão permitia ser tocado pela pessoa teste (Figura 12b);

2) A pessoa conseguia se aproximar menos que $0,5 \mathrm{~m}$, mas o leitão se movia antes de ser tocado pela pessoa teste;

3) Leitão se movimentava quando a pessoa chegava a 0,5 m de distância do mesmo;

4) Leitão tentava fugir quando a pessoa estava há mais de 0,5 m de distância (Figura 12c).

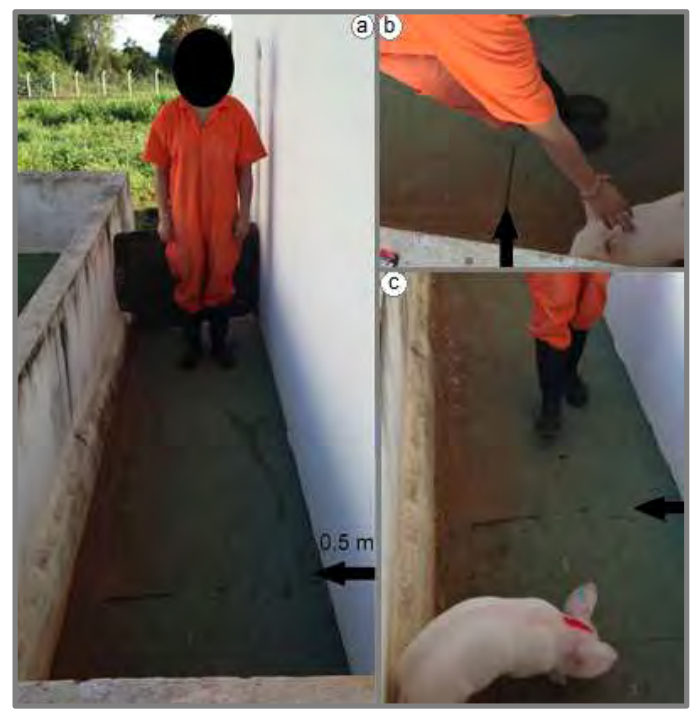

Figura 12 - Área do Teste de Aproximação Humana com o tratador habitual esperando o leitão a ser testado (a), escore 1 (b) e escore 4 (c). Seta está demonstrando a linha de 0,5 m marcada no chão da área de teste.

\subsubsection{Testes de medo em suínos}

Tanto para o Teste de Área Desconhecida quanto para o Teste do Objeto Novo, os animais foram filmados e os comportamentos foram observados posteriormente. As vocalizações foram observadas em tempo real, sendo anotados os eventos de vocalização no período observado. Os comportamentos foram observados em instantâneos a cada 5 segundos, totalizando 60 observações por animal por repetição no Teste de Área 
Desconhecida e 36 observações por animal por repetição para o Teste do Objeto Novo. Os testes (adaptado de FORKMAN et al., 2007) foram repetidos após 2 dias. Os comportamentos foram divididos em "ativo" (animal em atividade) e "inativo" (animal parado, não realizando nenhuma atividade aparente), caracterizando o comportamento ativo como "defecando", "urinando", "tentativa de fuga", "interação com o objeto" e "atenção com o objeto", sendo estes dois últimos comportamentos exclusivos do Teste do Objeto Novo.

\subsubsection{1. $\quad$ Teste de Área Desconhecida}

O comportamento dos leitões quando colocados numa área desconhecida a eles foi observado neste teste, que ocorreu na terceira semana após o desmame, quando os animais estavam com 46 dias de idade. Para isso, um leitão de cada baia, que não tinha sido utilizado no Teste de Aproximação Humana ( $n=16$ animais/tratamento), foi levado por uma pessoa desconhecida até a área teste, individualmente, ficando neste local por 5 minutos. $A$ área de teste era uma baia desconhecida aos animais, e nela eles não tinham contato visual com outros animais (Figura 13).

\subsubsection{Teste do Objeto Novo}

Após a conclusão do Teste de Área Desconhecida foi realizado o Teste do Objeto Novo, onde um balde roxo era introduzido no centro da área de testes e ao animal era permitido interagir com esse objeto por até 3 minutos (Figura 13).

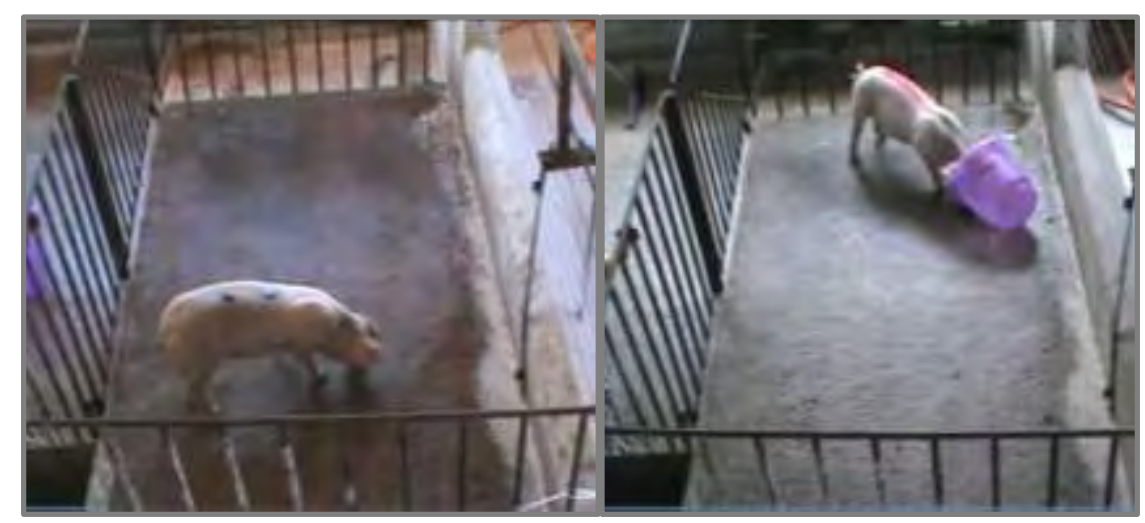

Figura 13 - Animal durante o Teste de Área Desconhecida realizando o comportamento ativo/ explorando (esquerda) e durante o Teste do Objeto Novo, interagindo com o objeto (direita). 


\subsection{RESULTADOS}

\subsubsection{Teste de Aproximação Humana}

As médias dos escores apresentados, juntamente com os erros padrão, estão dispostas na Figura 14. No dia 35 e no dia 91, os animais que receberam tratamento controle (TC) não demonstraram diferença na média dos escores apresentados para o tratador habitual (controle) e desconhecido $(\mathrm{P}=0,48)$. Os animais tratados de forma aversiva (TA) demonstraram diferença entre os escores apresentados para o tratador habitual (aversivo) e a pessoa desconhecida nos dois dias de teste $(P=0,02)$. Os animais que receberam tratamento misto (TM) mostraram diferença entre os tratadores aos 35 dias, quando foram testados para o tratador habitual aversivo e para a pessoa desconhecida $(P<0,001)$. Já aos 91 dias, quando foram testados com três pessoas, os animais do tratamento misto apresentaram maior média de escore com relação ao antigo tratador habitual aversivo $(P<0,001)$ em comparação à pessoa desconhecida e o tratador habitual controle.
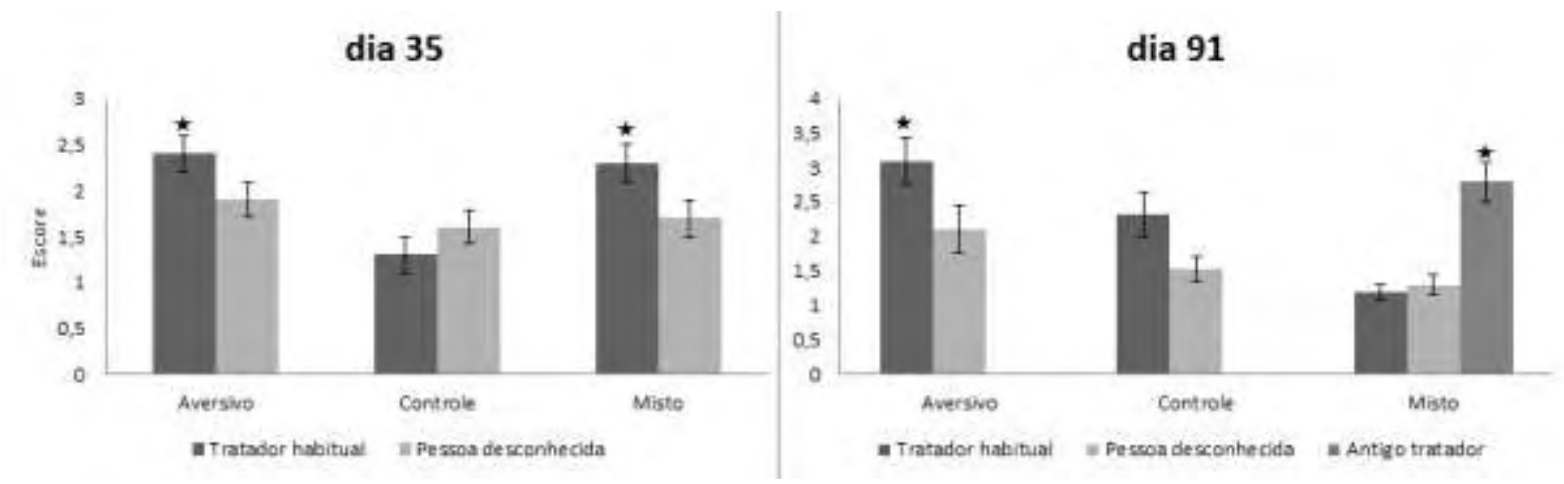

Figura 14 - Médias de escores e erros padrão (\%) apresentadas nos dias 35 e 91 por leitões tratados de forma aversiva, mista e controle. Escore 1: leitão permitia ser tocado pela pessoa teste; escore 2: a pessoa conseguia se aproximar menos que $0,5 \mathrm{~m}$, mas o leitão se movia antes de ser tocado pela pessoa teste; escore 3: leitão se movimentava quando a pessoa chegava a $0,5 \mathrm{~m}$ de distância do mesmo. Leitão tentava fugir quando a pessoa estava há mais de $0,5 \mathrm{~m}$ de distância. $\star P<0,05$. 


\subsubsection{Testes de medo em suínos}

Para ambos os testes os tratamentos misto e aversivo foram agrupados, pois recebiam o mesmo tratamento (aversivo) durante o período de teste. Sendo assim, houve dois tratamentos para o Teste de medo em suínos: aversivo (TA) e controle (TC). Os testes foram repetidos após dois dias de intervalo, sendo assim dois dias de observação (D1 e D2).

\subsubsection{Teste de Área Desconhecida}

Não houve interação entre tratamento*dia*minuto, nem interação entre tratamento*minuto. Houve interação tratamento*dia para os comportamentos "ativo" e "inativo" $(P=0,01)$, onde os escores do D2 para os dois tratamentos diferiram do D1 e os tratamentos diferiram entre si no D2 (Figura 15).

\section{Teste de Área Desconhecida}

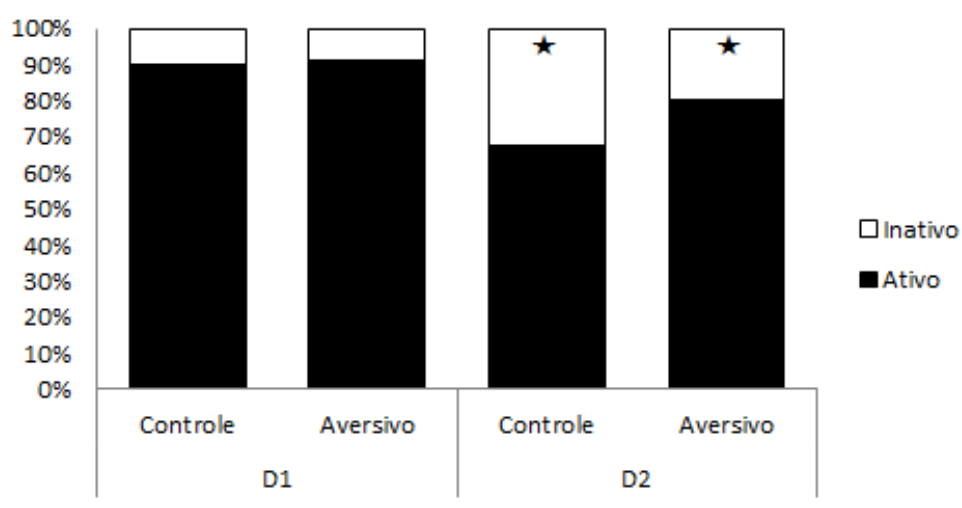

Figura 15: Média e erro padrão das frequências relativas das interações tratamento*dia dos comportamentos ativo e inativo, para os tratamentos controle e aversivo, no primeiro dia de observação (D1) e no segundo dia de observação (D2). $\star$ : $P<0,05$, para dia e tratamento.

Houve efeito de dia para o comportamento "defecando", onde os animais defecaram com mais frequência no segundo dia de observação do que no primeiro ( $D 1=3,18 \pm 0,6 \%$; D2 $=6,76 \pm 0,6 \% ; P<0,0001)$. O comportamento "urinando" não apresentou nenhum efeito significativo (tratamento: $\mathrm{P}=0,6$; dia: $\mathrm{P}=0,3$; minuto: $\mathrm{P}=0,6$ ). 
As vocalizações apresentaram diferença entre minutos, com aumento gradual, conforme demonstrado na Figura 16.

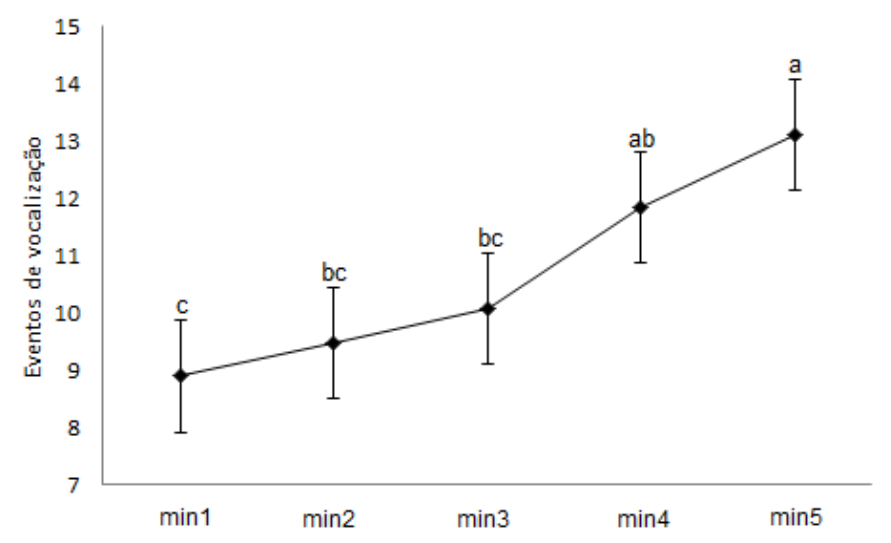

Figura 16: Eventos de vocalização durante os 5 minutos do Teste de Área Desconhecida.

\subsubsection{Teste do Objeto Novo}

As interações entre tratamento*dia e tratamento*minuto estão dispostas na Tabela 7. Não houve interação tripla entre tratamento*dia*minuto para nenhum comportamento. Os comportamentos "inativo" e "ativo" apresentam uma tendência de interação entre tratamento*dia (Figura 17). Dentro do comportamento "ativo", o comportamento "defecando" apresentou interação entre tratamento*dia (Figura 17).

Tabela 7 - Valores de P para as interações entre tratamento e dia, tratamento e minuto, para os comportamentos ativo, inativo, defecando e atenção para o objeto.

\begin{tabular}{lcc}
\hline & Tratamento*Dia & Tratamento*Minuto \\
\hline Atenção com o objeto & n.s. & 0,01 \\
Inativo/Ativo & 0,06 & n.s. \\
Defecando & 0,005 & n.s. \\
Urinando & n.s. & n.s. \\
Tentativa de fuga & n.s. & n.s. \\
Interação com o objeto & n.s. & n.s. \\
\hline
\end{tabular}

n.s.: $P>0,10$ 


\section{Teste do Objeto Novo}

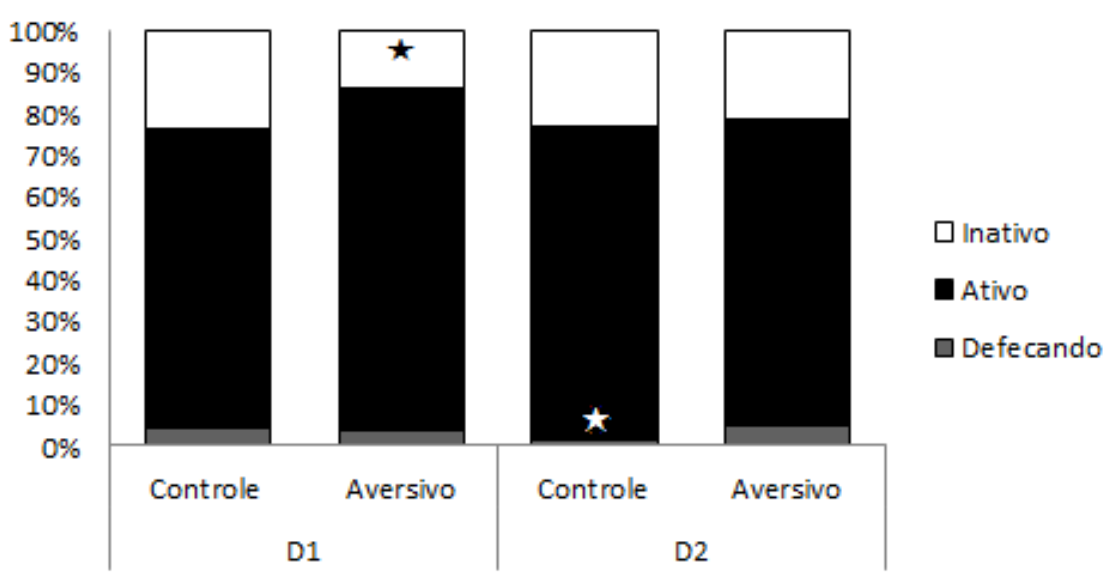

Figura 17: Média e erro padrão das frequências relativas das interações tratamento*dia dos comportamentos: a) ativo, b) inativo, c) defecando; para os tratamentos controle (marcador claro) e aversivo (marcador escuro), nos primeiro dia de observação (D1) e no segundo dia de observação (D2). $\star$ : $P<0,05$, para o comportamento ativo / inativo, para dia e tratamento. $\mathrm{P}<0,05$, para 0 comportamento defecando, para dia e tratamento.

Dentro do comportamento "ativo", o comportamento "atenção com o objeto" apresentou interação entre tratamento*minuto (Figura 18), onde este comportamento foi mais frequente no minuto 1 e para o tratamento aversivo.

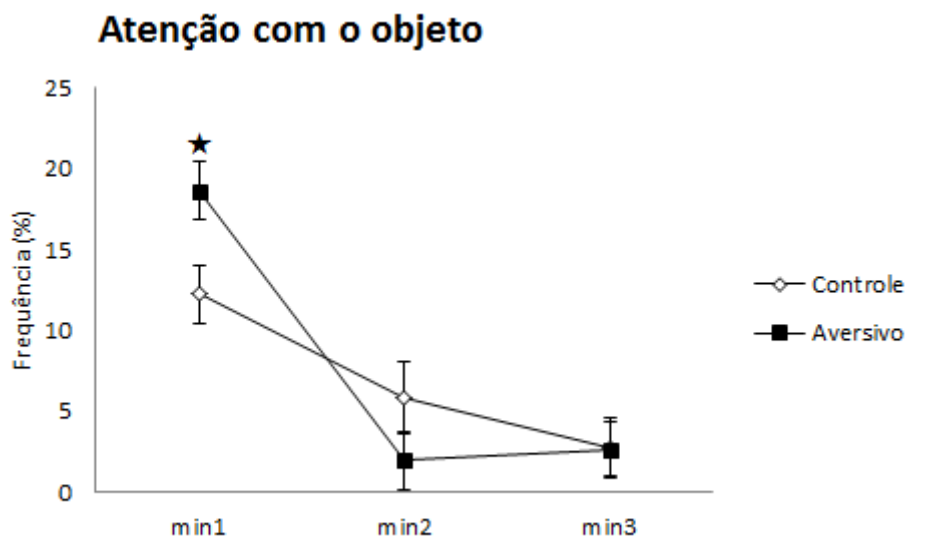

Figura 18: Média e erro padrão das frequências relativas da interação tratamento*minuto do comportamento "atenção com o objeto", para os tratamentos controle (marcador claro) e aversivo (marcador escuro), nos três minutos observados. $\star$ : $\mathrm{P}<0,05$, entre tratamento. 
O comportamento "tentativa de fuga" apresentou efeito de dia sendo mais frequente no primeiro dia ( $D 1=9,73 \pm 1,03 \%$; $D 2=3,64 \pm 1,03 \%$; $P<0,0001$ ). Já o comportamento "urinando" não demonstrou nenhum efeito significativo (tratamento: $P=0,8$; dia: $P=0,1$; minuto: $P=0,2)$.

Os leitões controle demoraram menos tempo para fazer o primeiro contato com o objeto desconhecido ( $T C=0: 50 \pm 0: 10 \mathrm{~min} ; \mathrm{TA}=1: 25 \pm 0: 05 \mathrm{~min} ; \mathrm{P}=0,03$ ) e passaram mais tempo em contato com o mesmo ( $T C=14,91 \pm 2,06 \%$; $T A=9,72 \pm 1,41 \% ; P=0,005$ ).

As vocalizações foram mais frequentes no tratamento controle do que no aversivo ( $T C=16,95 \pm 1,29 ; T A=13,89 \pm 0,88 ; P=0,05$ ). Os leitões vocalizaram mais no primeiro dia do que no segundo ( $D 1=17,93 \pm 1,1 ; D 2=12,91 \pm 1,1 ; P=0,001$ ).

\subsection{DISCUSSÃO}

Teste de Aproximação Humana

Os achados para o dia 35 e o dia 91 com relação a animais que receberam o tratamento aversivo e o tratamento controle corroboram estudos preliminares (HÖTZEL et al., 2007; SOMMAVILLA; HÖTZEL; DALLA COSTA, 2011), onde leitões tratados de forma aversiva evitaram seu tratador habitual, mas não evitaram uma pessoa desconhecida, e leitões tratados de forma neutra não evitaram seu tratador habitual, nem uma pessoa desconhecida. A resposta dos animais que receberam tratamento misto, testados aos 35 dias de idade, foi igual à resposta dos animais tratados de forma aversiva, o que era esperado já que os dois grupos recebiam tratamento (aversivo) idêntico nesta fase. Com relação ao teste realizado no dia 91, animais que receberam o tratamento misto evidenciam não generalizar a resposta para as três pessoas testadas, evitando apenas o antigo tratador habitual (aversivo), reforçando os resultados mostrados por Sommavilla et al., 2011. Estes resultados sugerem que suínos podem reconhecer um tratador aversivo habitual e lembrarse de um antigo tratador, mesmo depois de semanas sem contato com essa pessoa.

Evitar uma pessoa aversiva sem generalização dessa resposta a pessoas desconhecidas indica que leitões conseguem discriminar uma pessoa de acordo com suas experiências vividas. Trabalhos anteriores sugerem que suínos podem reconhecer 
coespecíficos (MENDL et al., 2001; MCLEHMAN et al., 2008) e humanos (TANIDA et al., 1995; KOBA; TANIDA, 1999; TANIDA; NAGANO, 1998; KOBA; TANIDA, 2001; BRAJON et al., 2015). Koba e Tanida (2001) concluíram que as pistas que parecem ser utilizadas para que suínos distingam humanos estão ligadas à visão, como cor de roupa utilizada e estrutura corporal; para estes autores, pistas olfativas e pistas auditivas são menos importantes. Isto parece responder quais pistas os leitões usaram para distinguir entre as pessoas testadas no presente experimento, visto que eram mulheres de diferentes estaturas corporais e vestiam roupas de cores diferentes, mas durante os testes, permaneciam em silêncio. Tanida e colaboradores (1991) concluíram que estes animais conseguem distinguir a cor azul de outras cores, mas não conseguem distinguir entre a cor verde e vermelha, por exemplo. Desta forma, é possível supor que a cor da roupa usada pelas pessoas testadas pode ter sido uma pista utilizada pelos animais para distinguir entre os tratadores, além da estatura corporal.

Por outro lado, a resposta que os animais tratados de forma aversiva tiveram ao serem testados com o tratador aversivo pode caracterizar um reflexo condicionado negativo à presença do tratador e não o reconhecimento da pessoa em si (KELLER, 1973). Neste caso, o estímulo eliciador (reforço) seria o tratamento aversivo, a resposta eliciada seria o medo que o animal sentia e o estímulo condicionante poderia ser a cor laranja vestida pela pessoa aversiva, ou até mesmo, a própria pessoa. Talvez este condicionamento atrelado ao tratamento aversivo não tenha se extinguido em apenas três semanas em que o leitão não recebeu o reforço negativo. Caso a cor laranja tenha sido o estímulo eliciador, e não a pessoa em si, não é possível afirmar que os leitões TM reconheceram a pessoa aversiva, mas sim, que eles estavam condicionados e evitar a cor laranja.

\section{Testes de Medo - Área Desconhecida e Objeto Novo}

No primeiro dia dos testes, durante o Teste de Área Desconhecida, o comportamento dos animais frente à novidade de uma área desconhecida, somada à novidade do isolamento social pode ser observado. Nesta ocasião, todos os animais se mostraram mais ativos. Uma alta frequência de atividade nos primeiros 5 minutos de teste pode ser relacionada com alto nível de ansiedade (GOULD; DAO; KOVACSICS, 2009). Na 
segunda visita ao local de teste, a área não era mais novidade e, então, esperava-se que os animais ficassem menos ativos e menos ansiosos, como o encontrado por outros pesquisadores que realizaram o Teste de Área Desconhecida (DONALD et al., 2011; KANITZ et al., 2009). Isso foi de fato observado nos leitões em TC, que no segundo dia estavam menos ativos do que animais em TA. Nos dois dias de teste os animais apresentaram maior frequência de tentativa de fuga e vocalizações durante os últimos minutos de teste. $O$ esperado era que os animais diminuíssem a frequência de vocalização e a tentativa de fuga na medida em que o ambiente fosse ficando conhecido, corroborando os achados de Kanitz et al. (2009).

A frequência de vocalizações está mais relacionada com a resposta ao isolamento social, enquanto que a frequência de atividade está mais relacionada com a resposta à novidade ambiental (MURPHY; NORDQUIST; VAN DER STAAY, 2014). Os animais testados vocalizaram frequentemente nos dois dias, mas apenas nos leitões em TA a frequência de atividade aumentou no segundo dia. Mendl (1999) propôs que o estresse de algumas criações de animais pode afetar diretamente a capacidade de aprendizado e memória dos animais, devido às altas concentrações de glicocorticoides no cérebro. Talvez, a alta frequência de atividade demonstrada pelos animais em TA no segundo dia fosse uma resposta ao estresse do tratamento, que influenciou o centro de memória e fez com que os animais se esquecessem de que eles conheciam a área de teste.

No Teste do Objeto Novo, leitões em TC entraram em contato com o objeto mais rapidamente e mantiveram este contato por mais tempo. Os suínos são motivados a explorar, não apenas para procurar alimentos (SPINKA, 2009), mas também pela simples necessidade de explorar (MURPHY; NORDQUIST; VAN DER STAAY, 2014), e preferem interagir com objetos desconhecidos (WOOD-GUSH e VESTERGAARD, 1991). Em contraste, os leitões TA apresentaram menor frequência de contato com o objeto, mas ficaram mais tempo direcionando sua atenção para o mesmo. Este comportamento de imobilização frente a uma novidade está altamente relacionado com a ansiedade sofrida pelos animais (MURPHY; NORDQUIST; VAN DER STAAY, 2014). 


\subsection{CONCLUSÃO}

Leitões de 91 dias de idade parecem reconhecer e recordar um antigo tratador habitual e associá-lo com a qualidade do tratamento recebido. Isso acontece mesmo quando ocorre uma mudança na qualidade do tratamento por um período de até três semanas. Além disso, estes animais parecem não generalizar a resposta de evitação de um tratador aversivo para uma pessoa desconhecida, pois independentemente da qualidade do tratamento recebido anteriormente, não permitem que as pessoas se aproximem deles de forma semelhante. Este trabalho também mostra que leitões tratados de forma aversiva são mais ativos nos testes de medo e mais atentos a um objeto novo, sem aumentar a frequência de contato com o mesmo, sugerindo que são animais mais ansiosos e medrosos do que animais que receberam o tratamento controle. Ou seja, conclui-se que leitões tratados de forma aversiva são mais medrosos à novidade, ao isolamento social e ao tratador aversivo. 


\section{EFEITO DO ENRIQUECIMENTO AMBIENTAL NA FASE DE TERMINAÇÃO E DA QUALIDADE DO TRATAMENTO RECEBIDO NO COMPORTAMENTO E DESEMPENHO DE SUÍNOS}

No Brasil, a criação convencional de suínos confinados acontece geralmente em ambientes sem enriquecimento ambiental. Suínos em vida natural dispendem grande parte de seu tempo realizando comportamentos exploratórios, como fuçar e explorar, em busca de alimentos e para reconhecimento do ambiente que os cerca (STOLBA; WOOD-GUSH, 1989). Confinado, em um ambiente simples, este comportamento típico do suíno não pode ser expresso, resultando em frustração e comportamentos anormais (BROOM; FRASER, 2007). Muitas vezes os animais redirecionam a motivação por fuçar para contemporâneos de baia, o que, por sua vez, pode culminar em interações agonísticas (BEATTIE; WALKER; SNEDDON, 1995).

O enriquecimento ambiental pode ser introduzido na criação de suínos confinados e ser eficaz em diminuir a incidência desses problemas. É necessário estudar as necessidades de cada espécie para que esta prática seja efetiva. A simples introdução de objetos na baia dos animais não caracteriza um bom enriquecimento ambiental. O objeto ideal para enriquecimento ambiental de leitões deveria possuir as seguintes características: ser complexo, mutável, destruível, manipulável e conter partes comestíveis (STUDNITZ; JENSEN; PEDERSEN, 2006). A frequência de belly-nosing, por exemplo, pode ser diminuída em ambientes enriquecidos com objetos que instiguem os leitões a fuçar o material (BENCH; GONYOU, 2006). As brigas por comida e para estabelecer hierarquia podem ser diminuídas com a presença do enriquecimento ambiental (O'CONNELL; BEATTIE, 1999).

Como visto anteriormente nas outras seções deste trabalho, animais que receberam tratamento aversivo apresentaram maior frequência de comportamentos anormais, hiperatividade e ansiedade e, consequentemente, maior frequência de interações agonísticas. A implementação de enriquecimento ambiental pode distrair o animal, diminuindo o comportamento oral dirigido a outros animais da baia, acarretando na diminuição das interações agonísticas e comportamentos anormais (BROOM; FRASER, 2007). Desta forma, parece que o enriquecimento ambiental pode estar relacionado com a qualidade do tratamento e influenciar a resposta comportamental dos suínos. 
O objetivo deste experimento foi averiguar se o enriquecimento ambiental influencia o desempenho dos animais e se esse efeito varia em função do tratamento recebido (controle, misto ou aversivo). Esperava-se que animais que recebessem enriquecimento ambiental tivessem melhor desempenho e que o enriquecimento ambiental diminuísse os comportamentos indicativos de estresse dos animais que receberam um tratamento aversivo.

\subsection{METODOLOGIA}

Durante as fases de crescimento e terminação, os animais receberam três tratamentos: aversivo (TA), controle (TC) e misto (TM). O TM recebeu TA até a mudança de ambiente para crescimento/terminação e começou a receber TC durante a fase de crescimento/terminação. Nas fases crescimento/terminação, metade dos animais de cada tratamento recebeu uma forma de enriquecimento, dado logo após o tratamento da manhã.

Os enriquecimentos eram serragem de madeira com uvas passas distribuída pelo chão (medida de um balde de 20 litros. Figura 19) ou uma abóbora em pedaços por leitão ou uma maçã por leitão ou um brinquedo por leitão feito com cano de PVC com orifícios por onde saiam 20 uvas passas que estavam no interior do brinquedo (Figura 19). Estes enriquecimentos eram oferecidos após os tratamentos do período da manhã (a cada três dias) de forma aleatória para evitar a habituação dos animais. Os animais que receberam o enriquecimento eram sempre os mesmos (mesmas baias) e os animais que não receberam o enriquecimento nunca tiveram contato com o mesmo.

O comportamento dos animais durante o último dia antes do jejum pré-abate foi filmado e analisado posteriormente por duas pessoas treinadas e com as observações calibradas. Foram observados em instantâneos a cada 5 min, durante 12 horas, totalizando 144 observações por animal. Os comportamentos observados e suas definições estão expostos na Tabela 8.

Os animais foram pesados individualmente, no dia da mudança para a sala de crescimento/terminação, no dia em que a ração de crescimento foi trocada para ração de recria (terminação) e no início do dia que antecedeu o abate (antes do jejum pré-abate). 0 consumo de ração da baia foi registrado através da subtração da ração oferecida pela sobra 
e o consumo individual foi calculado a partir da divisão do consumo total pelo número de animais por baia $(n=3)$.

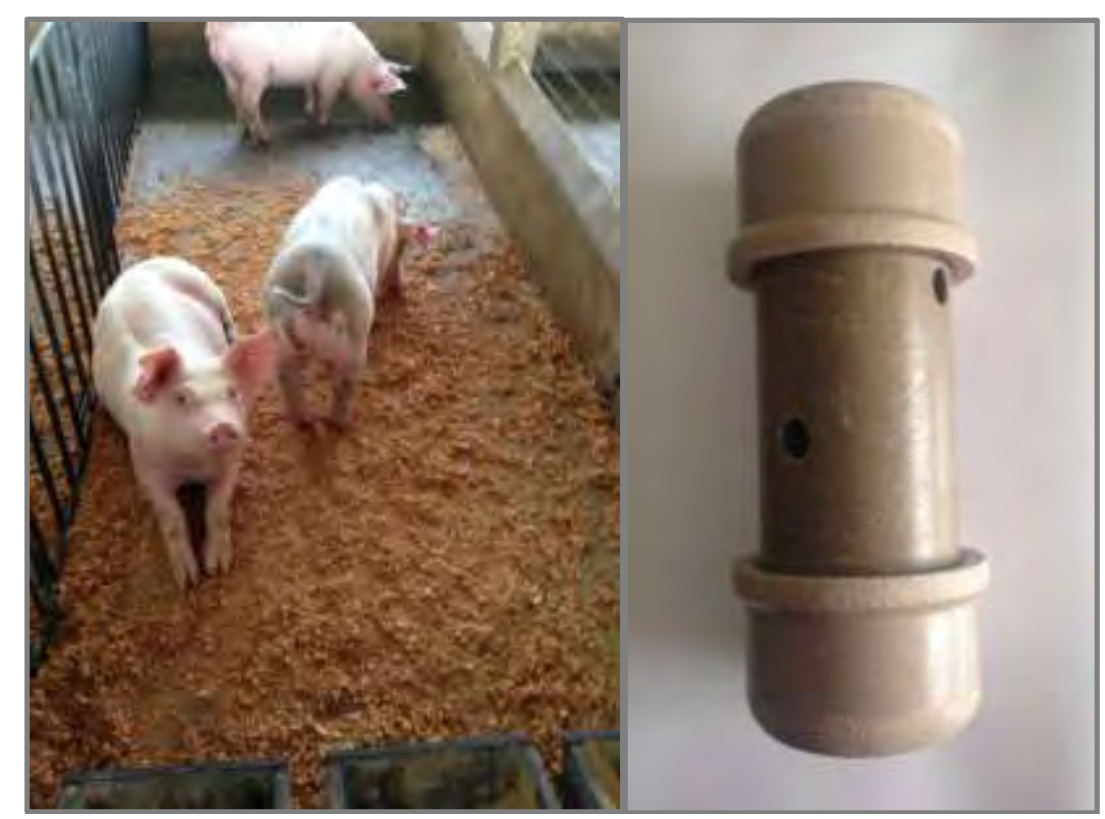

Figura 19 - Esquerda: baia de crescimento/terminação com enriquecimento de serragem e uvas passas; Direita: brinquedo feito com cano de PVC com orifícios por onde saiam as uvas passas que estavam no interior do brinquedo.

Tabela 8 - Etograma de Trabalho: comportamentos observados durante o último dia antes do jejum pré-abate em suínos de terminação e suas definições.

\begin{tabular}{ll}
$\begin{array}{c}\text { Comportamentos } \\
\text { Observados }\end{array}$ & \multicolumn{1}{c}{ Definição dos comportamentos } \\
\hline No comedouro & $\begin{array}{l}\text { Com a cabeça dentro do comedouro, com a boca em contato com a } \\
\text { ração }\end{array}$ \\
\hline No bebedouro & Com a boca em contato com o nipple do bebedouro \\
Interação agonística & $\begin{array}{l}\text { Agredindo ou sendo agredido por outro leitão, mordendo, empurrando } \\
\text { outro animal de forma agressiva ou em retaliação a um ataque } \\
\text { agressivo }\end{array}$ \\
\hline Fuçando/Explorando & $\begin{array}{l}\text { Em atividade exploratória, com o focinho em contato com o chão ou } \\
\text { instalações, ou andando de cabeça baixa, cheirando o chão }\end{array}$ \\
\hline Repousando & $\begin{array}{l}\text { Em pé parado, inativo, deitado ou dormindo, sem realizar nenhuma } \\
\text { atividade }\end{array}$ \\
\hline Na lâmina d'água & Com as quatro patas dentro da lâmina d'água, deitado ou em pé \\
\hline Interação com & Com o nariz ou a boca em contato com o objeto de enriquecimento \\
enriquecimento & Comportamentos não listados acima, sem interesse para o estudo \\
\hline Outros &
\end{tabular}




\subsection{RESULTADOS}

Os comportamentos "no comedouro" $(P=0,04)$ e "repouso" $(P=0,004)$ apresentaram interação entre tratamento e enriquecimento. O comportamento "no comedouro" não diferiu entre os tratamentos TM e TC, independente do tipo de enriquecimento recebido, nem entre esses e o TA sem enriquecimento. Animais TA com enriquecimento apresentaram menor frequência do comportamento (Tabela 9). O comportamento "repouso" foi mais frequente nos animais de TA com enriquecimento, contrastando com os de TA sem enriquecimento que foram os que apresentaram a menor frequência deste comportamento.

Tabela 9 - Frequência (média \pm erro padrão\%) dos comportamentos "no comedouro" e "repouso" observados durante o último dia de terminação (pré-abate), nos tratamentos controle, misto e aversivo.

\begin{tabular}{lcccc}
\hline Comportamento & Tratamento & Controle & Misto & Aversivo \\
\hline No comedouro & CE & $16,09 \pm 2,27 \mathrm{aA}$ & $18,68 \pm 2,11 \mathrm{aA}$ & $11,92 \pm 1,92 \mathrm{bB}$ \\
& SE & $17,59 \pm 1,83 \mathrm{aA}$ & $17,48 \pm 1,43 \mathrm{aA}$ & $17,24 \pm 1,05 \mathrm{aA}$ \\
\hline Repouso & CE & $59,61 \pm 2,73 \mathrm{aA}$ & $62,62 \pm 3,94 \mathrm{aAB}$ & $66,09 \pm 5,09 \mathrm{aA}$ \\
& SE & $59,03 \pm 1,55 \mathrm{aAB}$ & $61,11 \pm 2,33 \mathrm{aA}$ & $54,40 \pm 4,82 \mathrm{bB}$ \\
\hline
\end{tabular}

Letras minúsculas diferentes na mesma coluna, dentro do mesmo comportamento, diferem estatisticamente entre si $(P<0,05)$. Letras maiúsculas diferentes na mesma linha diferem estatisticamente entre si $(P<0,05)$.

Os comportamentos "interação agonística" e "interação com o enriquecimento" apresentaram efeito de tratamento $(P=0,02$ e $<0,001$, respectivamente. Tabela 10). Os animais tratados de forma aversiva, independente do enriquecimento recebido, demonstram maior frequência do comportamento "interação agonística". Entre os animais tratados de forma aversiva, houve uma tendência de maior frequência deste comportamento naqueles que não receberam enriquecimento do que os que receberam enriquecimento $(0,69 \pm 0,1$ e $0,23 \pm 0,07$, respectivamente, $P=0,06)$. Já o comportamento “interação com o enriquecimento" foi mais frequente em animais em TC (Figura 20). 
Interação com o enriquecimento

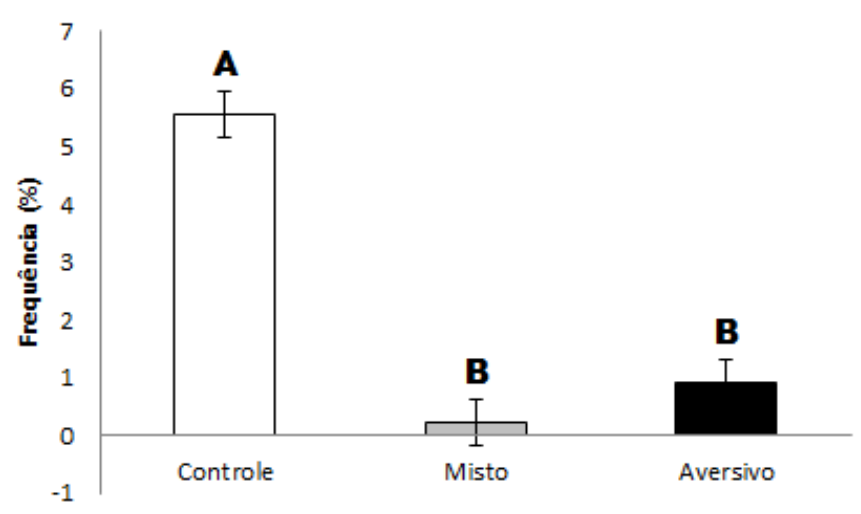

Figura 20 - Frequência relativa (média e erro padrão) do comportamento "interação com o objeto" realizado por animais do tratamento controle, misto e aversivo. Letras diferentes demonstram diferença estatística $(P<0,05)$.

Tabela 10 - Frequência (média \pm erro padrão \%) dos comportamentos "interação agonística", fuçando/ explorando", "na lâmina d'água", observados durante o último dia de terminação (préabate), nos tratamentos controle, misto e aversivo, e com enriquecimento ou sem enriquecimento.

\begin{tabular}{lccc}
\hline Tratamento & $\begin{array}{c}\text { Interação } \\
\text { agonística }\end{array}$ & $\begin{array}{c}\text { Fuçando/ } \\
\text { Explorando }\end{array}$ & $\begin{array}{c}\text { Na lâmina } \\
\text { d'água }\end{array}$ \\
\hline Controle & $0,00 \mathrm{~b}$ & $6,83 \pm 1,37 \mathrm{a}$ & $11,52 \pm 2,05 \mathrm{~b}$ \\
Misto & $0,11 \pm 0,11 \mathrm{~b}$ & $6,83 \pm 1,01 \mathrm{a}$ & $11,05 \pm 1,46 \mathrm{~b}$ \\
Aversivo & $0,46 \pm 0,15 \mathrm{a}$ & $4,63 \pm 0,59 \mathrm{~b}$ & $17,59 \pm 3,40 \mathrm{a}$ \\
Com enriquecimento & $0,07 \pm 0,07 \mathrm{a}$ & $7,18 \pm 1,14 \mathrm{a}$ & $10,07 \pm 1,77 \mathrm{~b}$ \\
Sem enriquecimento & $0,28 \pm 0,11 \mathrm{a}$ & $5,01 \pm 0,66 \mathrm{~b}$ & $16,70 \pm 2,48 \mathrm{a}$ \\
\hline
\end{tabular}

Letras minúsculas diferentes na mesma coluna, dentro do mesmo tratamento (controle, misto e aversivo OU com enriquecimento e sem enriquecimento), diferem estatisticamente entre si $(P<0,05)$.

Houve efeito de tratamento para os comportamentos "fuçando/explorando" $(P=0,01)$ e "na lâmina d'água" ( $P<0,001$, respectivamente) e efeito de enriquecimento ( $P=0,002$ e $<0,001$, respectivamente), mas não houve interações entre tratamento e enriquecimento $(P=0,31$ e $P=0,24$, respectivamente, Tabela 10$)$. Animais em TC e em TM, independente de terem recebido enriquecimento, apresentaram maior frequência de "fuçando/explorando". Animais que receberam enriquecimento ambiental, independente do tratamento, apresentaram maior frequência de "fuçando/explorando". Animais TA, independente de terem recebido enriquecimento, passaram mais tempo na lâmina d'água. O mesmo é observado para animais que não receberam enriquecimento, independente do tratamento recebido. Não houve efeito de interação entre tratamento e enriquecimento, nem efeito de 
tratamento separado de enriquecimento para o comportamento "no bebedouro" $(P=0,96$ e 0,42 , respectivamente).

Com relação ao desempenho dos animais, não houve diferença entre ganho de peso diário, conversão alimentar ou peso final para leitões que receberam ou não enriquecimento, independente do tratamento recebido (Tabela 11).

Tabela 11 - Ganho de peso (Kg), conversão alimentar no crescimento e terminação e peso (kg) no início da terminação e no pré-abate de animais que receberam tratamento controle, misto ou aversivo, com ou sem enriquecimento.

\begin{tabular}{lccccc}
\hline Tratamento & $\begin{array}{c}\text { GPD } \\
\text { Cresc. }\end{array}$ & $\begin{array}{c}\text { C.A. } \\
\text { Cresc. }\end{array}$ & $\begin{array}{c}\text { GPD } \\
\text { Term. }\end{array}$ & $\begin{array}{c}\text { C.A. } \\
\text { Term. }\end{array}$ & $\begin{array}{c}\text { Peso } \\
\text { Abate }\end{array}$ \\
\hline Controle CE & $0,842 \pm 0,013$ & $2,66 \pm 0,05$ & $0,947 \pm 0,048$ & $3,81 \pm 0,18$ & $117,29 \pm 4,07$ \\
Controle SE & $0,857 \pm 0,019$ & $2,71 \pm 0,05$ & $1,099 \pm 0,043$ & $3,26 \pm 0,18$ & $117,45 \pm 3,21$ \\
Misto CE & $0,863 \pm 0,023$ & $2,49 \pm 0,06$ & $0,896 \pm 0,034$ & $3,96 \pm 0,16$ & $120,08 \pm 1,66$ \\
Misto SE & $0,777 \pm 0,013$ & $2,87 \pm 0,06$ & $1,004 \pm 0,034$ & $4,01 \pm 0,21$ & $136,76 \pm 4,92$ \\
Aversivo CE & $0,843 \pm 0,024$ & $2,87 \pm 0,07$ & $0,902 \pm 0,032$ & $4,14 \pm 0,16$ & $127,16 \pm 2,01$ \\
Aversivo SE & $0,957 \pm 0,017$ & $2,66 \pm 0,06$ & $0,903 \pm 0,031$ & $4,36 \pm 0,17$ & $133,65 \pm 2,36$ \\
\hline
\end{tabular}

GPD: ganho de peso diário. C.A.: conversão alimentar. Cresc.: crescimento. Term.: terminação. CE: com enriquecimento. $\mathrm{SE}$ : sem enriquecimento. Para todos os dados $\mathrm{P}>0,05$.

\subsection{DISCUSSÃO}

Dos animais que receberam tratamento aversivo, os que não receberam enriquecimento ambiental apresentaram quase o triplo da frequência de interação agonística e os que receberam enriquecimento não estavam motivados a interagir com o mesmo. Já os animais que receberam o tratamento misto e enriquecimento ambiental diminuíram as interações agonísticas a níveis comparáveis aos animais em TC. Suínos com cinco meses de idade, em ambiente seminatural, tendem a passar $75 \%$ de seu tempo fuçando, explorando atrás de alimentos ou se alimentando (STOLBA; WOOD-GUSH, 1989). Quando confinados em um ambiente sem enriquecimento, os animais muitas vezes direcionam esse comportamento oral a outros animais, o que pode gerar brigas (BEATTIE; WALKER; SNEDDON, 1995).

O enriquecimento ambiental aumentou o comportamento exploratório dos animais. Suínos tendem a explorar mais o ambiente se eles sabem que vão encontrar alguma novidade (HASKELL, 1996) e, como o enriquecimento era modificado a cada oferta, isto pode 
ter incrementado a motivação do animal por realizar comportamentos exploratórios. Os animais em TA tiveram menor frequência de comportamento "fuçando/explorando", o que pode evidenciar um estado de frustração. Animais que vivem sob estresse crônico podem experimentar um estado semelhante à depressão em humanos (desamparo aprendido ou "learned helpless", teoria desenvolvida para humanos por OVERMIER; SELIGMAN, 1967; posteriormente utilizada em animais: HURNIK, 1988; HUNZIKER, 2005; RICHTER et al., 2012) e não se sentirem estimulados a realizar comportamentos exploratórios, por mais que este comportamento the seja natural. Somado a isso, animais que receberam tratamento aversivo, tanto no TM como no TA, apresentaram baixa frequência de contato com o enriquecimento. Animais expostos a estresse podem ter seu estado afetivo prejudicado e isto pode influenciar diretamente seus novos processos cognitivos, deixando-os com uma visão pessimista dos fatos ("cognitive bias", HARDING; PAUL; MENDL, 2004). Talvez estes animais estivessem pessimistas em encontrar novos reforços (alimentos) na exploração do enriquecimento e paravam de fuçá-lo.

A função da lâmina d'água no ambiente é auxiliar os animais a se refrescarem, realizando termólise por condução da água. Leitões procuram água ou lama para banhar seu corpo para perder calor por vias condutiva e evaporativa (D'EATH; TURNER, 2009). Visto que as salas de todos os tratamentos eram ventiladas naturalmente e não havia incidência direta de raios solares dentro das baias, esperava-se que as visitas às lâminas d'água fossem semelhantes entre os tratamentos. Animais que não receberam enriquecimento ambiental passaram quase $7 \%$ a mais de seu tempo na lâmina d'água, sugerindo que para estes animais a lâmina d'água era uma forma de enriquecimento ambiental. Além disso, os leitões em TA também passaram mais tempo dentro da lâmina d'água. Para outras espécies (ratos: LONG et al., 1989; ovelhas: HENRY et al., 2010; humanos: VINKERS et al., 2013; pombos: BITTENCOURT; MELLEU; MARINO-NETO, 2015), o estresse pode aumentar a temperatura corporal dos animais. Assim, considerando que os leitões do TA não pareceram motivados a utilizar os outros enriquecimentos, pode-se especular que eles passavam mais tempo na lâmina d'água em função do desconforto com a temperatura corporal elevada, resultante do estresse devido ao tratamento aversivo.

A similaridade dos comportamentos dos animais tratados de maneira diferente pode ser explicada através de condicionamento respondente, reforço positivo, reforço negativo e 
extinção de condicionamento (KELLER, 1973). Os animais do TM receberam tratamento aversivo até o início da fase de crescimento/terminação e, de alguma forma, foram condicionados de forma respondente ao tratador aversivo, sendo o tratamento aversivo o reforço negativo. Quando pararam de receber o tratamento aversivo, os leitões em TM sem enriquecimento continuaram demonstrando uma frequência de comportamentos semelhante aos animais em TA, sugerindo que mesmo sem receber o reforço negativo, este condicionamento respondente não se extinguiu. Talvez o medo que os animais sentiam de que o reforço negativo pudesse voltar a acontecer, fazia com que esperassem por isso, fomentando o condicionamento. Por outro lado, os animais do TM que receberam enriquecimento, apresentaram frequências de comportamento semelhante a animais em TC, sugerindo que o condicionamento sofrido durante as fases de maternidade e creche havia se extinguido. Talvez o acréscimo do enriquecimento ambiental adicionado ao fim do tratamento aversivo tenha contribuído para a extinção do condicionamento negativo e dado espaço a um novo condicionamento baseado no reforço positivo (enriquecimento). Desta forma, os animais em TM com enriquecimento passaram a se comportar como se nunca tivessem recebido o tratamento aversivo, igualmente aos animais do grupo controle.

\subsection{CONCLUSÃO}

Animais do tratamento misto que receberam enriquecimento, depois de alguns meses sem receber tratamento aversivo, apresentaram um padrão comportamental semelhantemente a animais do tratamento controle. Isso sugere que apenas cessar o tratamento aversivo não seja suficiente para amenizar os efeitos do trauma pós-estresse e do condicionamento animal vinculado à punição do tratamento aversivo. O enriquecimento ambiental pode ser a chave para amenizar este trauma e permitir que os animais tenham seu padrão comportamental normalizado. 


\section{EFEITO DA QUALIDADE DO TRATAMENTO SOBRE A QUALIDADE DA}

\section{CARNE DE SUÍNOS}

O estresse sofrido pelo animal durante a sua vida, ou até mesmo o estresse sofrido poucos instantes antes do abate pode influenciar negativamente a qualidade da carne. Quando o organismo do animal recebe o estímulo estressante, a produção de cortisol é elevada. Uma das funções do cortisol é incitar a transformação de não-açúcares em glicose, aumentando a energia disponível. Para isso, uma das fontes utilizadas é o glicogênio muscular, resultando no aumento da concentração de lactato no sangue (NELSON; COX, 2008). O uso excessivo das reservas musculares de glicogênio pode culminar em sua exaustão. Uma enzima conhecida por creatina-fosfoquinase (CPK) pode ser utilizada para medir a exaustão muscular (SHAW; TUME, 1992). Associados, o lactato, a creatinafosfoquinase e o cortisol podem ser medidos como indicadores fisiológicos para aferir estresse em suínos.

Quando o animal sofre um estresse crônico, as reservas de glicogênio muscular diminuem e, consequentemente, no abate, a carne sofrerá com uma baixa acidificação. Com o pH acima de 6,0 a carne terá maior capacidade de retenção de líquidos e baixa refletância de luz, dando a carne uma aparência escurecida, firme e seca, situação conhecida como DFD (em inglês, Dark, Firm and Dry. RAMOS; GOMILDE, 2012). Por outro lado, quando o animal sofre um estresse agudo no pré-abate, a conversão de glicogênio em glicose tende a estar acentuada na hora do abate e a produção de ácido lático também estará elevada. Com o pH diminuído, a carne tem menor capacidade de retenção de líquido e maior refletância da luz (WISMER-PEDERSEN, 1987), dando à carne uma aparência pálida, mole e exsudativa, condição conhecida como PSE (em inglês, Pale, Soft and Exsudative. RAMOS; GOMILDE, 2012).

Algumas variáveis podem ser utilizadas para aferir a qualidade da carne, como o pH e temperatura ao abate, $\mathrm{pH}$ e temperatura 24 horas após o abate, cor, perda de água por exsudação, perda de água por cocção, marmoreio, força de cisalhamento e análise dos

microelementos presentes na carne. Outras variáveis relacionadas ao rendimento e qualidade de carcaça e de carne podem ser aferidas: comprimento de carcaça, perda de peso por resfriamento, espessura de toucinho e área de olho de lombo (BRIDI, 2009). 
Objetivou-se averiguar a concentração de indicadores bioquímicos e físicos da qualidade da carne de suínos que receberam tratamento aversivo ou controle. Esperava-se encontrar problemas na qualidade de carne de leitões que receberam o tratamento aversivo, visto que estes animais sofreram com estresse crônico e demonstraram padrão comportamental indicativo de estresse durante as fases de maternidade, creche e crescimento/terminação.

\subsection{METODOLOGIA}

Amostras sanguíneas para análise de lactato foram colhidas quatro vezes: no dia do desmame, na mudança da sala de creche para a sala de crescimento/terminação, no dia préabate e no dia do abate (durante a sangria). Nas medidas do dia do desmame e no dia de mudança da sala de creche para a sala de crescimento/terminação, assumiu-se dois tratamentos (controle e aversivo) visto que os animais do tratamento misto e do tratamento aversivo recebiam o mesmo tratamento (aversivo). Uma gota de sangue da veia marginal da orelha esquerda foi colhida através de um pique com a ponta de uma agulha $25 \times 8$ e lida através do aparelho Lactate Scoult ${ }^{\circledR}$ (Figura 21), que mostrava o resultado na hora da colheita (validado por ROCHA et al., 2014). Os animais receberam jejum de 18 horas antes do abate, tendo água à disposição até a hora do embarque.

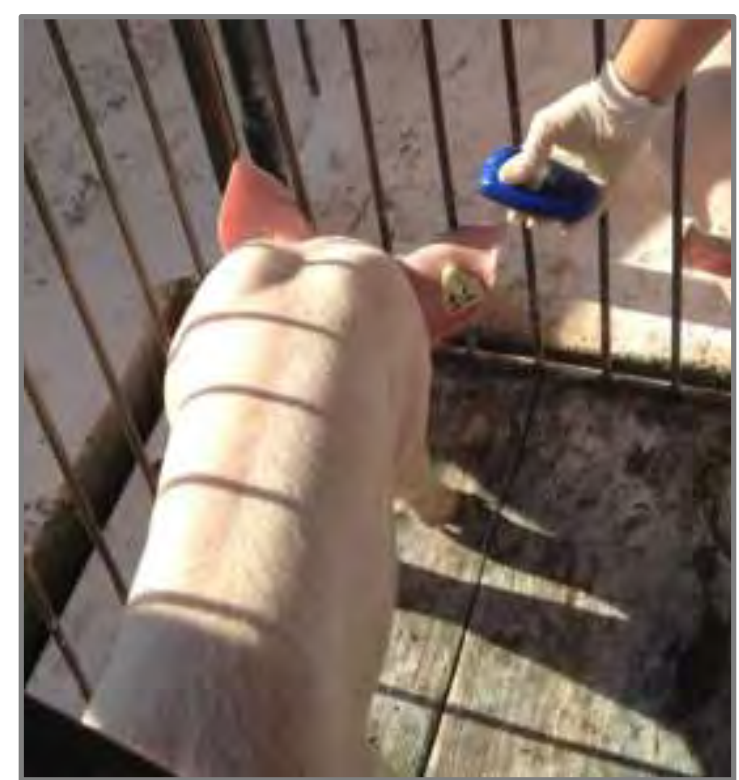

Figura 21 - Uso do Lactate Scoult ${ }^{\circledR}$ para aferir lactato durante as pesagens. 
O abate ocorreu em dois dias sequenciais. A cada dia, 24 animais foram abatidos, totalizando 48 animais (8 TA com enriquecimento, 8 TA sem enriquecimento, 8 TC com enriquecimento, 8 TC sem enriquecimento, 8 TM com enriquecimento e 8 TM sem enriquecimento). Os animais foram transportados da granja para o abatedouro em um caminhão, sem divisão por tratamento (Figura 22a). O trajeto entre a granja e o abatedouro media menos de $2 \mathrm{~km}$ e demorou cerca de $5 \mathrm{~min}$. Assim que chegaram ao abatedouro, os suínos foram descarregados numa baia de espera e permaneceram neste local poucos minutos até a hora do abate (Figura 22b). Os animais entravam na sala de abate em grupos de 4 a 5 animais e eram atordoados individualmente com choque de $400-450 \mathrm{~V}$ e 2-1,78 A.

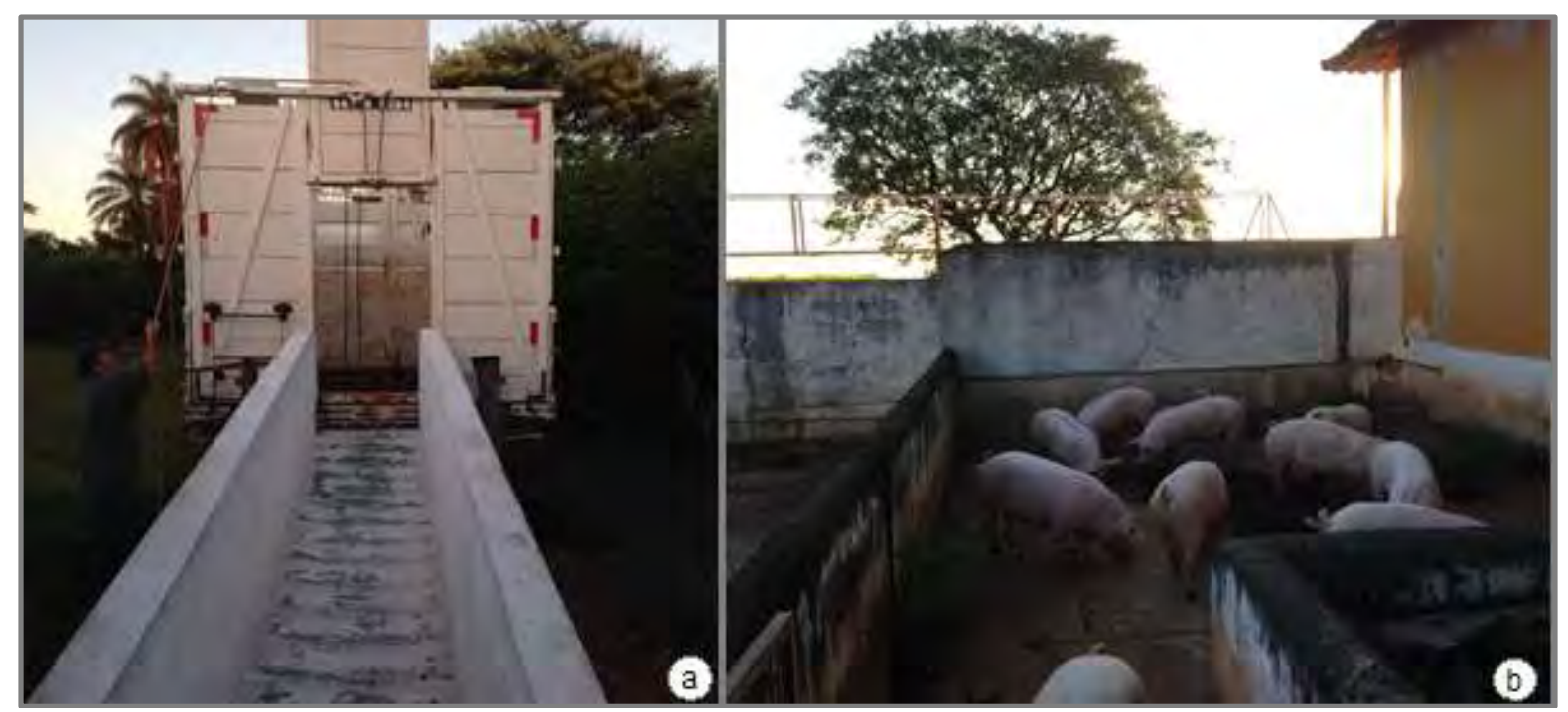

Figura 22 - a) caminhão utilizado para transportar os animais da granja para o abatedouro; b) animais na baia de espera no abatedouro.

Durante a sangria, $10 \mathrm{ml}$ de sangue foram colhidos para análise de CPK e cortisol séricos realizada em laboratório comercial, além da análise do lactato realizado através do Lactate Scoult ${ }^{\circledR}$. Após uma hora do abate foram medidos o pH, a temperatura e o peso da carcaça quente. Após 24 horas, a medida de pH, a temperatura de carcaça e o peso de carcaça (então denominado peso de carcaça resfriada) foram repetidas. Além dessas colheitas, no dia posterior ao abate, foram medidos os comprimentos de carcaça, as 
espessuras de toucinho, as áreas de olho de lombo, as cores e foram colhidas amostras para analisar a perda de água por gotejamento (drip loss), perda de água por cocção e maciez.

\subsubsection{Avaliação quantitativa da carcaça}

\subsubsection{Peso e rendimento de carcaça}

As carcaças inteiras foram pesadas logo após o abate (peso de carcaça quente) e com 24 horas de abate (peso de carcaça fria). Durante as primeiras 24 horas após o abate, as carcaças foram alojadas na câmara fria do Matadouro Escola e ficaram em temperatura entre $0^{\circ} \mathrm{Ce} 4^{\circ} \mathrm{C}$.

Para o cálculo de rendimento de carcaça e perda de carcaça no resfriamento, foram utilizadas as seguintes equações:

Rendimento de carcaça $(\%)=\frac{\text { Peso de carcaça quente } X 100}{\text { Peso vivo ao abate }}$

Perda de carcaça no resfriamento $(\%)=100-\left(\frac{\text { Perda de carcaça resfriada X } 100}{\text { Peso de carcaça quente }}\right)$

\subsubsection{2. $\quad$ Área de olho de lombo e espessura de toucinho}

A meia carcaça esquerda foi seccionada transversalmente na altura entre a $10^{\mathrm{a}}$ e $11^{\mathrm{a}}$ costela e duas amostras de $2,5 \mathrm{~cm}$ de altura foram colhidas. Da primeira amostra fez-se a mensuração da área de olho de lombo ( $\mathrm{AOL}$ ), cor e perda de água por gotejamento; da segunda amostra, fez-se a análise da perda de água por cocção e maciez. A espessura de toucinho foi aferida na altura da última costela, perpendicular à linha dorso-lombar, onde a espessura do tecido adiposo foi medida com o auxílio de uma fita métrica (Figura 23a). A área de olho de lombo (ou área do músculo Longissimus dorsi - LD) foi mensurada através de foto-análise pelo programa Lince versão 1.2.0. (Figura 23b). 


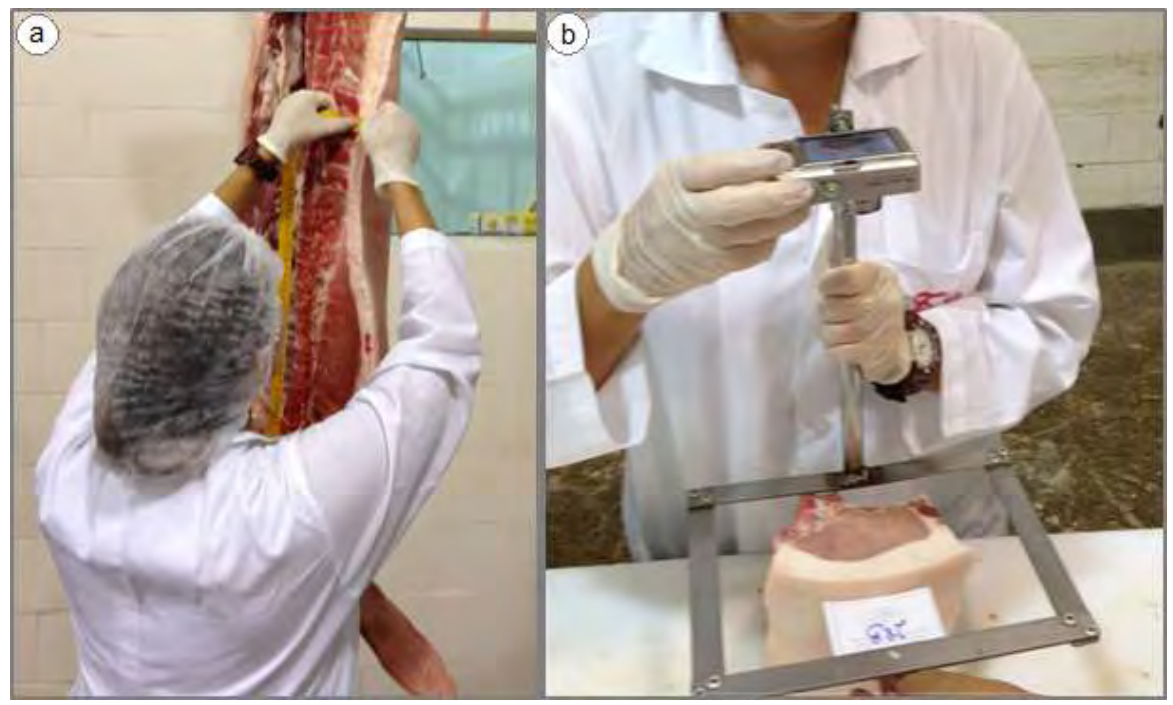

Figura 23 - Mensuração de espessura de toucinho (a) e área de olho de lombo (b).

\subsubsection{Avaliação qualitativa da carcaça}

\subsubsection{1. $\quad$ pH e temperatura de carcaça}

$\mathrm{O} \mathrm{pH}$ e a temperatura de carcaça foram medidos no músculo LD na altura da última costela, utilizando um peagâmetro com termômetro acoplado a uma sonda de penetração (modelo HI-99163, Hanna, São Paulo. Figura 24a). Foram realizadas duas colheitas: a primeira foi realizada 1 hora após o abate, e a segunda, 24 horas após o abate. 0 couro do animal, juntamente com a gordura subcutânea foi perfurado com uma faca antes de introduzir a sonda no músculo para fazer a leitura.

\subsubsection{2. $\quad$ Cor}

Após a retirada da fotografia para análise de $A O L$, a amostra ficou em repouso, com a superfície exposta ao ar por 20 minutos para que o músculo sofresse oxigenação (ABULARACH et al., 1998). Então, foi realizada a mensuração da cor em três pontos distintos da superfície do músculo LD (Figura 24b). Para tal, foi utilizado um colorímetro portátil (modelo MiniScan XE, Kinica Minolta, São Paulo, Brasil), com fonte de luz de D65, ângulo de observação de $10^{\circ}$ e abertura de célula de medida de $10 \mathrm{~mm}$. Foi utilizada a escala $\mathrm{L}^{*}, \mathrm{a}^{*}, \mathrm{~b}^{*}$ do sistema CIELab, sendo que $L^{*}$ está associada a luminosidade ( $L^{*}=0$ preto, $L^{*}=100$ branco), 
a* é a croma que varia do verde (-) ao vermelho (+), e o b* é a croma que varia do azul (-) ao amarelo (+) (HOUBEN et al., 2000). O aparelho foi calibrado antes da leitura das amostras.

\subsubsection{Drip loss ou perda de água por gotejamento}

Ao final da análise de cor, foram retirados dois cilindros de carne da amostra ( $25 \mathrm{~mm}$ cada) com a ajuda de uma ferramenta (vazador) afiada e cilíndrica que cortava a carne sem macerar as bordas do corte (Figura 24c). Cada amostra cilíndrica foi colocada em um contêiner especial para análise de perda de água por gotejamento (EZ-Drip Loss Container, EUA) e armazenada em ambiente refrigerado com temperatura entre $0^{\circ} \mathrm{C}$ e $4^{\circ} \mathrm{C}$, por 48 horas. Os contêineres foram pesados antes de receberem as amostras e depois de receberem as amostras. A diferença entre estas duas medidas demonstrava o peso da amostra (DLi). Após as $48 \mathrm{~h}$ de refrigeração, a amostra foi pesada sem o contêiner (DLf) e a diferença de peso entre DLf - DLi determinou a perda de água por gotejamento (CORREA; MÉTHOT; FAUCITANO, 2007).

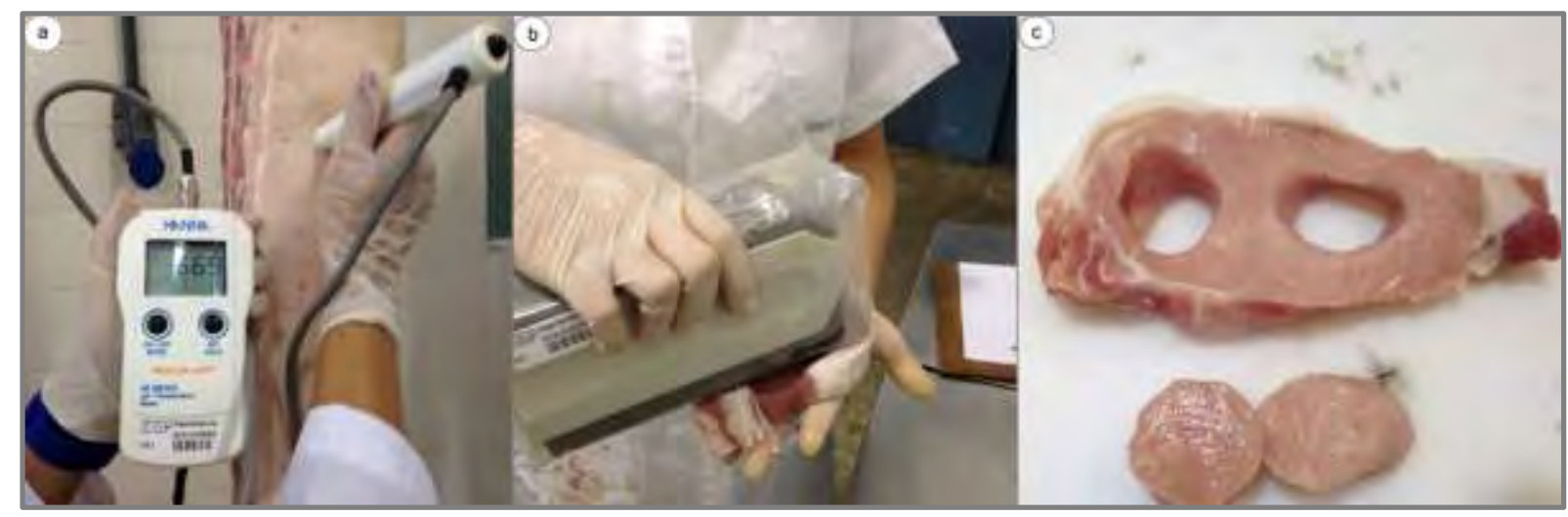

Figura 24 - a) aferição de pH; b) cor; c) colheita de amostra para análise de perda de água por gotejamento.

\subsubsection{Perda de água por cocção e maciez}

Uma amostra de carne que havia sido congelada para posterior análise foi utilizada para medir a perda de água por cocção e a maciez. Para tal, as amostras foram 
descongeladas sob refrigeração $\left(4^{\circ} \mathrm{C}\right)$. Após, foram colocadas em bandejas de alumínio individuais (Figura 25a) para que fossem pesadas (o peso da bandeja foi descartado) antes e depois de assar. A perda de água por cocção pode ser medida através da fórmula:

Perda de água por $\operatorname{coc} c ̧ a ̃ o(\%)=\left(\frac{\text { Peso inicial }- \text { Peso final da amostra }}{\text { Peso inicial da amostra }}\right) \times 100$

O peso inicial da amostra é mensurado antes da amostra ser assada e o peso final é o peso da amostra após cozimento. As amostras foram assadas em forno elétrico (Figura 25b) com temperatura de $170^{\circ} \mathrm{C}$ até atingirem a temperatura interna de $45^{\circ} \mathrm{C}$, quando foram viradas até atingirem a temperatura de $71^{\circ} \mathrm{C}$. A temperatura interna das amostras foi media com termômetro do tipo sensor de metal em forma de agulha (GLOBO, Americana, São Paulo, Brasil). Depois de cozidas, as amostras ficaram em repouso sob temperatura ambiente até alcançarem temperatura interior de $20^{\circ} \mathrm{C}$, quando foram pesadas para se obter o peso final.

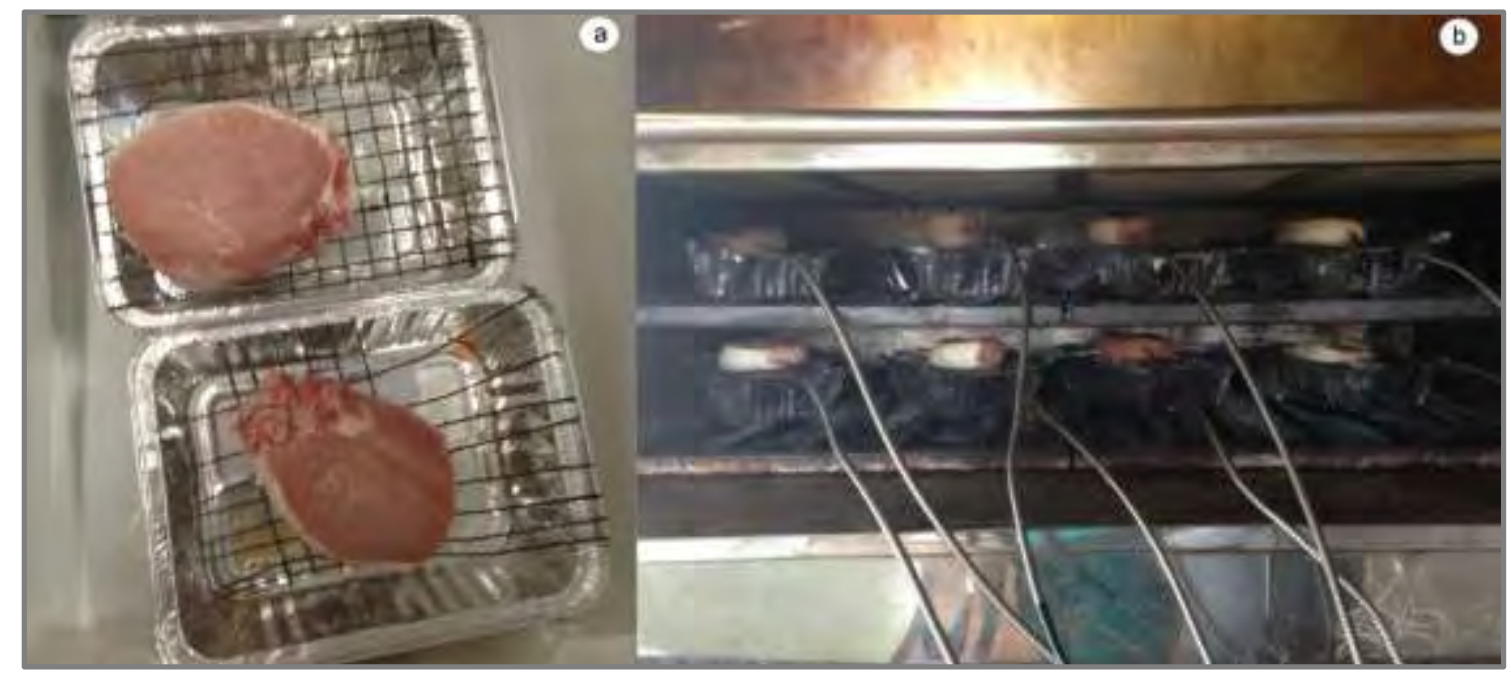

Figura 25 - Perda de água por cocção: a) amostra antes de assar; b) amostra dentro do forno de cozimento. 
Para a maciez, estas mesmas amostras foram utilizadas após a pesagem final. Elas foram resfriadas por $12 \mathrm{~h}$ sob $4^{\circ} \mathrm{C}$. Então, foram extraídos seis cilindros de $12 \mathrm{~mm}$ de diâmetro (Figura 26) de cada amostra, com o auxílio de um vazador próprio para este procedimento. Estes cilindros foram cisalhados no Warner-Bratzler Sher Force (G-R MANUFACTURING C.O., Manhatan, Kansas, EUA) para a determinação da forca de cisalhamento. A maciez é o resultado da média das seis amostras.

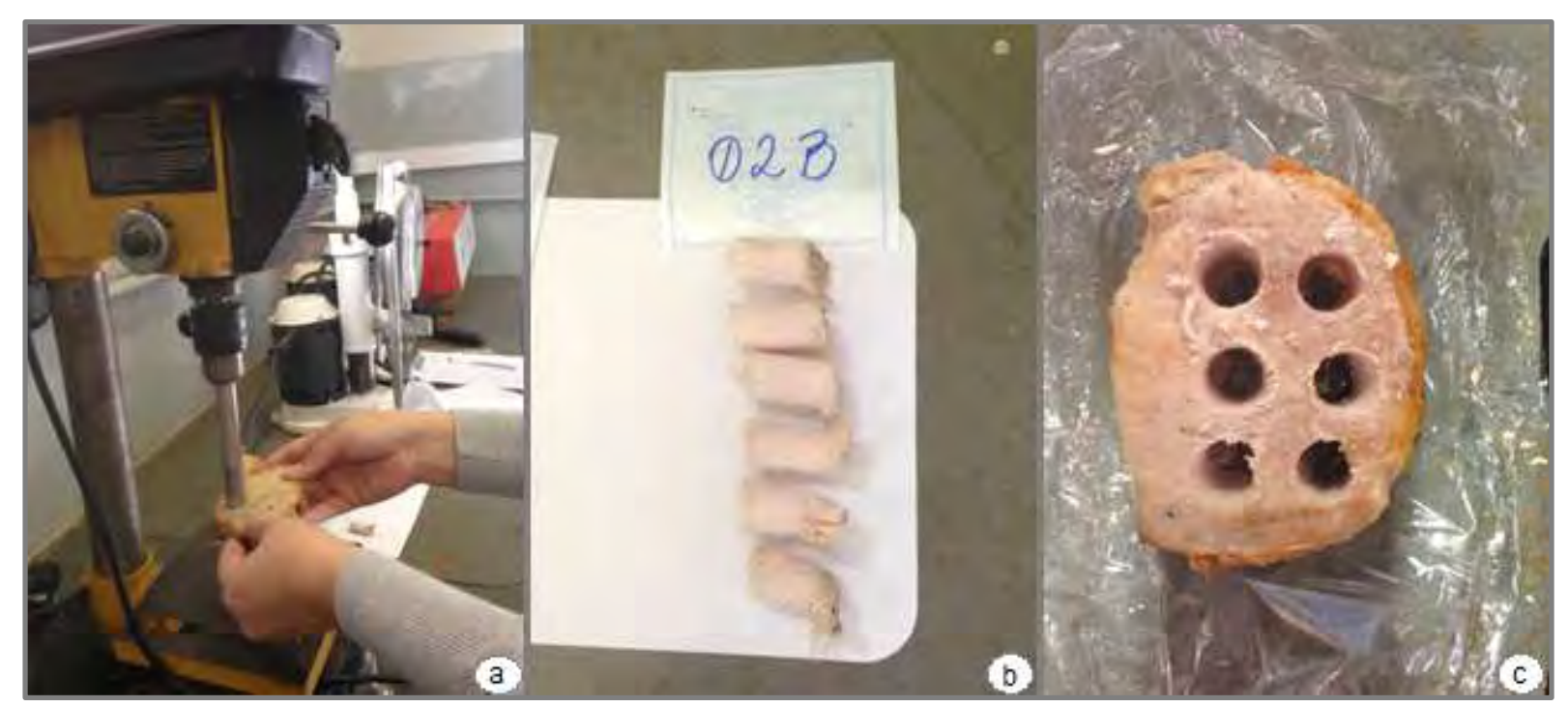

Figura 26: Maciez: a) retirada dos cilindros da amostra b) cilindros de amostra antes do cisalhamento; c) disposição dos cilindros dentro da amostra.

\subsection{RESULTADOS}

\section{Análise sanguínea}

No dia do desmame, animais que receberam tratamento controle demonstraram maior valor de lactato (Figura 27). Não houve diferença na medida de lactato durante a mudança de ambiente da sala de creche para a sala de crescimento/terminação. No dia préabate, os animais em TM obtiveram maior valor de lactato e os animais em TC tiveram o menor valor. Já no dia do abate, durante a sangria, os animais TA obtiveram maior valor de lactato do que os leitões controle. 


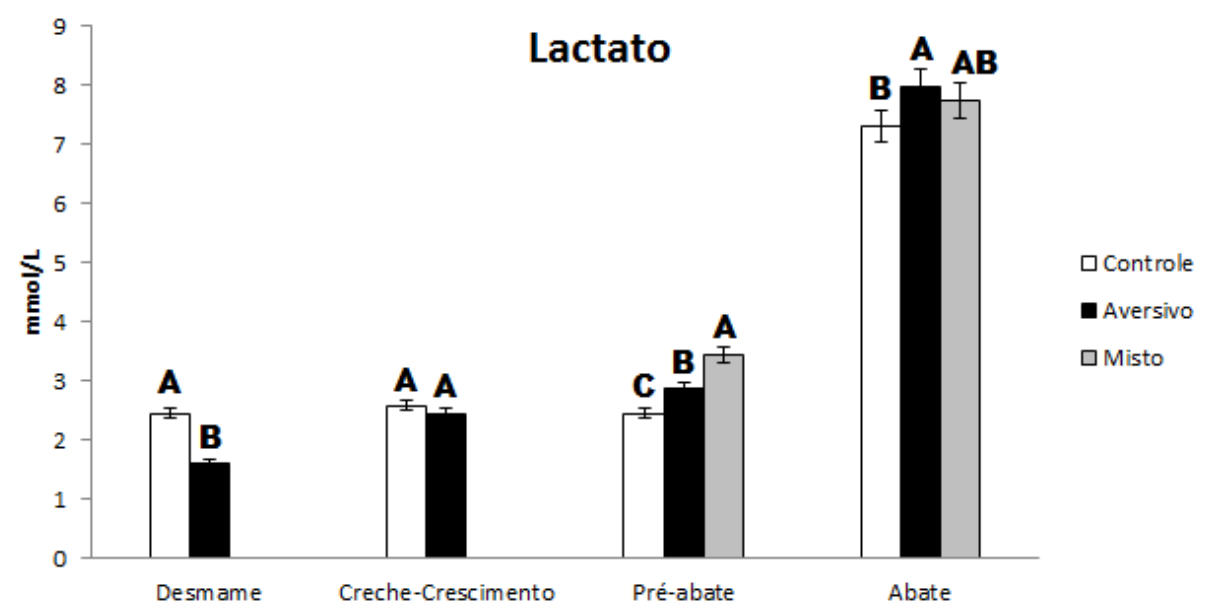

Figura 27 - Média dos valores de lactato $\left(\mu \mathrm{Mol} . \mathrm{g}^{-1}\right)$ encontrado em leitões tratados de forma aversiva, mista e controle no dia do desmame, na mudança de sala da creche para a sala de crescimento/terminação, no dia pré-abate e no dia do abate.

Não houve diferença para as concentrações de cortisol e de CPK $(P>0,05)$ entre animais tratados de forma aversiva, mista ou controle, nem entre animais que receberam enriquecimento e os que não receberam enriquecimento (Tabela 12).

Tabela 12 - Concentração de cortisol $\left(\mu \mathrm{g} \cdot \mathrm{dL}^{-1}\right)$ e $\mathrm{CPK}\left(\mathrm{U} \cdot \mathrm{L}^{-1}\right)$ para suínos que receberam tratamento controle, misto, aversivo, com enriquecimento (CE) e sem enriquecimento (SE).

\begin{tabular}{lcc}
\hline \multicolumn{1}{c}{ Tratamentos } & Cortisol $\left(\boldsymbol{\mu g} \cdot \mathbf{d L}^{-1}\right)$ & CPK $\left(\mathbf{U}^{-1} \mathbf{L}^{-1}\right)$ \\
\hline Controle & $12,25 \pm 1,2$ & $2209,69 \pm 200,36$ \\
Misto & $10,97 \pm 1,2$ & $2582,25 \pm 193,56$ \\
Aversivo & $13,3 \pm 1,2$ & $2112,56 \pm 193,56$ \\
CE & $12,17 \pm 1,0$ & $2237,08 \pm 158,04$ \\
SE & $12,18 \pm 1,0$ & $2365,92 \pm 161,76$ \\
\hline
\end{tabular}

Para todos os valores, $\mathrm{P}>0,05$.

Análise de qualidade de carne

Não houve diferença em nenhuma variável analisada para aferir qualidade de carne $(P>0,05)$. As variáveis analisadas, suas médias e erros padrão estão dispostos na Tabela 12. Apesar de não haver diferença, os resultados referentes a pH 1 hora, pH 24 horas, cor e drip loss sugerem a presença de carne PSE em todos os tratamentos (Tabela 13). 
Tabela 13 - Média e erro padrão das variáveis analisadas para aferir qualidade de carne e de carcaça para animais que receberam tratamento controle, misto ou aversivo, com enriquecimento (CE) ou sem enriquecimento (SE).

\begin{tabular}{lccccc}
\hline \multicolumn{1}{c}{ Variáveis Analisadas } & Controle & Misto & Aversivo & CE & SE \\
\hline pH - 1 hora & $6,21 \pm 0,04$ & $6,27 \pm 0,04$ & $6,13 \pm 0,04$ & $6,17 \pm 0,36$ & $6,24 \pm 0,36$ \\
Temperatura - 1 hora $\left({ }^{\circ} \mathbf{C}\right)$ & $31,57 \pm 0,25$ & $31,63 \pm 0,25$ & $31,58 \pm 0,25$ & $31,43 \pm 0,19$ & $31,76 \pm 0,19$ \\
Peso da carcaça quente $(\mathbf{k g})$ & $80,95 \pm 0,74$ & $81,12 \pm 0,74$ & $83,64 \pm 0,74$ & $81,55 \pm 0,60$ & $82,26 \pm 0,60$ \\
pH - 24 horas & $5,59 \pm 0,05$ & $5,55 \pm 0,04$ & $5,55 \pm 0,05$ & $5,59 \pm 0,35$ & $5,54 \pm 0,35$ \\
Temperatura - 24 horas $\left({ }^{\circ} \mathbf{C}\right)$ & $8,34 \pm 0,23$ & $8,46 \pm 0,23$ & $8,81 \pm 0,23$ & $8,83 \pm 0,20$ & $8,24 \pm 0,19$ \\
Peso da carcaça fria (kg) & $79,07 \pm 0,75$ & $79,54 \pm 0,75$ & $81,16 \pm 0,75$ & $79,63 \pm 0,61$ & $80,22 \pm 0,61$ \\
Rendimento de carcaça (\%) & $80,62 \pm 1,27$ & $80,54 \pm 1,27$ & $82,06 \pm 1,20$ & $80,69 \pm 1,27$ & $81,46 \pm 1,35$ \\
Perda por resfriamento (\%) & $2,35 \pm 0,5$ & $2,34 \pm 0,3$ & $2,23 \pm 0,1$ & $2,36 \pm 0,04$ & $2,22 \pm 0,06$ \\
Perda de água por cocção (\%) & $30,85 \pm 0,76$ & $31,76 \pm 0,77$ & $32,21 \pm 0,75$ & $31,60 \pm 0,49$ & $31,61 \pm 0,82$ \\
Maciez (kg) & $3,82 \pm 1,15$ & $3,91 \pm 1,15$ & $4,03 \pm 1,16$ & $3,98 \pm 1,12$ & $3,86 \pm 1,12$ \\
Drip loss (\%) & $6,3 \pm 0,66$ & $7,33 \pm 0,74$ & $6,87 \pm 0,63$ & $7,34 \pm 0,55$ & $6,33 \pm 0,52$ \\
Área de olho de lombo (cm $\left.{ }^{2}\right)$ & $38,77 \pm 1,25$ & $37,72 \pm 0,89$ & $38,86 \pm 0,86$ & $38,8 \pm 1,52$ & $38,1 \pm 1,01$ \\
Espessura de toucinho (cm) & $1,49 \pm 0,1$ & $1,41 \pm 0,06$ & $2,30 \pm 0,98$ & $2,07 \pm 0,11$ & $1,39 \pm 0,10$ \\
Cor L & $53,34 \pm 0,96$ & $53,29 \pm 0,95$ & $52,58 \pm 0,98$ & $52,87 \pm 0,87$ & $53,27 \pm 1,05$ \\
Cor a & $-0,36 \pm 0,25$ & $0,33 \pm 0,23$ & $0,19 \pm 0,22$ & $0,001 \pm 0,25$ & $0,11 \pm 0,26$ \\
Cor b & $7,22 \pm 0,30$ & $7,64 \pm 0,32$ & $7,29 \pm 0,36$ & $7,35 \pm 0,31$ & $7,41 \pm 0,31$ \\
\hline
\end{tabular}

Para todos os valores, $\mathrm{P}>0,05$.

Tabela 14 - Classificação da carne suína (WARNER; KAUFFMAN; GREASER, 1997) de acordo com o tratamento recebido: controle, misto, aversivo, com enriquecimento (CE) ou sem enriquecimento (SE), com máximos e mínimos valores encontrados dentro de cada tratamento.

\begin{tabular}{lcccc}
\hline \multicolumn{1}{c}{ Variáveis } & $\mathbf{p H}-\mathbf{1}$ hora & $\mathrm{pH}-\mathbf{2 4}$ horas & Cor L & Drip loss (\%) \\
\hline Controle & $6,21 \pm 0,04$ & $5,59 \pm 0,05$ & $53,34 \pm 0,96^{\text {PSE }}$ & $6,3 \pm 0,66^{\text {PSE }}$ \\
Máximo & 6,86 & 5,77 & $64,13^{\text {PSE }}$ & $11,49^{\text {PSE }}$ \\
Mínimo & 5,8 & $5,45^{\text {PSE }}$ & 49,41 & $1,77^{\text {DFD }}$ \\
\hline Misto & $6,27 \pm 0,04$ & $5,55 \pm 0,04^{\text {PSE }}$ & $53,29 \pm 0,95^{\text {PSE }}$ & $7,33 \pm 0,74^{\text {PSE }}$ \\
Máximo & 6,8 & 5,64 & $61,93^{\text {PSE }}$ & $11,87^{\text {PSE }}$ \\
Mínimo & $5,68^{\text {PSE }}$ & $5,44^{\text {PSE }}$ & 47,19 & $3,17^{\text {DFD }}$ \\
\hline Aversivo & $6,13 \pm 0,04$ & $5,55 \pm 0,05^{\text {PSE }}$ & $52,58 \pm 0,98^{\text {PSE }}$ & $6,87 \pm 0,63^{\text {PSE }}$ \\
Máximo & 6,74 & 5,71 & $62,33^{\text {PSE }}$ & $10,09^{\text {PSE }}$ \\
Mínimo & 5,81 & $5,08^{\text {PSE }}$ & 46,07 & $3,11^{\text {DFD }}$ \\
\hline CE & $6,17 \pm 0,36$ & $5,59 \pm 0,35$ & $52,87 \pm 0,87^{\text {PSE }}$ & $7,34 \pm 0,55^{\text {PSE }}$ \\
Máximo & 6,86 & 5,79 & $61,93^{\text {PSE }}$ & $11,87^{\text {PSE }}$ \\
Mínimo & $5,68^{\text {PSE }}$ & $5,5^{\text {PSE }}$ & 46,07 & $3,33^{\text {DFD }}$ \\
\hline SE & $6,24 \pm 0,36$ & $5,54 \pm 0,35^{\text {PSE }}$ & $53,27 \pm 1,05^{\text {PSE }}$ & $6,33 \pm 0,52^{\text {PSE }}$ \\
Máximo & 6,82 & 5,77 & $64,13^{\text {PSE }}$ & $11,49^{\text {PSE }}$ \\
Mínimo & 5,81 & $5,08^{\text {PSE }}$ & 47,49 & $1,77^{\text {DFD }}$ \\
\hline
\end{tabular}

PSE: Valor indicativo de PSE. ${ }^{\text {DFD }}$ : Valor indicativo de DFD. Valores sem marcação são indicativos de carne normal. São apresentadas médias e erros padrões dos tratamentos e o número absoluto de máximo e mínimo dentro de cada tratamento. 


\subsection{DISCUSSÃO}

Não houve diferença na análise de qualidade da carne de leitões tratados de forma aversiva, mista ou controle, nem entre os animais que receberam enriquecimento ambiental e os que não receberam, mesmo que o padrão comportamental destes grupos de animais tenha diferido como discutido anteriormente nas seções 6, 7 e 8 . Como o tempo de transporte e o tempo de espera pré-abate não foram suficientes para que os animais se recuperassem do estresse do transporte, acredita-se que o estresse agudo deste evento possa ter mascarado o estresse crônico sofrido pelos leitões que receberam tratamento aversivo e os que não receberam enriquecimento ambiental. Provavelmente, devido a esse estresse no pré-abate, todos os tratamentos tiveram carne com indicadores de PSE, seja no pH inicial, no pH final, na coloração ou no drip loss.

Todos os animais abatidos sofreram com o baixo tempo de transporte (cerca de 5 minutos) e a mistura de grupo. Suínos de terminação transportados por pouco tempo não conseguem se recuperar do estresse causado pelo embarque e acabam por sofrer mais no pequeno percurso (PÉREZ et al., 2002). Além disso, os animais não tiveram muito tempo de descanso na baia pré-abate, pois chegaram e logo foram abatidos. Animais que descansam ao menos 2 horas antes do abate conseguem se recuperar do transporte de forma mais eficiente do que aqueles que são abatidos imediatamente (PÉREZ et al., 2002). Mesmo que na literatura a carne DFD esteja associada ao estresse crônico, a detecção desta situação na qualidade da carne de suínos parece ser menos frequente e, muitas vezes, mascarada pelo estresse agudo dos eventos pré-abate (jejum, embarque, transporte, desembarque e espera), onde a carne PSE acaba sendo detectada (RAMOS; GOMIDES, 2012).

Provavelmente, esta seja também a causa de o cortisol e o CPK medidos na sangria não terem demonstrado diferença entre os tratamentos e terem apresentado valores elevados em comparação com demais estudos. Os valores encontrados para CPK neste estudo são superiores aos encontrados por Brandt e Aaslyng (2015), que encontraram 1549 \pm 379 U. $L^{-1}$ de CPK durante a sangria; e superiores ao valor de $1436 \pm 194,4$ U. $L^{-1}$ encontrado por Warriss e colaboradores (1994) em animais sob alto índice de estresse. A concentração de cortisol sanguínea encontrada neste estudo é o dobro do valor de 6,96 $\pm 0,18 \mu \mathrm{g} \cdot \mathrm{dL}^{-1}$, encontrado durante a sangria por Brandt e Aaslyng (2015). 
Já em relação à concentração de lactato medida ao longo da vida dos animais, podese notar algumas diferenças interessantes. No desmame, animais que receberam o tratamento controle tiveram maior concentração de lactato, mas essa diferença não foi detectada no pré-abate e no momento da sangria, onde os animais em TC apresentaram menores concentrações de lactato do que os animais que receberam TA e TM. Estes valores elevados de lactato em TM e em TA deveriam modificar a acidez muscular destes tratamentos e trazer diferença na qualidade da carne analisada, fato que não foi observado, provavelmente devido ao manejo estressante no pré-abate.

Os trabalhos disponíveis que relacionam um tratamento aversivo à qualidade da carne relatam interações negativas agudas como o uso de bastão de choque (D'SOUZA et al., 1998; DOKMANOVIĆ et al., 2014), e não trazem interações crônicas com um tratador aversivo, como usado em nosso trabalho. Dokmanović e colaboradores (2014) compararam baixo tempo de espera (mínimo de 8 minutos) com alto tempo de espera (máximo de 27,5 horas) e a presença ou não de um tratamento aversivo (com uso de bastão elétrico) no préabate. Concluíram que o menor tempo de espera e a presença de um tratamento aversivo no pré-abate aumentam a concentração de lactato e pioram a qualidade de carne.

\subsection{CONCLUSÃO}

Sob condições de baixo tempo de transporte e baixo tempo de espera pré-abate, não foi possível detectar diferença de variáveis relacionadas à qualidade da carcaça e da carne de suínos tratados de forma aversiva, controle ou mista, com ou sem enriquecimento. No entanto, considerando as diferenças comportamentais observadas nesses animais, que indicam um estado prolongado de estresse, acreditamos que diferenças na qualidade de carne e rendimento de carcaça possam ser identificadas, utilizando uma amostra maior de animais ou condições padrão de pré-abate. Assim, encorajamos a realização de outras pesquisas nesta área. 


\section{DISCUSSÃO GERAL}

Numa visão geral, os animais que receberam tratamento aversivo foram mais ativos e apresentaram elevadas frequências de interações agonísticas, observadas em todas as fases de criação. Além disso, estes animais apresentaram maior incidência de belly-nosing no pósdesmame, maior frequência de atividade no Teste de Área Desconhecida, menor frequência e tempo de contato com o objeto no Teste do Novo Objeto. Estes animais mantiveram maior distância de seu tratador habitual aversivo e, quando ficaram três semanas sem contato com esta pessoa, mantiveram esta resposta de evitação. Já os animais que receberam enriquecimento ambiental apresentaram maior frequência de comportamentos exploratórios.

Os leitões tratados de forma aversiva mantiveram as frequências de interações, mesmo sem ter sofrido mistura de lote. Suínos são animais gregários, com uma hierarquia estável e linear (JENSEN; WOOD-GUSH, 1984). Assim que desmamados e levados a uma nova instalação, a observação de interações agonísticas é comum nas primeiras horas, mesmo não havendo mistura de leitegada (MASON; JARVIS; LAWRENCE, 2003), pois os animais precisam estabelecer uma nova hierarquia na ausência da mãe (JARVIS et al., 2008). Após o estabelecimento da hierarquia, se o grupo não for modificado, as frequências das interações agonísticas tendem a diminuir, visto que suínos reconhecem seus parceiros de grupo (MENDL et al., 2001; MCLEMAN et al., 2008). Essa diminuição das interações agonísticas não foi observada no presente estudo no grupo de animais tratados de forma aversiva. É possível que o estresse contínuo que os animais receberam desde que nasceram tenha influenciado a percepção dos animais e o reconhecimento social (SOUZA; ZANELLA, 2008; HÖTZEL et al. 2011), explicando as interações agonísticas. Somado a isso, estes animais apresentaram maior frequência de comportamentos anômalos, sugerindo uma resposta mais severa ao estresse causado pelo desmame precoce e abrupto (WEARY; APPLEBY; FRASER, 1999).

Quando confrontados com o tratador aversivo num teste de aproximação humana, os leitões tratados de forma aversiva mantiveram maior distância desta pessoa, mas não evitaram a aproximação de uma pessoa desconhecida, parecendo reconhecer e evitar o 
tratador habitual, corroborando os resultados de alguns pesquisadores que sugerem que suínos podem reconhecer humanos (TANIDA et al., 1995; KOBA; TANIDA, 1999; TANIDA; NAGANO, 1998; KIBA; TANIDA, 2001; BRAJON et al., 2015). Mesmo após três semanas sem contato com o tratador aversivo, estes animais mantiveram a resposta de o evitar num novo teste de aproximação humana: isso sugere que, além de reconhecer e evitar um tratador aversivo, leitões podem se lembrar de uma pessoa que os tratou aversivamente, mesmo após algumas semanas sem contato, corroborando com os achados que Hötzel e colaboradores (2005) fizeram sobre bovinos. Não se sabe quais as pistas que estes animais possam ter utilizado para distinguir esta pessoa, mas a cor da roupa e a estrutura corporal parecem estar associadas a isto (KOBA; TANIDA, 2001). Especula-se, também, que os animais possam ter sofrido um condicionamento respondente, onde o estímulo condicionante seria a cor da roupa ou a pessoa em si, o estímulo eliciador e reforçador seria o tratamento aversivo e a resposta seria a alta frequência de comportamentos indicativos de estresse e a evitação desta pessoa. Esses animais, ao serem testados frente a um novo objeto, se mostraram mais atentos e menos motivados a interagir com o mesmo, além apresentar alta frequência de atividade. A paralisação frente a um objeto desconhecido e a elevada frequência de atividade ao serem expostos a um local desconhecido caracterizam estados emocionais como ansiedade e medo (MURPHY; NORDQUIST; VAN DER STAAY, 2014).

Quando o tratamento aversivo foi cessado e os animais receberam a oportunidade de interagir com um enriquecimento ambiental, o padrão comportamental do grupo mudou. Os animais não apresentaram interações agonísticas e a frequência de comportamentos exploratórios aumentou. Animais criados em ambientes enriquecidos tendem a direcionar sua atenção à exploração do enriquecimento e, assim, diminuem as interações agonísticas contra outros animais (BEATTIE; WALKER; SNEDDON, 1995; BEATTIE; WALKER; SNEDDON, 1996; BEATTIE et al., 2000). Neste caso, o condicionamento responsivo que pode ter acontecido, relacionando o tratamento aversivo ao padrão comportamental dos animais, pode ter se extinguido, permitindo que os animais possam expressar seu padrão comportamental naturalmente exploratório.

Para animais tratados de forma aversiva, o enriquecimento ambiental não foi capaz de diminuir as interações agonísticas e motivar os animais a apresentarem maiores frequências de comportamentos exploratórios naturais aos suínos. A introdução do 
enriquecimento ambiental se mostrou eficaz na diminuição de interações agonísticas (O'CONNELL; BEATTIE, 1999) e comportamentos anormais (BENCH; GONYOU, 2006), sendo responsável em aumentar os comportamentos lúdicos e exploratórios (BEATTIE; WALKER; SNEDDON, 1995). Mesmo que o tratamento aversivo fosse cessado e os animais continuassem a viver num ambiente monótono, seu padrão comportamental não apresentou grandes variações de frequência, continuando a apresentar interações agonísticas e baixa motivação em realizar comportamentos exploratórios. Os animais tratados de forma aversiva, que sofreram com o tratamento prolongado, pareceram estar experimentando um estado emocional semelhante à depressão em humanos, conhecido como "desamparo aprendido" (HURNIK, 1988; HUNZIKER, 2005; RICHTER et al., 2012). Neste caso, os animais se mostram apáticos e sem motivações para realizar os comportamentos que normalmente lhe são naturais.

Não houve diferença na análise de qualidade da carne dos leitões, mesmo que os animais que receberam o tratamento aversivo e os animais que não receberam enriquecimento ambiental tenham apresentado um padrão comportamental indicativo de estresse. Os animais foram transportados por um período curto e não tiveram tempo de espera no período pré-abate. Suínos de terminação transportados por pouco tempo não conseguem se recuperar do estresse do embarque e os animais que não conseguem descansar pelo menos 2 horas antes do abate costumam apresentar carne PSE (PÉREZ et al., 2002). Acredita-se que o estresse agudo sofrido no pré-abate tenha mascarado o estresse crônico sofrido por estes animais e, por isso, todos os tratamentos tenham apresentado carne com indicadores de PSE. 


\section{CONCLUSÃO GERAL}

Leitões tratados de forma aversiva demonstraram um padrão comportamental de alto gasto energético, indicando o elevado estresse sofrido por estes animais, independente de receberem o tratamento apenas nas fases de maternidade e creche, ou um tratamento vitalício. A simples cessação deste tratamento não pareceu ser suficiente para que os animais retomem o padrão comportamental comum à espécie, indicando um efeito residual do tratamento recebido anteriormente. Além disso, animais tratados aversivamente são mais medrosos à novidade, ao isolamento social e ao tratador aversivo. Mesmo não havendo diferença no desempenho e qualidade de carne, estes resultados indicam que interações humano-animais aversivas, durante toda ou parte da vida de leitões criados para abate, empobrece o bem-estar desses animais. Este trabalho também mostra que a adição de enriquecimento ambiental pode reverter o efeito das interações aversivas, resultado num padrão comportamental comparável ao de animais tratados gentilmente durante toda a criação. 


\section{CONSIDERAÇÕES FINAIS}

O presente estudo pode constatar que tratar os animais de forma aversiva, mesmo que este tratamento seja observado apenas em uma fase de vida do animal e seja realizado por apenas uma pessoa dentro da granja, pode trazer resultados duradouros para toda a vida do animal. Um animal mais agressivo e responsivo vai prejudicar a dinâmica do manejo, podendo também trazer prejuízos para a produção.

Mesmo com a similaridade do desempenho e componentes de qualidade de carne, tratar os animais de forma racional é ético e seus benefícios vão além dos índices de desempenho, considerando que são animais domesticados para benefício humano, sendo, então, dependentes dos cuidados dos humanos. Na produção nacional, basicamente composta pela integração e agricultura familiar, a interações entre humanos e animais são bem estreitas e influenciam a vida de ambos. Melhorar esta relação pode resolver problemas de manejo e melhorar o bem-estar de pessoas e animais. 


\section{REFERÊNCIAS BIBLIOGRÁFICAS}

ALGERS, B.; JENSEN, P. Teat stimulation and milk production during early lactation in sows: Effects of continuous noise. Canadian Journal of Animal Science, v.71, p.51-60, 1991.

ANDERSEN, I.L. et al. The effects of weight asymmetry and resource distribution on aggression in groups of unacquainted pigs. Applied Animal Behaviour Science, v.68, p.107-120, 2000.

AREY, D.S.; FRANKLIN, M.F. Effects of straw and unfamiliarity on fighting between newly mixed growing pigs. Applied Animal Behaviour Science, v.45, p.23-30, 1995.

AREY, D.S.; SANCHA, E.S. Behaviour and productivity of sows and piglets in a family system and in farrowing crates. Applied Animal Behaviour Science, v.50, p.135-145, 1996.

BARNARD, C. J. e HURST, J. L. Welfare by design: The natural selection of welfare criteria. Animal Welfare, v.5, p.405-433, 1996.

BARNETT, J.L.; HEMSWORTH, P.H.; NEWMAN, E.A. Fear of humans and its relationships with productivity in laying hens at commercial farms. British Poultry Science, v.33, p.699-710, 1992.

BEATTIE, V.E.; WALKER, N.; SNEDDON; I.A. Effect of rearing environment and change of environment on the behaviour of gilts. Applied Animal Behaviour Science, v.46, p.57-65, 1995.

BEATTIE, V.E.; WALKER, N.; SNEDDON, I.A. An investigation of the effect of environmental enrichment and space allowance on the behaviour and production of growing pigs. Applied Animal Behaviour Science, v.48, p.151-158, 1996.

BEATTIE, V.E. et al. Influence of environmental enrichment on welfare-related behavioural and physiological parameters in growing pigs. Animal Science, v.70, p.443-450, 2000.

BENCH, C.J.; GONYOU, H.W. Effect of environmental enrichment at two stages of development on belly nosing in piglets weaned at fourteen days. Journal of Animal Science, v.84, p.3397-3403, 2006.

BENDALL, J. R. Post mortem changes in muscle. In: BOURNE G.H. The structure and function of muscle. Nova lorque, EUA: Academic Press, 1973. Cap. 5. p.243-309.

BENTHAM, J., 1989. A Utilitarian View. In: REGAN, T.; SINGER, P. Animal Rights and Human Obligations. 2a ed. New Jersey: Prentice Hall, 1989.

BITTENCOURT, M. A.; MELLEU, F.F.; MARINO-NETO, J. Stress-induced core temperature changes in pigeons (Columba livia). Physiology \& Behavior, v.139, p.449-458, 2015.

BLOOD, D.C.; STUDDERT, V.P. Dicionário de Veterinária. 2a edição. Editora Guanabara Koogan SA. p.314 e 509, 2002.

BOISSY, A. Fear and fearfulness in animals. The Quarterly Review of Biology, v.70, p.165-191, 1995.

BOKKERS, E.A.M. Effects of interaction between humans and domesticated animals. In: HASSINK, J.; VAN DIJK, M. Farming for Health. Holanda: Wageningen. Cap. 3. p.31-41, 2006. 
BRAJON, S. et al. Persistency of the piglet's reactivity to the handler following a previous positive or negative experience Applied Animal Behaviour Science, v.162, p.9-19, 2015.

BRAMBELL, R. W. R. Report on the Technical Committee of Enquiry into the Welfare of Animals kept under Intensive livestock Husbandry Systems. London: HM Stationery Office, 1965.

BRANDT, P.; AASLYNG, M.D. Welfare measurements of finishing pigs on the day of slaughter: A review. Meat Science, v.103, p.13-23, 2015,

BRIDI, A. M.; SILVA, C. A.; Avaliação da carcaça. In: Avaliação da carne suína. Londrina: Midiograf, 2009. Cap. 1. p. 1-15.

BROOM, D. M. Animal welfare: Concepts and measurement. Journal of Animal Science, v.69, p.41674175, 1991.

BROOM, D.M.; FRASER, A.F. Domestic Animal Behaviour and Welfare. Wallingford, UK: CAB international. 2007, 438pp.

BROWN, S.N. et al. Behavioural and physiological responses of pigs to being transported for up to 24 hours followed by six hours recovery in lairage. Veterinary Record, v.145, p.421-426, 1999.

COLSON, V. et al. Consequences of weaning piglets at 21 and 28 days on growth, behaviour and hormonal responses. Applied Animal Behaviour Science, v.98, p.70-88, 2006.

CORREA, J.A.; MÉTHOT, S.; FAUCITANO, L. A modified meat juice container (EZ-DripLoss) procedure for a more reliable assessment of drip loss and related quality changes in pork meat. Journal of Muscle Foods, v.18, p.67-77, 2007.

CRANSBERG, P.H.; HEMSWORTH, P.H.; COLEMAN, G.J. Human factors affecting the behaviour and productivity of commercial broiler chickens. British Poultry Science, v.41, p.272-279, 2000.

DAMM, B. I.; FORKMAN, B.; PEDERSEN, L.J. Lying down and rolling behaviour in sows in relation to piglet crushing. Applied Animal Behavior Science, v.90, p.3-20, 2005.

DAWKINS, M. S. Behavioural deprivation: A central problem in animal welfare. Applied Animal Behaviour Science, v.20, p.209-225, 1988.

D'EATH, R.B.; TURNER, S.P. The Natural Behaviour of the Pig. In: MARCHANTFORDE, J. N. The Welfare of Pig. Cap. 2. West Lafayette: Springer. 13-46, 2009.

DESCARTES, R. "Le discours de la méthode" Discurso do Método. Tradução: Maria Ermantina Galvão. São Paulo: Livraria Martins Fontes Editora LTDA, 1989.

DEVILLERS, N.; FARMER, C. Behaviour of piglets weaned at three or six weeks of age. Acta Agriculturae Scandinavica Section A-Animal Science, v.59, p.59-65, 2009.

DONALD, R.D. et al. Emotionality in growing pigs: is the open field a valid test? Physiology Behaviour, v.104, p.906-913, 2011.

DOKMANOVIĆ, M. et al. The effects of lairage time and handling procedure prior to slaughter on stress and meat quality parameters in pigs. Meat Science, v.98, n.2, p.220-226, 2014. 
DUNCAN, I. J. H. Welfare is to do whit what animals feel. Journal of Agricultural and Enviromental Ethics, v.6, p.8-14, 1993.

FAGUNDES, A.C.A. et al. Environmental temperature and serum cortisol levels in growing-finishing pigs. Brazilian Journal of Veterinary Research and Animal Science, v.45, p.136-140, 2008.

FORKMAN, B. et al. A critical review of fear tests used on cattle, pigs, sheep, poultry and horses. Physiology \& Behavior, 91:531-565,2007.

FRASER, A. F. Field observations in Jamaica on thermal agalactia in the sow. Tropical Animal Health Production, v.2, p.175-181, 1970.

FRASER, D. The vocalizations and other behaviour of grow-ing pigs in an "open field" test. Applied Animal Ethology, v.1, p.3-16, 1974.

FRASER, D. A review of the behavioural mechanism of milk ejection of the domestic pig. Applied Animal Ethology, v.6, p.247-255, 1980.

FRASER, D. Behavioural perspectives on piglet survival. Journal of Reproduction and Fertility Supplement, v.40, p.355-370, 1990.

FRASER, D. Understanding Animal Welfare: The Schience in its Cultural Context. Oxford, UK: UFAW, 2008.

FRASER, A.F.; BROOM, D.M. Farm Animal Behaviour and Welfare. 3. ed. Reino Unido: Ballière Tindall. 1990. 437pp.

FRASER, D.; JONES, R. M. The 'teat order' of suckling pigs: Relation to birth weigth and subsequent growth. The Journal of Agricultural Science, 84: 387-391. 1975.

GABOR, T.M. et al. Demography, sociospatial behaviour and genetics of feral pigs (Sus scrofa) in a semi-arid environment. Journal of Zoology, v.247, p.311-322, 1999.

GADE, P. B. Pre-slaughter handling. In: JENSEN, W.K. Encyclopedia of meat science. p.1012-1020. Oxford, UK: Elsevier, 2004.

GIELING, E.T.; NORDQUIST, R.E.; VAN DER STAAY, F.J. Assessing learning and memory in pigs. Animal Cognition, v.14, p.151-173, 2011.

GONYOU, H.W. The Social Behaviour of Pigs. In: KEELING, L.J.; GONYOU, H.W. Social behaviour in farm animals. Wallingford: Cab international. p.147-176, 2001.

GONYOU, H.W.; HEMSWORTH, P.H.; BARNET, J.L. Effects of frequent interactions with humans on growing pigs. Applied Animal Behavior Science, v.16, p.269-278, 1986.

GONYOU, H.W. et al. The behaviour of pigs weaned at 12 and 21 days of age from weaning to market. Canadian Journal of Animal Science, v.78, p.517-523 1998.

GOULD, T.D.; DAO, D.T.; KOVACSICS, C.E. The open field test. In: GOULD, T.D. Mood and Anxiety Related Phenotypes in Mice. HumanaPress, New York, NY, pp. 1-120, 2009. 
GRAVES, H.B. Behavior and ecology of wild and feral swine (Sus scrofa). Journal of Animal Science, v.58, p.482-492, 1984.

GREGORY, N.G.; GRANDIN, T. Animal Welfare and Meat Production. Wallingford, UK: CAB international. 400pp, 2007.

HARDING, E.J.; PAUL, E.S.; MENDL, M. Animal behaviour: Cognitive bias and affective state. Nature, v.427, p.312, 2004.

HARRISON, R. Animal Machines. London: Stuart, 1964

HEDIGER, H. (1965) Mensch und Tier im Zoo. Albert-Mu“ Iler Verlag, Ru" schlikon-Zu“ rich. APUD SPOOLDER HAM, WAIBLINGER, S. Pigs and humans. In: MARCHANT-FORDE, J.N. The Welfare of Pig. Cap. 7. West Lafayette: Springer. p.2011-236, 2009.

HELD, S.; COOPER, J.J.; MENDL, M.T. Advances in the Study of Cognition, Behavioural Priorities and Emotions In: MARCHANT-FORDE, J.N. The Welfare of Pig. Cap. 3. West Lafayette: Springer. p.47-94, 2009.

HEMSWORTH, P.H. Behavioural Principles of Pig Handling. In: GRANDIN, T. Livestock Handling and Transport. Cap. 14. Wallingford, UK: CAB International. p.197-221, 1993.

HEMSWORTH, P.H. Human-animal interaction in livestock production. Applied Animal Behaviour Science, v.81, p.185-198, 2003.

HEMSWORTH, P.H.; BARNETT, J.L. The effects of aversively handling pigs, either individually or in groups, on their behaviour, growth and corticosteroids. Applied Animal Behaviour Science, v.30, p.61-72, 1991.

HEMSWORTH, P.H.; COLEMAN, G.J. Human-livestock interactions, the stockperson and the productivity and welfare of intensively farmed animals. Wallingford, UK: CAB International, 2011, 140pp. 1998.

HEMSWORTH, P.H.; BARNETT, J.L.; HANSEN, C. The influence of handling by humans on the behaviour, growth and corticosteroids in the juvenile female pig. Hormones and Behaviour, v.15, p.396-403, 1981.

HEMSWORTH, P.H.; BARNETT, J.L.; HANSEN, C. The influence of handling by humans on the behaviour, reproduction and corticosteroids of male and female pigs. Applied Animal Behaviour Science, v.15, p.303-314, 1986.

HEMSWORTH, P.H.; BARNETT, J.L.; HANSEN, C. The influence of inconsistent handling on the behaviour, growth and corticosteroidis of young pigs. Applied Animal Behaviour Science, v.17, p.245-252, 1987.

HEMSWORTH, P.H.; BARNETT, J.L.; CAMPBELL, R.G. A study of the relative aversiveness of a new daily injection procedure for pigs. Applied Animal Behaviour Science, v.49, p.389-401, 1996.

HEMSWORTH, P.H.; VERGE, J.; COLEMAN, G.J. Conditioned approach-avoidance responses to humans: the ability of pigs to associate feeding and aversive social experiences in the presence of humans with humans. Applied Animal Behaviour Science, v.50, p.71-82, 1996. 
HEMSWORTH, P.H.; COLEMAN G.J; COX, M.; BARNETT J.L. Stimulus generalisation: the inability of pigs to discriminate on the basis of their previous handling experience. Applied Animal Behaviour Science, v.40, p.129-142, 1994.

HEMSWORTH, P.H. et al. Relationships between human-animal interactions and productivity of commercial dairy cows. Journal of Animal Science, v.78, p.2821-2831, 2000.

HENRY, B. A. et al. Disparate effects of feeding on core body and adipose tissue temperatures in animals selectively bred for Nervous or Calm temperament. American Journal of Physiology - Regulatory, Integrative and Comparative Physiology, v.299, n.3, p.907-917, 2010

HÖTZEL, M.J. et al. Behaviour of sows and piglets reared in intensive outdoor or indoor systems. Applied Animal Behaviour Science, v.86, p.27-39, 2004.

HÖTZEL, M.J. et al. Influência de um ordenhador aversivo sobre a produção leiteira de vacas da raça Holandesa. Revista Brasileira de Zootecnia / Brazilian Journal of Animal Science, v. 34, n.4, p. 12781284, 2005.

HÖTZEL, M.J. et al. Estresse e reconhecimento de seres humanos em leitões recém desmamados. Biotemas, 20:91-98, 2007.

HÖTZEL, M.J. et al. 2010. Short-term behavioural effects of weaning age in outdoor-reared piglets. Animal, v.4, p.102-107, 2010.

HÖTZEL, M.J. et al. Disentangling the effects of weaning stressors on piglets' behaviour and feed intake: Changing the housing and social environment. Applied Animal Behaviour Science, v.135, p.44- 50, 2011,

HOUBEN, J.H. et al. Effect of dietary vitamin E supplementation, fat level and packaging on colour stability and lipid oxidation in minced beef. Meat Science, v.55, n.3, p.331-336, 2000.

HURNIK, J. F. Ethics and animal agriculture. Journal of Agricultural and Environmental Ethics, v.6, p.21-35, 1993,

HUNZIKER, M.H.L. O Desamparo Aprendido Revisitado: Estudos com Animais. Psicologia: Teoria e Pesquisa, v.21, n.2, p.131-139, 2005.

HURNIK, J. F. Welfare of Farm Animals. Applied Animal Behaviour Science, v.20, p.105-117, 1988.

JACKSON, P.G.G.; COCKROFT, P.D. Handbook of pig medicine. Edinburgh, Alemanha: Saunders Elsevier, Cap. 7. p.128-142, 2007.

JARVIS S. et al. Effects of weaning age on the behavioural and neuroendocrine development of piglets. Applied Animal Behaviour Science, v.110, p.166-181, 2008.

JENSEN, P. Observations on the maternal behaviour of free-ranging domestic pigs. Applied Animal Behaviour Science, v. 16, p.131-142, 1986.

JENSEN, P.; REBDO I. Behaviour during Nest Leaving in Free-Ranging Domestic Pigs. Applied Animal Behaviour Science, v.18, p.355-362, 1987. 
JENSEN, P.; WOOD-GUSH, D.G.M. Social interactions in a group of free-ranging sows. Applied Animal Behaviour Science, v.12, p.327-337, 1984.

JOHNSON, A.K.; MARCHANT-FORDE, J.N. Welfare of Pigs in the Farrowing Environment. In: MARCHANT-FORDE, J.N. The Welfare of Pig. West Lafayette: Springer. Cap. 5. 141-188, 2009.

KANAAN, V.T. et al. A note on the effects of co-mingling piglet litters on pre-weaning growth, injuries and responses to behavioural tests. Applied Animal Behaviour Science, v.110, p.386-391, 2008.

KANITZ, E. et al. A single exposure to social isolation in domestic piglets activates behavioural arousal, neuroendocrine stress hormones, and stress-related gene expression in the brain. Physiology Behaviour, v.98, p.176-185, 2009.

KELLER, F.S. Aprendizagem: teoria do reforço. São Paulo: E.P.U., 1973, 73pp.

KIRKDEN, R.D.; BROOM, D.M.; ANDERSEN, I.L. INVITED REVIEW: Piglet mortality: Management solutions. Journal of Animal Science, v.91, p.3361-3389, 2014.

KOBA, Y.; TANIDA, H. How do miniature pigs discriminate between people: the effect of exchanging cues between a non-handler and their familiar handler on discrimination. Applied Animal Behaviour Science, v.61, p.239-252, 1999.

KOBA, Y.; TANIDA, H. How do miniature pigs discriminate between people? Discrimination between people wearing coveralls of the same colour. Applied Animal Behaviour Science, v.73, p.45-58, 2001.

LAWRIE, R.A. The conversion of muscle in meat. IN: LAWRIE, R.A.; LEDWARD, D.A. Lawrie's Meat Science. Cambridge, UK. Cap. 5. p.128-156. 2006.

LEBRET, B. et al. Influence of rearing conditions on performance, behavioral, and physiolgical responses of pigs to preslaughter handling, carcass traits, and meat quality. Journal of Animal Science, v.84, p.2436-2447, 2006.

LENSINK, B.J. A Interação humano-animal na produção animal. I Conferência Virtual Global sobre Produção Orgânica de Bovinos de Corte, 2002. Disponível em:

http://www.cpap.embrapa.br/agencia/congressovirtual/pdf/portugues/02pt04.pdf, acesso em 14/03/2015.

LONG, N.C. et al. Stress-Induced Rise of Body Temperature in Rats Is the Same in Warm and Cool Environments. Physiology \& Behavior, v.47, p.773-775, 1990.

MARCHANT-FORDE, J.N. Piglet and stockperson-directed sow aggression after farrowing and the relationship with a pre-farrowing, human approach test. Applied Animal Behaviour Science, v.75, p.115-132, 2002.

MASON, S.P.; JARVIS, J.; LAWRENCE, A.B. Individual differences in responses of piglets to weaning at different ages. Applied Animal Behaviour Science, v.80, p. 117-132, 2003.

MATTERI, R.L.; CARROLL, A.J.; DYER, C.J. Neuroendocrine response to stress IN: MOBERG, G.P.; $\mathrm{MENCH}$, J.A. The biology of animal stress: basic principles and implications for animal welfare. Oxfordshire, UK: CABI. Cap 3. 2000. pp.43-76. 
MCGLONE, J. J. What is animal welfare? Journal of Agricultural and Environmental Ethics, v.6, p.2636, 1993.

MCLEMAN, M.A. et al. Social discrimination of familiar conspecifics by juvenile pigs, Sus scrofa: Development of a non-invasive method to study the transmission of unimodal and bimodal cues between live stimuli Applied Animal Behaviour Science, v.115, p.123-137, 2208.

MENDL, M. Performing under pressure: stress and cognitive function. Applied Animal Behaviour Science, v.65, p.221-244, 1999,

MENDL, M. et al. Animal memory and animal welfare. Animal Welfare, v.10, p. 141-159, 2001

MILLS, D.S. et al. The Encyclopedia of Applied Animal Behaviour and Welfare. EUA: Hardcover. 2010, 704pp.

MORTON, D.B. Encyclopedia of Animal Rights and Animal Welfare. Greenwood Press, p.139-140, 1998.

MOBERG, G.P. Biological response to stress: key to assessment of animal well-being? IN: MOBERG, GP. Animal stress. Bethesda, EUA: American physiological society. Cap. 3. 1985. pp.27-49.

MOTA-ROJAS, D. et al. Effects of mid-summer transport duration on pre-and post-slaughter performance and pork quality in Mexico. Meat Science, v.73, p.404-412, 2006.

MURPHY, E.; NORDQUIST, R.E.; VAN DER STAAY, F.J. A review of behavioural methods to study emotion and mood in pigs, Sus scrofa. Applied Animal Behaviour Science, v.159, p.9-28, 2014.

NELSON D.L.; COX M.M. Lehninger principles of biochemistry, 5th edition, New York, USA: WH Freeman and Company. 2008. 1100pp.

NEWBERRY, R.C., Environmental enrichment: increasing the biological relevance of captive environments. Applied Animal Behaviour Science, v.44, p.229-243, 1995.

NEWBERRY, R.C.; WOOD-GUSH, D.G.M. The suckling behaviour of domestic pigs in a semi-natural environment. Behaviour, v.95, p.11-25, 1985.

NEWBERRY, R.C. AND WOOD-GUSH, D.G.M. Development of some behaviour patterns in piglets under semi-natural conditions. Animal Production, v.46, p.103-109, 1988.

O'CONNELL, N.E. Housing the Fattening Pig In: MARCHANTFORDE, J. N. The Welfare of Pig. Cap. 6. West Lafayette: Springer. p.13-46, 2009.

O'CONNELL, N. E.; BEATTIE, V. E. Influence of environmental enrichment on aggressive behaviour and dominance relationships in growing pigs. Animal Welfare, v.8, p.269-279, 1999.

OVERMIER, J. B. \& SELIGMAN, M. EEffects of inescapable shock upon subsequent escape and avoidance responding. Journal of Comparative and Physiological Psychology, v.63, p.28-33, 1967.

PAJOR, E.A.; FRASER, D.; KRAMER, D.L. Consumption of solid food by suckling pigs: individual variation and relation to weight gain. Applied Animal Behaviour Science, v.32, p.139-155, 1991. 
PEDERSEN, L.J. et al. Suckling behaviour of piglets in relation to accessibility to the sow and the presence of foreign litters. Applied Animal Behaviour Science,v.58, p.267-279, 1998,

PÉREZ, M.P., et al. Effect of transport time on welfare and meat quality in pigs. Meat Science, v.61, n.4, p.425-433, 2002.

PETERSEN, V.; RÉCEN, B.; VESTERGAARD, K. Behaviour of sows and piglets during farrowing under free-range conditions. Applied Animal Behaviour Science, v.26, p.169-179, 1990.

PETERSEN, H.V.; VESTERGAARD, K.; JENSEN, P. Integration of piglets into social groups of free-ranging domestic pigs. Applied Animal Behaviour Science, v.23, p.223-236, 1989.

PRICE, E.0. Behavioral aspects of animal domestication. The Quarterly Review of Biology, v.59, p132, 1984.

PRUT, L.; BELZUNG, C. The open field as a paradigm to measure the effects of drugs on anxiety-like behaviors: a review. European Journal of Pharmacology, v.463, p.3-33, 2003.

RAMOS, E. M.; GOMIDE, L.A.M. Avaliação das carnes anormais: condições PSE e DFD. In: Avalição da qualidade de carne: fundamentos e metodologias. Viçosa: UFV. 2012. Cap. 10. p531-575.

RICHTER, S. H. et al. A glass full of optimism: Enrichment effects on cognitive bias in a rat model of depression. Cognitive, Affective, \& Behavioral Neuroscience, v.12, p.527-542, 2012.

ROCHA, L.M. et al. Hand-held lactate analyzer as a tool for the real-time measurement of physical fatigue before slaughter and pork quality prediction. Animal, p.1-8, 2014.

ROLLIN, B.E. The frankenstein syndrome: ethical and social issues in the genetic engineering of animals. Cambridge: Cambridge University Press, 1995, 241pp.

SCULLY, M. Dominion: The Power of Man, the Suffering of Animals, and the Call to Mercy. Nova York, EUA: St. Martin's Griffin, 2002. 448pp.

SERPELL, J. In the company of animals: a study of human-animal relationships. Nova lorque, EUA: Cambridge Univerity Press, 1996. 316pp.

SEYLE, H. The Story of the Adaptation Syndrome. Montreal: Acta Inc. 1952. 225pp.

SHAW, F.D.; TUME,R.K. The assessment of pre-slaughter and slaughter treatments of livestock by measurement of plasma constituents - A Review of Recent Work. Meat Science, v.32, p.311-329, 1992.

SOBESTIANSKY, J. Clínica e Patologia Suína. Goiânia: Goiânia, 1999, 464pp.

SORABJI, R. Animal Minds \& Human Morals. The Origins of the Western Debate. New York: Cornell University Press, 1995. 272pp.

SOMMAVILLA, R.; HÖTZEL, M.J.; DALLA COSTA, O.A. Piglets' weaning behavioural response is influenced by quality of human-animal interactions during suckling. Animal, v.4, p.1-6, 2011. 
SOUZA, A.S.; ZANELLA, A.J. Social isolation elicits deficits in the ability of newly weaned female piglets to recognise conspecifics Applied Animal Behaviour Science, v. 110, p.182-188, 2008.

SPINKA, M., Behaviour of pigs. In: Jensen, P. The Ethology of Domestic Animals: An Introductory Text. Wallingford, UK: CAB International, 2009. p. 177.

SPOOLDER H.; WAIBLINGER, S. Pigs and humans. In: MARCHANT-FORDE, J.N. The Welfare of Pig. West Lafayette: Springer. Cap. 7. p.2011-236, 2009.

STANGEL, G.; JENSEN, P. Behaviour of semi-naturally kept sows and piglets (except suckling) during 10 days post-partum. Applied Animal Behaviour Science, v.31, p.211-227, 1991.

STOLBA, A.; WOOD-GUSH, D.G.M. The behaviour of pigs in a semi-natural environment. Animal Production, v.48, p.419-425, 1989.

STUDNITZ, M.; JENSEN, M. B.; PEDERSEN, L. J. Why do pigs root and in what will they root? A review on the exploratory behaviour of pigs in relation to environmental enrichment. Applied Animal Behaviour Science, v.107, p.183-197, 2007.

TANIDA, H.; NAGANO, Y. The ability of miniature pigs to discriminate between a stranger and their familiar handler. Applied Animal Behaviour Science, v.56, p.149-159, 1998.

TANIDA. H. et al. Behavioral response to humans in individually handled weanling pigs. Applied Animal Behaviour Science, v.42, p.249-259, 1995.

THORNDIKE, E. L. Educational Psychology. New York, EUA: Teachers College of Columbia University, 1913.

TRUVE, J.; LEMEL, J. Timing and distance of natal dispersal for wild boar Sus scrofa in Sweden. Wildlife Biology, v.9, p.51-57, 2003.

VAN DER MEULEN J. et al. Increasing weaning age of piglets from 4 to 7 weeks reduces stress, increases post-weaning feed intake but does not improve intestinal functionality. Animal, v.4, p.1653-1661, 2010.

VAN DE WEERD, H.A.; DAY, J.E.L. A review of environmental enrichment for pigs housed in intensive housing systems Applied Animal Behaviour Science, v. 116, p. 1-20, 2009.

VIEUILLE, C., F. et al. Sow behaviour involved in the crushing of piglets in outdoor farrowing huts - A brief report. Applied Animal Behaviour Science, v.80, p.109-115, 2003.

VINKERS, C.H.; et al. The effect of stress on core and peripheral body temperature in humans. Stress, v.16. n.5, p.520-30, 2013.

VOLTAIRE. A Reply to Descartes. In: REGAN, T. SINGER, P. Animal Rights and Human Obligations. TNew Jersey: Prentice Hall, 1989.

WAIBLINGER, S. et al. Applied ethology: the basis for improved animal welfare in organics farm. In: VAARST, S. et al. Animal Health and Welfare in Organic Agriculture, Wallingford, UK: CAB, 2004. 
WARNER, R.D.; KAUFFMAN, R.G. GREASER, M.L. Muscle protein changes post mortem in relation to pork quality traits. Meat Science, v.45, n. 3, p.339-352, 1997.

WARRISS, P.D. Handling pigs immediately preslaughter - practical concerns and considerations for welfare and meat quality. Meat Focus International, v.3, p. 167-172, 1994.

WARRISS, P.D. et al. Effect of lairage time on levels of stress and meat quality in pigs. Animal Science, v.66, p.255-261, 1998.

WEARY D.M.; APPLEBY, M.; FRASER, D. Responses of piglets to early separation from the sow. Applied Animal Behaviour Science, v.63, p.289-300, 1999.

WEARY, D.M.; JASPERS J.; HÖTZEL, M.J. Understanding weaning distress. Applied Animal Behaviour Science, v.110, p.24-41. 2008.

WEARY, D.M.; LAWSON, G.L.; THOMPSON, B.K. Sows show stronger responses to isolation calls of piglets associated with greater levels of piglet need. Animal Behaviour, v.52, p.1247-1253, 1996.

WEILER, U. et al. Influence of sex and immunocastration on feed intake behavior, skatole and indole concentrations in adipose tissue of pigs. Animal, v.7, n.2, p.300-308, 2013.

WISMER-PEDERSEN, J. Water. In: PRICE, J.F., SCHWEIGERT, B.S. The Science of Meat and Meat Products. Connecticut, USA: Food and Nutrition Press. 1987. 584pp.

WOOD-GUSH, D.G.M.; BEILHARZ, R.G. The enrichment of a bare environment for animals in confined conditions. Applied Animal Ethology, v.10, p.209-217, 1983.

WOOD-GUSH, D.G.M.; VESTERGAARD, K. The seeking of novelty and its relation to play. Animal Behaviour, v.42, p.599-606, 1991.

WOROBEC E.K.; DUNCAN I.J.H.; WIDOWSKI T.M. The effects of weaning at 7, 14 and 28 days on piglet behaviour. Applied Animal Behaviour Science, v.62, p.173-182, 1999. 